\title{
THE MISSOURI SERIES OF THE PENNSYLVANIAN SYSTEM IN SOUTHWESTERN IOWA
}

JOHN L. TILTON 



\section{CONTENTS}

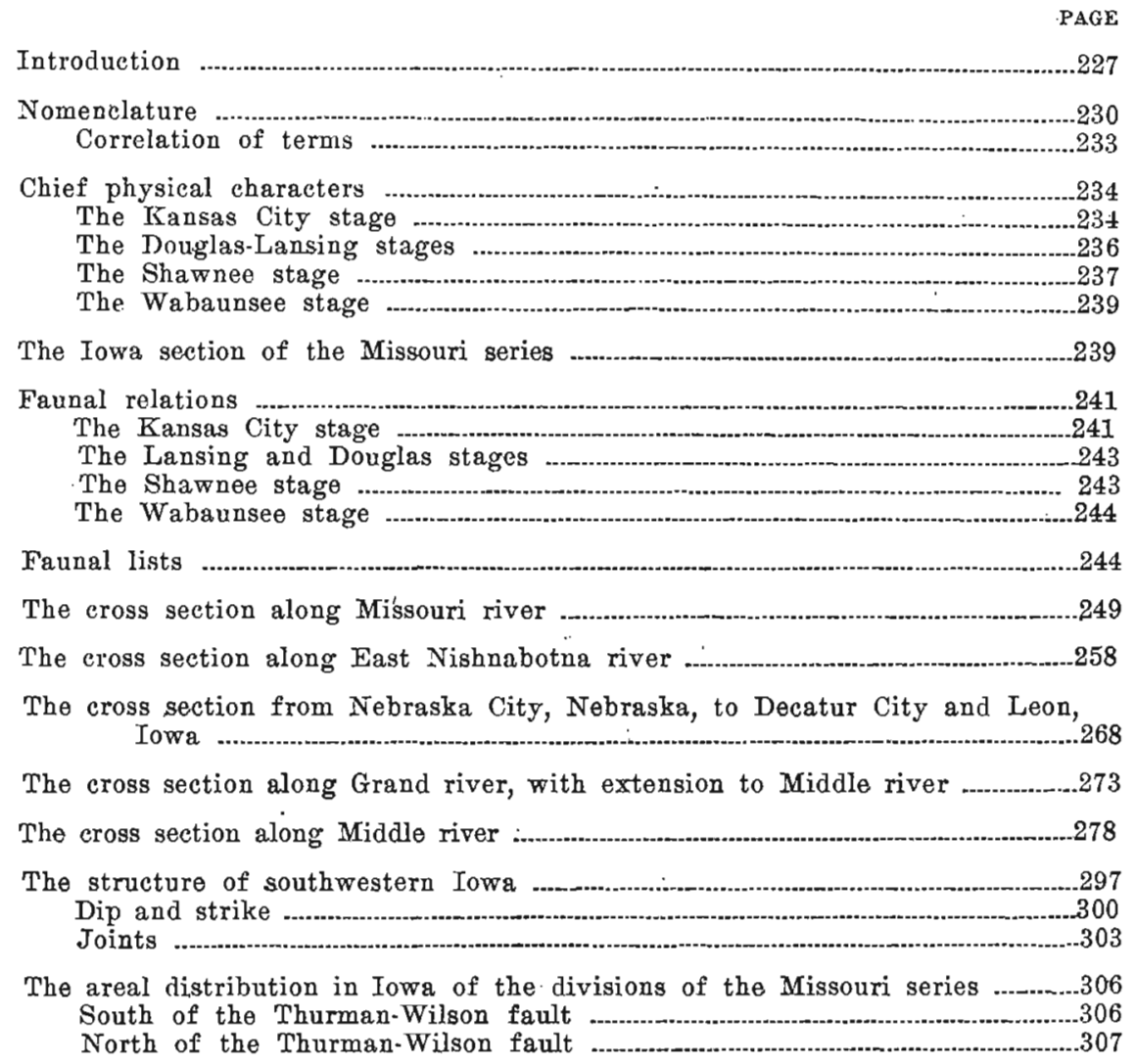




\section{ILLUSTRATIONS}

PLATES

XX. The cross section along Missouri river from Hamburg to Crescent; to face

XXI. Section across Adair county, south of the Thurman-Wilson fault, from Briscoe, Adams county, to the "Backbone", Madison county -

XXII. T:he cross section along East Nishnabotoa river fron Hamburg to

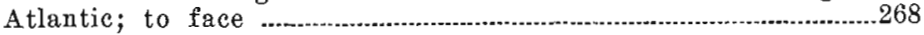

XXIII. The cross section from Nebraska City, Nebraska, to Decatur 'City and Leon, Iowa; to face

XXIV. The cross section along Grand river from Middle river to Davis

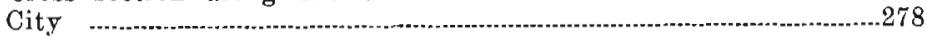

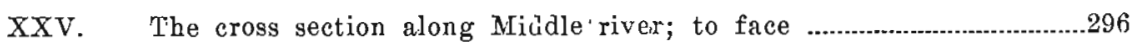

XXVI. Outline map giving locations of measurements of dip and strike

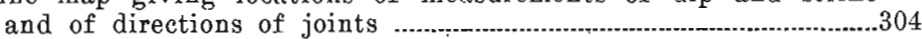

XXVII. Map of area near Stuart, showing distribution of strata

XXVIII. Map showing distribution of the Missouri series in southwestern Iowa; to face ........................................................................................314

K'IGURES

PAGE

38. The base of the DeKalb limestone above the Cherryvale shale near

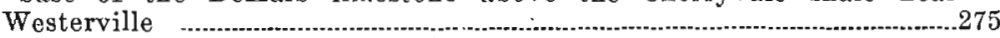

39. The top of the DeKalb limestone near Westerville

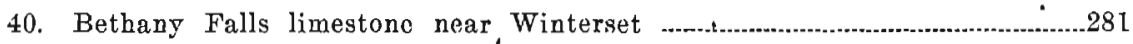

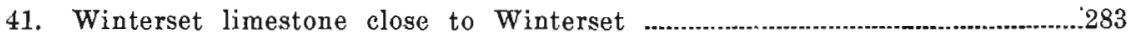

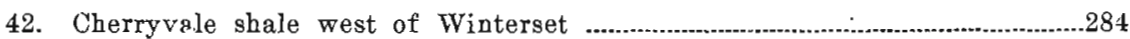

43. DeKalb limestone northwest of Osceola

44. Strata in a ravine, in Grand River township, Adair county

45. Section in a ravine in Harrison township, Adair county ................291

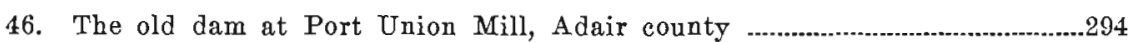

47. Deer Creek limestone below the dam at Port Union Mill .................294

48. Topeka and Deer creek limestones near Hawleyville, Page county .........295

49. Diagram of conditions across the fault plane, from Reno to Briscoe .....297

50. Winterset limestone northwest of Osceola ...................................................298

51. Winterset limestone at bridge west of Decatur City

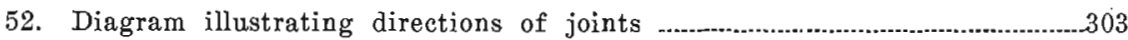

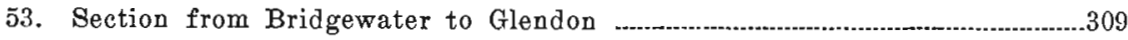

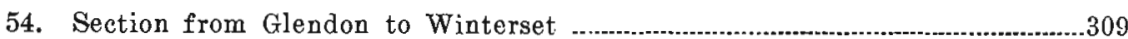




\title{
THE MISSOURI SERIES OF THE PENNSYLVANIAN SYSTEM IN SOUTHWESTERN IOWA
}

\author{
Introduction.
}

In presenting this paper the writer is impressed with the amount of detail that can now be used only in a general way. As the work progressed numerous problems have developed that he is reluctant to defer. He believes, however, that the general presentation here offered is sufficiently exact to be of immediate value in interpreting the Pennsylvanian of southwestern Iowa and in suggesting local problems that may be worked out to further increase the knowledge of the region.

From the date of the earliest geological map of Iowa to the present the Pennsylvanian of southwestern Iowa has been mapped as including what are now called Des Moines and Missouri strata, with no attempt to represent the distribution of the various subdivisions, except as St. John subdivided the Des Moines series. The limestone beds near Winterset and those of southeastern Nebraska attracted the attention of early geologists. The work of White, and later of Bain, Tilton and Leonard, in Madison, Guthrie, Dallas and Decatur counties, brought forth descriptions of :strata along the eastern margin of the Missouri series which Bain correlated with the Kansas City stage along Missouri river. Broadhead had made a complete section along Missouri river in Missouri, and this section was reviewed later by Hinds and Greene. The limestone of southeastern Nebraska had been visited by noted geologists, and was then carefully studied by Meek, and later a section was made in detail by Condra and Bengtson. These various reports connected the limestone of beds near Winterset with those in extreme southwestern Iowa by means of outcrops along Missouri river, but the great stretch of Pennsylvanian strata between still remained imperfectly known geologically. So deeply are the strata generally concealed beneath a mantle of thick glacial drift, and so similar are the beds of limestone and 
shale that such an observer as C. A. White ${ }^{1}$ was deceived into thinking that the beds of limestone near Lewis in Cass county were the same as those found at Winterset. To disclose relations in this large area E. H. Lonsdale was assigned Montgomery county (Vol. IV, Iowa Geol. Survey), while H. F. Bain studied Guthrie, Madison and Decatur counties and J. L. Tilton studied Madison county (Vols. VII and VIII, Iowa Geol. Survey). Then S. Calvin studied Page county, where George L. Smith had accumulated much local information, and J. A. Udden studied Pottawattamie county (Vol. XI, Iowa Geol. Survey). Udden then undertook the study of Mills and Fremont counties (Vol. XIII, Iowa Geol. Survey), and Calvin studied Ringgold and Taylor counties, but left the writing of the reports incomplete, to be finished by M. F. Arey (Vol. XXVII, Iowa Geol. Survey). To further aid in a general knowledge of the region the Survey published George L. Smith's paper on "The Carboniferous Section of Southwestern Iowa" (Vol. XIX, Iowa Geol. Survey). Later the study of Clarke and of Cass counties and a review of J. E. Gow's report of Adair county were assigned J. L. Tilton (Vol. XXVII, Iowa Geol. Survey). G. FY. Kay studied Union county and James H. Lees Adams county, the reports on which have not as yet been published.

It was as the study of Cass county progressed that the key to one of the main difficulties of the region was discovered. Not only was the region as a whole deeply covered with drift and with Dakota sandstone, leaving only occasional outcrops visible here and there, but a fault, the Thurman-Wilson fault; ${ }^{12}$ already noted near Missouri river, was discovered to cut clear

1C. A. White, Report on the Geological Survey of the State of Iowa; Vol. II, p. 6, 1870.

1"This displacement seems to have been first noticed by Professor Todd who described it in a paper entitled Folding of Carboniferous Strnta in Southwestern Iowa Iowa Acad. Science, Vol. I, pt. 1, p. 58, and later discussed it further in Some Variant Conclusions in Jnva Geology, Iowa Arad. Science, Vol. XIII, pp. 183, 184. Todd, howerer, did not recognize this as a true fault. He stated that 'The fold is quite sharp at Jones' Point (on the Nobraska side) and may. become a fault on the Iowa side." It ramained for George L. Smith to determine the presence of the fault and to locate and describe it accurately. This he did in his paper on The Carboniferous Section of Snuthwestern Iowa, Iowa Geol. Snrver, Vol. XIX. pp. 612. 647-649, 1908. Several years later Keyes mentioned a fault. called by him the Red Oak fanlt. which evidently is identical with the Thurman-Wilson fault of Smith, although the lo ralities he mentions are different from those named by Smith. See Iowa Acad. Science, Vol. XXTII, n. 106, 1916. Keyes has also mentioued the frult again in the June, 1922, number of the Pan-American Geologist.

Annther paper which discusses this fault is br Tilton and is entitled: The Tharman-Wilson Fault Through Southwestern Iowa and Its Bearing. Jour. Geol., Vol. XXVII, pp. 383-390, 1019. The fault is discussed also by Tilton in The Geology of Cass County, and The Geology nf Adair County, Iowa Geol. Survey, Vol. XXVII, pp. 209-216, 301-304. See also further discussion of this fault on page 251 of this volume. 
across the area, beneath the Dakota sandstone and the drift. It was not until the work on the present paper was in progress that the explanation of peculiar conditions along the entire northern border of the area was discovered: not only were strata removed by erosion from the north side of the fault, but the Kansas City stage was largely absent if it was present at all, the limestone at Stuart had previously been misinterpreted, and an overlap had brought the strata of the Lansing stage next to areas of the Des Mloines series.

In preparing this paper the writer has drawn freely from the carefully prepared published descriptions of strata and lists of fossils, believing them to be far more complete and accurate than any which he could prepare in two field seasons' study of so extensive an area. He has, however, visited the most important outcrops previously described, and many that are not important, and compared the printed descriptions of outcrops with the outcrops as they now exist. Where no credit is mentioned the writer makes use of his own descriptions. He wishes especially to acknowledge the assistance of Mr. Ivan Willis and Mr. Byron C. Hopper, two students whose activities contributed materially to the accumulation of data in the field. He also wishes to express appreciation of the careful oversight of James H. Lees, Ph.D., the Assistant State Geologist, while the report is in press.

The area covered in this report lies south of a line extending straight west from Des Moines to Missouri river, and west of a line from Des Moines straight south to the Iowa-Missouri state line. The area is thus approximately 8,820 square miles. The work is confined to the Missouri series though the subdivisions of the Des Moines series that lie next to the Missouri series are mentioned.

After presenting descriptions of the various members of the divisions of the Missouri series and lists of the fossils it is thought best to construct cross sections through the region as follows :

1st, Along Missouri river from Hamburg to Crescent, near Council Bluffs.

2d, Along Nishnabotna river, and across to Middle river.

3d, From Nebraska City, Nebraska, to Decatur City and Leon, Iowa. 
4th, Along Grand river with extension to Middle river.

5th, Along Middle river from Winterset to Stuart, connecting with the section from Leon and the one along Nishnabotna river.

The structure of the region as a whole is then described, and the areal distribution of the divisions is mapped.

\section{Nomenclature.}

The nomenclature discussed by Hinds and Greene in their report on the "Stratigraphy of the Pennsylvanian Series in Missouri," Missouri Bur. Mines, Bull. XIII, pages 27 and 115, which was previously adopted, with the exception of one term, for the reports on Clarke and Cass counties, is adopted for this report, with the exception of the same term, and the addition of subdivisions to the Wabaunsee stage. The Nebraska terms are also used wherever it is found desirable to introduce them.

The exception referred to is the term Drum limestone, instead of which the term De Kalb limestone will be used in this report. The term De Kalb was used by Bain ${ }^{2}$ in his report on Decatur county in 1897 to replace the descriptive term Fusulina limestone. This was six years prior to the use of the term Drum. ${ }^{3}$ Had Hinds and Greene been aware of the identity of the Drum and the De Kalb limestones undoubtedly they would have adopted the term De Kalb, for the De Kalb "agrees faunally and lithologically with that member (Drum) in northern Missouri," and is the next limestone immediately above the Cherryvale shale.

The Westerville limestone is here treated as thè equivalent of the De Kalb limestone, for near Westerville it occupies precisely the position described for the De Kalb limestone, the beds beneath along Sandy creek having the distinctive characteristics of the Cherryvale shale. Furthermore, in northern Decatur county a set of limestone beds which normally is fortyeight $t^{5}$ feet thick and lies above the Bethany Falls (Earlham)

2H. F. Bain, Geology of Decatur County; Iowa Geol. Surv:, Vol. VIII. p. 278.

3G. I. Adams, Stratigraphy and Paleontology of the Upper Carboniforous Rocks of Eastern Kansas: U. S. Geol. Survey, Bull. 211, p. 37, 1903.

4Hinds and Greene think that their "Cement City" bed "is possibly the same as the Westerville limestone of Iowa, but the correlation cannot be definitely made."

5H. F. Bain, Geology of Decatur County: Iowa Geol. Surver, Vol. VIII, p. 277. 
limestone does not exist. All the limestone that is now exposed at De Kalb has the characteristics of the Bethany Falls (Earlham) limestone, one point which Bain himself noted when remarking upon the absence of a Fusulina ${ }^{6}$ bed, so evident elsewhere in the limestone above the Cherryvale shale. The definition, however, does not apply to beds elsewhere, as near Winterset; but the term Westerville, supposed to apply to a limestone above the De Kalb, is dropped, except as it may be used in parentheses to call attention to a particular bed near Westerville.

The Wabaunsee ${ }^{\tau}$ stage is here divided into four members: Preston limestone, a shale, Tarkio limestone, and McKissick Grove shale.

The Preston ${ }^{8}$ limestone is the lowest limestone at Calvin's type section, number 1 in the description of rocks in sections 22 and 27 of Tarkio township, Page county. ${ }^{\circ}$ The base of the Preston limestone forms the base of the Wabaunsee stage.

The term Tarkio limestone is restricted to the uppermost beds of limestone, two or three in number, as numbers 5 to 8 in the type section referred to. No name is suggested for the shale and soft limestone between the two members: numbers 2 to 4 of the type section; the shale may be designated as the shale between the Preston and Tarkio limestone.

The term McKissick Grove was originally used to designate a location, as the "limestones and shales at McKissick's grove." 10 Condra and Bengtson applied the name as a formational name ${ }^{11}$ to those shales that are above the Tarkio limestone. Smith ${ }^{12}$ the following year also used the name as a formational name. The term is here applied to all of the strata that are found in Iowa above the Tarkio limestone. It begins with number 8 (the shale under the Nyman coal) and includes

\footnotetext{
BIdem, p. 278.

7C. S. Prosser, The Classification of the Upper Paleozoic Rocks of Central Kansas: Journal of Geology, Vol. III, p. 682, 1895.

condra and Bengtson. The Pennsplvanian Formations of Southeastern Nebraska: Nebraska Acad. Sci., Vol. 9, No. 2, p. 28, Feb., 1915.

DIowa Geol, Survey, Vol. XI, p. 430.

10G. J. Smith, The Carboniferous Section of Southwestern Iowa: Iowa Geol. Survey, Vol. $\mathrm{XIX}, \mathrm{p} .639$.

11The Pennsylvanian. Formations of Southerstern Nebraska, p. 28, 1915.

12G. I. Smith, Contributions to the Goology of Southwestern Iowa: Proc. Iowa Acad. Sci., Vol. XXIII, p. 86, 1916.
} 
all the numbers above in Smith's description of the limestones and shales at McKissick grove. ${ }^{13}$

The accompanying table expresses a correlation of terms that may be found in use. The second table is a synoptical table of formations as the names are used in this report.

13G. L. Smith, The Carboniferous Section of Southwestern Iowa: Iowa Geol. Survey, Vol. XIX, p. 639. 


\section{CORRELATION OF TERMS.}

Hinds aNd Greene Keyes, Vol. 7, STRAT, PENN. SERIES MISSOURI

Proc. Iowa ACAD, SOI.

FEET

$100+$ Wabaunsee Tarkio ls. 350-475 Shawnee Scranton sh.

Howard ls.

Severy sh.

Cottonwood ls.

Atchison sh.

Osage sh.

Topeka ls.

Topeka ls.

Calhoun sh.

Deer Creek ls. Calhoun sh.

Lecompton is.

Tecumseh

Lecompton ls.

Kanwaka sh 200-300 Douglas

Oread ls.

Lawrence sh

Iatan ls.

Weston sh.

100-140 Lansing

Stanton ls.

Villas sh.

Plattsburg ls.

Lane sh.

200-225 Kansas City

Iola ls.

Chanute sh.

Drum ls.

Cherryvale sh.

Winterset 1s.

Galesburg sh.

Bethany Falls ls.

Ladore sh.

Hertha ls.

$950-1140$

Plattsmouth Is.

Andrew sh.

Iatan ls.

Weston sh.

Stanton ls.

Parkville sh.

Iola ls.

Thayer sh.

Bethany ls.
Condra and Bengtson, G. L. SMith, Vol. XIX,

Nebraska Section Iowa GeOlogioal

SURVEY

Other Names

No.

FEET

$\begin{aligned} 18 & \text { Tarkio } \\ 17 & \text { Preston } \\ 16 & \text { Fargo } \\ 15 & \text { Burlingamo } \\ 14 & \text { Rulo } \\ 13 & \text { Ashland } \\ 12 & \text { Southbend } \\ 11 & \text { Irouisville } \\ 10 & \text { Union } \\ 9 & \text { Meadow }\end{aligned}$

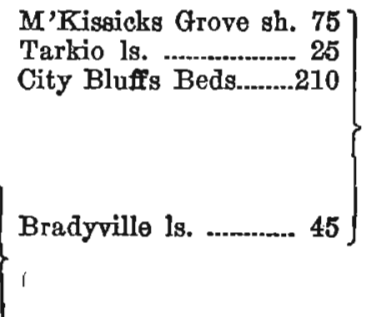

Admire sh.

Barclay, Emporia ls.

Willard sh.

Atchison sh.

$$
\text { ] }
$$

8. Forbes

Forbes sh.

18

Hertford 18.

7 Cedar Creek

Platte sh.

5 Plattsmouth

Plattsmouth 1s. ....... 40

4 Weeping Water

3 Oreopolis

Andrew sh.

.172

Iatan ls.

Wheton sh 76

Plattsburg ls. ............ 19

Stennett, Nodaway

Parkville sh. (in-
cluding Iola)

aluding Iola) _....... 22

Bethany ls

$\{$ coroy sh.

Strawn, Kickapoo, Ottawa

Piqua, Garnett, Burling ton, Cave Rock
Westerville 1s., Cement City Is., DeKalb, Fusulina, Dennis

Earlham, Mound Valley

Fragmental ls. 
SYNOPTICAL TABLE OF FORMATIONS.

\begin{tabular}{|c|c|c|c|c|c|c|}
\hline Grou? & SySTEN. & Series & STAGE & SUBSTAGE & $\begin{array}{l}\text { CHARACTER } \\
\text { OF ROCKS }\end{array}$ & $\begin{array}{l}\text { NEBRASKA } \\
\text { TERMS: FOR } \\
\text { COMPARISON }\end{array}$ \\
\hline \multirow{31}{*}{ Paleozoic } & \multirow{31}{*}{$\begin{array}{l}\text { Pennsyl- } \\
\text { vanian }\end{array}$} & \multirow{31}{*}{ Missouri } & \multirow{4}{*}{$\begin{array}{c}\text { Wabaun- } \\
\text { see }\end{array}$} & $\begin{array}{c}\text { MeKissick } \\
\text { Grove }\end{array}$ & Shale & \\
\hline & & & & Tarkio & Limestono & Tarkio \\
\hline & & & & & Shale & \\
\hline & & & & Preston & Limestone & Preston \\
\hline & & & \multirow{9}{*}{ Shawnee } & Seranton & Shale & $\begin{array}{l}\text { Fargo } \\
\text { Burlingame } \\
\text { Rulo }\end{array}$ \\
\hline & & & & Howard & Limestone & $\begin{array}{l}\text { Ashland } \\
\text { Southbend }\end{array}$ \\
\hline & & & & Severy & $\begin{array}{l}\text { Shale; Nod- } \\
\text { away coal }\end{array}$ & $\begin{array}{l}\text { Louisville } \\
\text { Union }\end{array}$ \\
\hline & & & & Topeka & Limestone & Meadow \\
\hline & & & & Calhoun & Shale & \\
\hline & & & & Deer Creek & Limestone & Forbes \\
\hline & & & & Tecumseh & Shale & \\
\hline & & & & Lecompton & Limestone & $\begin{array}{l}\text { Cedar Creek } \\
\text { Cullom }\end{array}$ \\
\hline & & & & Kanwaka & Shale & \\
\hline & & & \multirow{5}{*}{ Douglas } & Oread & Limestone & Plattsmouth \\
\hline & & & & & & $\begin{array}{l}\text { Weeping } \\
\text { Water }\end{array}$ \\
\hline & & & & isawrence & Shale & Oreopolis \\
\hline & & & & Iatan & Limestone & Sturm \\
\hline & & & & Veston & Shale & Nehawka \\
\hline & & & \multirow{4}{*}{ Lansing } & Stanton & Limestone & \\
\hline & & & & Vilas & Shale & \\
\hline & & & & Plattsburg & Limeston $\theta$ & \\
\hline & & & & Lane & Shale & \\
\hline & & & \multirow{9}{*}{$\begin{array}{c}\text { Kansas } \\
\text { City }\end{array}$} & [ola & Limestone & \\
\hline & & & & Chanute & Shale & \\
\hline & & & & De Kalb & Limestone & \\
\hline & & & & Cherryvale & Shale & \\
\hline & & & & Winterset & Limestone & \\
\hline & & & & Galesburg & Shale & \\
\hline & & & & $\begin{array}{l}\text { Bethany } \\
\text { Faills }\end{array}$ & Limestone & \\
\hline & & & & Ladore & Shale & \\
\hline & & & & Hertha & 'Ijimestone & \\
\hline
\end{tabular}

\section{Chief Physical Characters.}

The Kansas City Stage.-The thicknesses of the various members are as follows, where these are not diminished by erosion: 


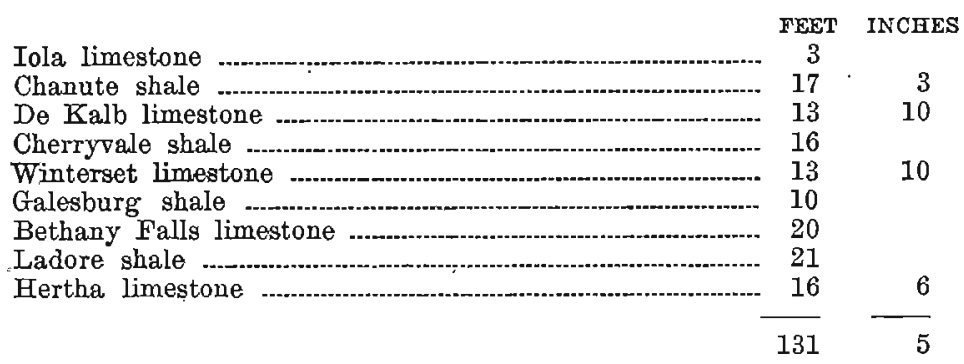

In the description of local sections used in plotting the cross sections the section at Winterset may be considered as a standard.

The Hertha limestone is in two portions with shale between. It contains an abundance of Composita subtilita and but few of the other usual Pennsylvanian fossils. While it is so fragmental as to have merited that name as a descriptive term, it is not the only fragmental limestone in the stage. The Bethany Falls and the Winterset limestone beds are each fragmental at the top, but are not fragmental throughout as is the Hertha.

The Ladore shale has a stratum eight inches thick of dark limestone four feet below its upper limit.

The Bethany Falls limestone is now the chief escarpment maker along ravines cut in the eastern front of the strata of the Missouri series. The thickest beds are near the base.

The Galesburg shale is gray in its upper and lower portions and black through the center.

The Winterset limestone is generally in two beds with the thicker bed at the top.

The Cherryvale shale has near its center a blue limestone separated into three parts by bands of shale the lower of which is very thin. This horizon is the most distinctly marked by fossils of any in the Kansas City stage. This limestone is a Myalina horizon, with Orthotetes crassus and Chonetes verneuilianus in abundance. In the shale beneath the blue limestone the Chonetes are. so numerous as to constitute thin beds of limestone.

The De Kalb limestone contains numerous small Fusulina.in a matrix of fine calcareous material. In the western part of Madison county it is conspicuous in the low escarpment that 
extends along the east side of Middle river south of Webster where it shows its greatest thickness. The top, where the full thickness is present, is made up chiefly of calcareous pebbles, and is somewhat arenaceous. The lower five feet is rich in large Fusulinas.

The Chanute shale is thickest along Brushy creek neat the west line of Madison county. The lower portion consists of fossiliferous limestone and calcareous shale, and the upper half of drab, red and green shale.

The Iola limestone member includes the next two limestones above the colored shale, with the sixteen-inch bed of shale between them. The lower bed is somewhat fragmental; the upper bed is fossiliferous.

The Douglas-Lansing Stages.-From the top of the Iola limestone, or, better still, from the top of the De Kalb limestone, to the base of the Oread limestone (a definite horizon) there is a succession of limestones and shales that are diffcult of assignment to the divisions as recognized in Missouri and Nebraska. The beds outcrop in ravines along the southwest side of Middle river from two miles south of Webster to the central part of Harrison township, Adair county. The strata may be met within a distance of two miles, and the vertical difference in elevation is only forty-nine feet, which is distributed as follows:

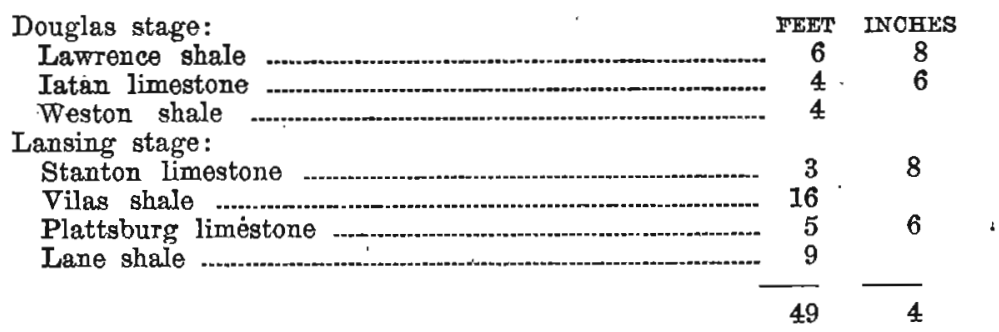

In Missouri these beds, up to the thickest beds of the Oread limestone (Broadhead's number 150), measure about 260 feet in thickness for the Douglas stage and about 127 feet for the Lansing stage. In Missouri the Plattsburg limestone member is 18 feet thick; in central Iowa it is 5 feet, 6 inches thick. In Missouri the Stanton limestone member contains 23 feet of limestone. In the Iowa region the Stanton limestone is but 
3 feet, 8 inches thick. ${ }^{14}$ The shaly members also are much thinner in Iowa than in Missouri.

The Nebraska section recognizes four groups of limestone beneath the Oread (Plattsmouth) limestone, referring them to the Lawrence shale:

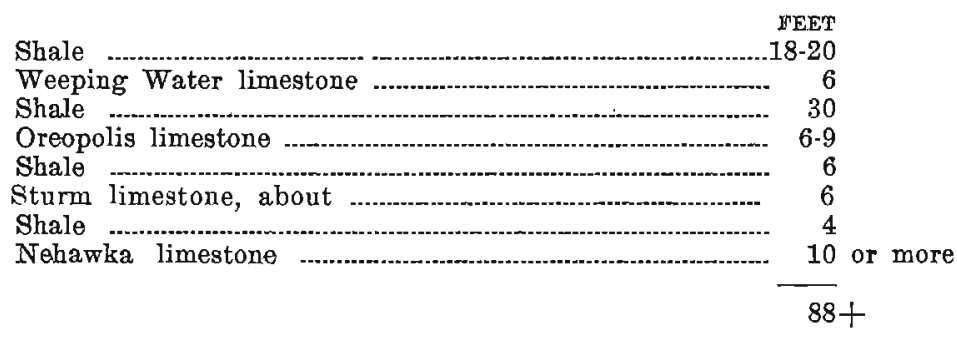

It is evident that the topmost shale in this section should be referred to the Lawrence shale, as the term is used in Missouri, and that the groupings of the limestone members would make the Nehawka correspond to the Iola limestone. It is clear that both limestone and shaly members in this general horizon are much thinner in eastern Adair than they are in southeastern Nebraska.

The Shawnee Stage.-The various thicknesses of the members of the Shawnee stage are as follows:

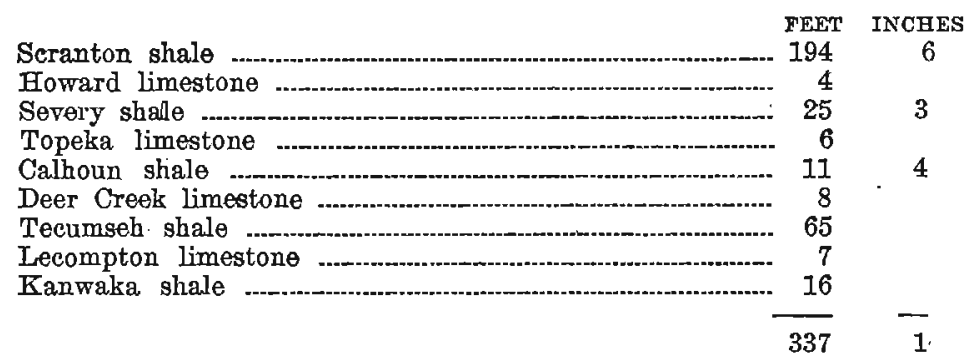

The thicknesses given for the very thick shales in the above list are obtained from the record of the Clarinda diamond drill hole, and not from measurement of outcrops, for they do not outcrop in such a way that measurement of the thickness is possible.

The portion of the Oread limestone that is characterized by "millions of Fusulina" closely packed together, as Meek ${ }^{15}$ de-

\footnotetext{
14The comparison is based on pages 113 and 114 of Hinds and Greene's Stratigraphy of the Pennsylvanian Series in Missouri.

15F. B. Meek, Report on the Paleontology of Eastern Nebraska, pp. 92-93.
} 
scribed the beds near Plattsmouth fifty years ago, has the same characteristics where it outcrops at Riverview Park north of Red Oak and in Harrison township in eastern Adair. This makes a very good horizon from which to work upward in the vicinity of Stennett in an endeavor to correlate those beds with the corresponding beds in eastern Nebraska. The sequence can be traced without difficulty along the road and then up the ravine north of Stennett, from the Oread to and including the Severy (Louisville limestone), except that the Lecompton (Cullom) limestone is beneath the river deposits. The thicknesses of these groups of strata are as follows, each including the shale above it:

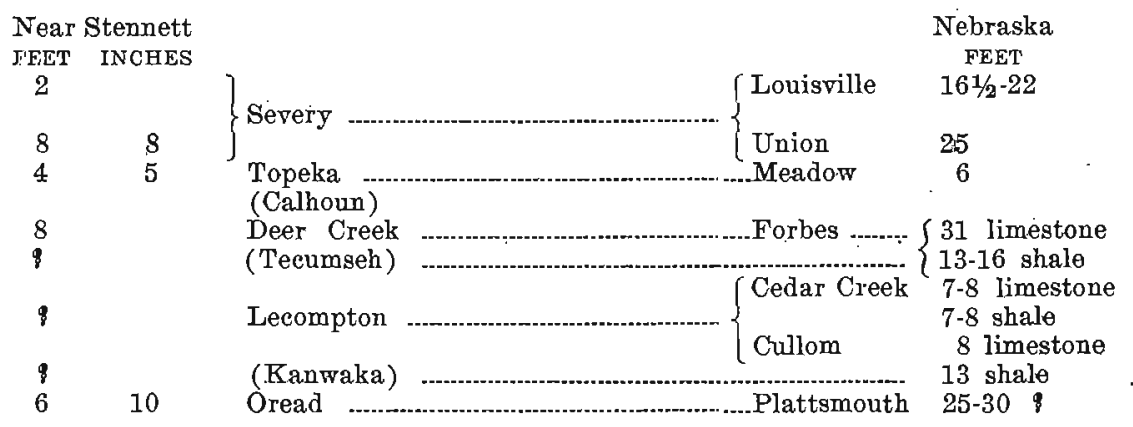

Here also it is evident that the various members thin out toward the northeast.

The Deer Creek limestone is recognized also farther southeast on the south side of the Thurman-Wilson fault. ${ }^{15 a}$ The uppermost limestone that is exposed at Hawleyville evidently is the Topeka (Meadow) limestone. The other Nebraska members, Union to Ashland, are portions of what has been called Braddyville limestone in Iowa by Smith, and the Severy shale, Howard limestone, and Scranton shale in Missouri. The Nodaway coal seam forms a marked horizon in the upper part of the Severy shale. A gray shale immediately underlies the coal and the Howard limestone is about four feet above it.

The Cullom and Cedar Creek limestones that are in the valley northwest of Rivierview Park, Red Oak, and near Stennett correspond to the Lecompton limestone of Missouri, the shale above these two limestories corresponds to the Tecumseh shale,

$1^{\text {n See note }} 1^{\text {n }}$ on page 228 . 
and that below them and extending down to the Oread limestone, is the Kanwaka shale.

The Scranton shale of the Missouri survey extends from the top of the Howard limestone to the base of the Preston limestone. The Rulo, Burlingame and Fargo limestones of Nebraska may be considered as parts of the Scranton shale. Except the Fargo they have not been recognized as distinct beds in Towa. The Fargo appears at the base of the McKissick grove section, and at an outcrop a mile southwest of Red Oak.

The Wabaunsee Stage.-The four members of the Wabaunsee stage as here recognized have the following thicknesses in Iowa:

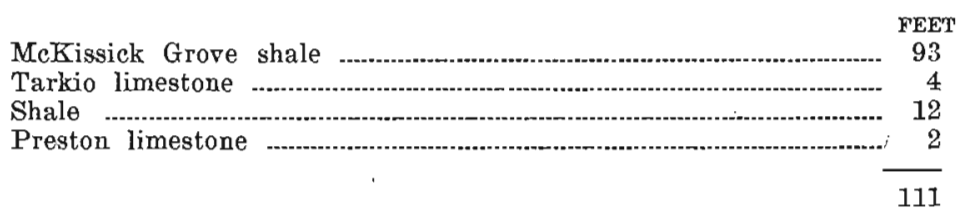

The Preston limestone member is essentially a single ledge. The Tarkio is a blue hard limestone at the base and a Fusulina limestone at the top. The shale between the Preston and Tarkio limestones is an ordinary gray shale including a thin bed of light colored limestone. The McKKissick Grove shale is increasingly arenaceous and micaceous toward the top, and also toward the south into Missouri.

The above terminology avoids the use of the terms Osage shale, Platte shale, Braddyville limestone, City Bluffs shale and Atchison shale, which have been variously used to include several members of the upper part of the Shawnee stage.

THE IOWA SECTION OF THE MISSOURI SERIES.

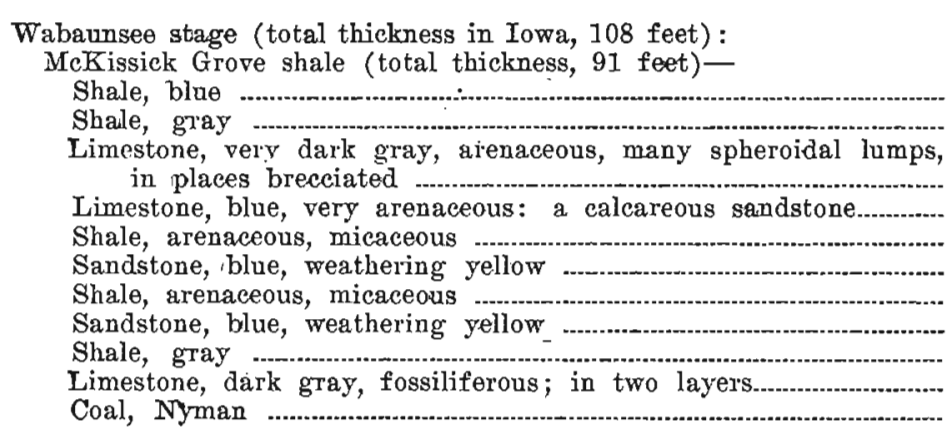

FEET INCHES 12 8 1 1 3 
Shale, yellow and blue

FEET INCHES

Limestone, gray, fossiliferous

31

Shale, dark gray

Limestone, very dark gray

Tarkio limestone-

Limestone, weathering brown; in two or three layers ..............

Shale, not named-

Shale, gray, between Tarkio and Preston limestones ..................... 12

Preston limestone-

Limestone, dark gray

Shawnee stage (total thickness, 337 feet, 1 inch):

Scranton shale-

Shale, variously colored; from estimate by Smith ......................... 194

Howard limestone-

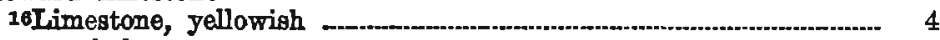

Severy shale-

16Shale; includes Nodaway coal, Louisville limestone (2 feet), Union limestone and shale above it (8 feet, 8 inches) .......

Topeka limestone

Limestone, near Stennett

Calhoun shale

Shale, near Stennett

6 12

Deer Creek limestone-

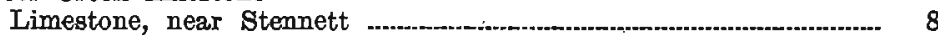

Tecumseh shale-

16 Shaile

Lecompton limestone-

16Limestone

Kanwaka shale-

16 Shale

Douglas stage (total thickness, 25 feet, 7 inches):

Oread limestome (at Riverview Park, Red Oak) (thickness, 10 feet, 5 inches)-

Limestone, upper part decomposed; fossiliferous; many Fusulinas

Shale

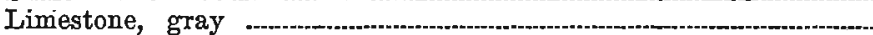

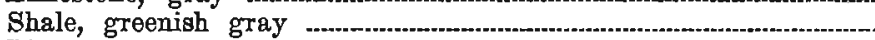

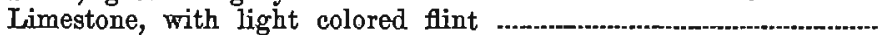

Shale

Limestone, gray

(Below this plane the limestone is full of Fusulina.)

Limestone, gray, in three parts

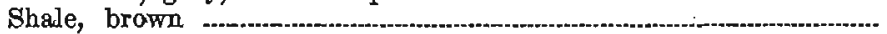

Limestone, shaly below .......................................................................

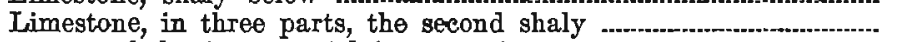

Lawrence shale (eastern Adair county)-

Shale, gray, fossiliferous

Iatan limestone ( thickness, 4 feet, 6 inches)-

Limestone, dark gray, fossiliferous

Shale, ealcareous

Limestone, gray and dark, weathers brown, fossiliferous...........

Weston shale

Shale, gray above and below, black in center

Lansing stage (total thickness, 36 feet, 1 inch):

Stanton limestone (thickness, 3 feet, 8 inches)-

Limestone, gray, dense, fossiliferous

Shale, blue

Limestone, dark gray 5

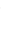

10The total thickness is from the record of the Clarinda Diamond Drill hole, Iowa Geol. Surver, Vol. XIX, page 618 . 
Vilas shale-

Shale, gray and green, with iron concretions at top

Plattsburg limestone-

Limestone, lower portion dense, gray ...........................................

Lane shale (thiekness, 6 feet, 11 inches)-

Shale, green, clayey

Limestone, greenish, lower half shaly

Shale, greenish

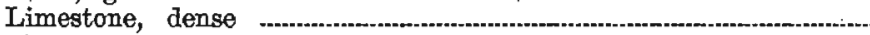

Shale, gray, arenaceous, micaceous and calcareous

Kansas City stage (total thickness, 131 feet, 5 inches):

Iola limestone (thickness, 3 feet) -

Limestone, very fossiliferous

Shale, gray above, dark below

Limestone, somewhat fragmental

Chanute shale (thickness, 17 feet, 3 inches)-

Șhale, drab

Shale, red

Shale, green, calearreous

Limestone, bluish, somewhat fragmental above

Shale, gray, several nodular calcareous layers

DeKalb limestone (thickness, 13 feet, 10 inches) -

Limestone, of calcareous pebbles, upper part slightly arenaceous

Limestione, gray, thin layers above, thick below, fossiliferous.-...

Cherryvale shale-

Shale, gray above and in lower portion, three layers of blue limestone between; limestone and all below very fossiliferous

Winterset limestone (thickness, 13 feet, 10 inches) -

Limestone, gray, fragmental in upper portion.

Limestone, gray, very resistant ledge; with chert

Limestone, gray

Shale, gray, argillaceous

Limestone, gray

Limestone, gray; partings of shale

Galesburg shale (thickness, 10 feet) -

Shale, gray, argillaceous

Shale, black

Shale, gray, argillaceous above, calcareous below

Bethany. Falls limestone-

Limestone, gray, in bods from 1 foot to 1 foot, 6 inches thick; top portion fragmental; fossiliferous

Ladore shale (thickness, 21 feet)-

Shale, gray, argillaceous

Shale, black (seam of coal elsewhere)

Limestione, dark blue

Shale, calcareous in places

Limestone, gray

Shale, gray, argillaceous.

Limestone, gray

Shale, gray, argillaceous

Hertha limestone (thickness, 16 feet, 6 inches)-

Limestone, gray

Shale, gray, argillaceous

Limestone, gray, very fragmental

Total thickness of Missouri stage

Faunal Relations.

The Kansas City Stage.-The first faunal unit includes the whole of the Kansas City stage, though the fauna of the upper- 
most beds presents a contrast to that found in the lowest beds. It has long been recognized that the Kansas City stage in Iowa does not contain Chonetes mesolobus but has instead Chonetes verneuilianus; that it does not contain Marginifera muricata but does contain Marginifera longispina, and that the fauna in general changes from that of a sandy shore and of brackish water sandstone and shale (Des Moines series) to that of limestone and shale of a more open sea. Under such conditions an off-shore fauna migrated back and forth with little significant change. The different limestones must be recognized in the field largely by the sequence in their beds and by their relation to the shales above and below, features which have already been included in the descriptions of the various members of the Missouri series, and will be included also in the descriptions accompanying the transverse sections across the region. The faunal lists follow these comments.

The Hertha limestone has Composita subtilita as a specially characteristic form. ${ }^{17}$ Near St. Charles there is an isolated ledge of Chaetetes milleporaceous, that seems to be held over from the Des Moines series, but it is not found elsewhere.

The Bethany Falls limestone has, along with the usial assemblage of fossils, an occasional Phillipsia in the shaly partings, but they are too rare to be of use in distinguishing these beds from other beds near at hand-in which they have not been found.

The Winterset limestone has in the shaly parting between the two main beds of limestone a bed of Composita subtilita. of especially large forms.

'The Cherryvale shale presents the most distinctive faunal horizon to be found in the Kansas City stage. There is nothing like it to be found elsewhere in the Missouri series, the nearest approach being in the Deer Creek. Chom:tes verneuilianus, abundantly distributed through the shale in the lower half of the member, is so abundant in places as to constitute thin beds of shaly limestone. The three thin beds of biue limestone about midway in the member comprise a Myalina

17The long list of fossils that Bain gives from the limestone near Stuart, Iowa, is not of fossils from the Hertha limestone, but from a bed deep down in the Des Moines series (Henrietta): H. F. Bain, Geology of Guthrie County: Iowa Geol. Survey, Vol. VII, pp. 447-448. Seo etta): H. F. Bain, Geology of Guthrie County: Iowa Geol. Survey, Vol. VII, pp. 447-448. See
John L. Tilton, The Strata near Stuart, Iowa: Bull. Geol. Soc. America, Vol 33, p. 153, 1922. 
horizon, containing two species, swallovi and subquadrata. Along with these are numerous Orthotetes (Derbya) crissus and an occasional Meekella striatocostata.

While the lower part of the De Kalb limestone was originally called.a Fusulina limestone the fusulinids are not always present in abundance, and are small in size. The occasional echinoid spines, the fusilinids and the Bryozoa relate the upper beds of the De Kalb to the Iola, and the relative abuudance of these forms helps distinguish the upper members from the lower members of the stage.

The Lansing Stage and the Douglas Stage.-The laurial unit recognized by Beede and Rogers includes both the Juausing and the Douglas stages. The fauna marks an advancing open sea that reached its culmination when the Oroad limestone was laid down. A detailed study of the thin beds below the Oread may lead to further faunal differentiations, as the beds are very fossiliferous but not easily accessible. It is here that Enteletes hemiplicata and Chonetes granulifer are first found, differentiating the Lansing from the Kansas City stage. Beede mentions the presence of Rhipidomella pecosi and Derbya bennetti, and calls attention to a form with a more costate habit to which he gives the name Marginifera wabashensis. Meekella striatocostata, which he did not find below this horizon in the Missouri collections, is occasionally found in the Winterset limestone at Winterset. Beede further recognizes the introduction of the following in the Douglas fauna: Chonetes geinitzianus, Marginifera lassellensis and Tegulifera armata.

In the Oread limestone there is such a remarkable assemblage of large Fusulina closely packed together as to distinguish this horizon from all others. This characteristic is a widespread one, as noticeable in eastern Adair county, Cass county and at Riverview Park in Montgomery county as at the mouth of the Platte river in Nebraska, where $\mathbf{M e e k}^{18}$ èmphasized the abundance of it.

The Shawnee Stage.-The fauna of the Shawnee stage centers in that of the Deer Creek member, beds of which outcrop north of Stennett and at Hawleyville. Even here distinctions

18F. B. Meek, Report on the Paleontology of Eastern Nebraska: p. 93, 1872. 
find their chief emphasis in the associated character of the strata. The black chert contains white Fusulina-excellent microscopic material; and the limestone contains such an abundance of echinoid spines that they become a characteristic form. Greene notes that the limestone over the Nodaway coal seems largely made up of Ostracods. The central part of the Scranton shale, as exposed at "City Bluffs" a few miles south of the state line, is marked by a bed of Aviculopecten.

The Wabaunsee Stage.-Fere also the important distinctions are physical rather than faunal. The lower portion contains the Preston and Tarkio limestones with the faunas listed below. The upper part of the McKissick Grove shale is increasingly arenaceous and micaceous toward the top, with fauna as given below. While the character of the deposits indicates a return of shallow water conditions that according to reports elsewhere were widespread, the faunal relations do not depart widely from those in the lower part of the stage. The presence of mica, though it is not a fossil, is especially noteworthy.

FAONAL IISTS

THE WABAUNSEE STAGE.

MoKissiclo Grove shale.18

Upper limestone fauna

Fusulina cylindrica (secalica)

Lophophyllum profundum.

Ceriocrinus hemisphericus

Fenestella perelegans

Fistulipora nodullifera

Rhombopora lepidodendroides

Ambocoelia planoconvexa

Chonetes geinitzianus

Chonetes granulifer

Composita subtilita

Hustedia mormoni

Marginifera wabashensis

Productus cora

Productus semireticulatus

Pugnax uta

Spirifer cameratus

Allorisma terminale

Aviculopecten occidentalis

Aviculopecten providencensis

Edmondia nebrascensis

Myalina swallovi

Bucanopsis marcouanus

Euphemus carbonariug
Cap rock to Nyman coal Fusulina cylindrica (secalica)

Crinoid stems

Rhombopora lepidodendroides

Ambocoelia planoconvexa

Chonetes granulifer

Enteletes hemiplicata

Marginifera longispina

Orthotetes crassus

Productus costatis

Productus punetatus

Productus semireticulatus

Pugnax uta

Composita subtilita

Spirifer cameratus

Edmondia nebrascensis

Macrodon tenuistriatis

Myalina subquadrata

Nucula

Schizodus 9

Euomphalus catilloides

Phanerotrems grayvillensis

Pleurotomaria perhumerosa

Griffithides scitula

19George L. Smith, Contributions to the Geology of Southwestern Iowa: Proc. Iowa Acad. Sci.: Vol. XXIII, pp. 86-87, 1916. J. A. Udden, Geology of Mills and Fremont Counties: Iowg Geol. Survey, Vol. XIII, p. 152 (Section XIX, number 16 for Cap Rock of Nyman Coal). 
Lower shale fonuna

Fusulina cylindrica (secalica)

Lophophyllum profundum

Ceriocrinus hemisphericus

Fistulipora nodulifera

Rhombopora lepidodendroides

Ambocoelia planoconvexa

Chonetes geinitzianus

Chonetes granulifer

Composita subtilita

Dielasma bovidens

Enteletes hemiplicata

Hustedia mormoni

Meekella striatocostata

Orthotetes crassus

Productus cora

Productus costatus

Productus (Pustula) nebrascensis

Productus punctatus

Productus semireticulatus

Pugnax uta

Rhipidomella pecosi

Spirifer cameratus

Avicullopecten occidentalis

Aviculopecten whitei

Edmondia nebrascensis

Entolium a viculatum

Leda bellistriata

Myalina perattenuata

Myalina subquadrata

Myalina swallovi

Parallelodon wheeleri

Aclisina stevensana

Bucanopsis montfortiana

Euomphalus catilloides

Euphemus carbonarius

Phanerotrema grayvillensis

Tarkio limestone.20

Fusulina cylindrica

Zeacrinus (numerous segments')

Rhombopora lepidodendroides

Ambocoelia plarioconvexa
Chonetes geinitzianus

Chonetes granulifer

Chonetes verneuilianus

Composita subtilita

Enteletes hemiplicata

Meekella striatocostata

Orthotetes crassus

Productus cora

Productus costatus

Productus (Marginifera) longispinus

Productus (Pustula) nebirascensis

Productus pertenuis

Productus semireticulatus

Pugnax uta

Spirifer cameratus

Spiriferina kentuckiensis

Allorisma subcuneata

Allorisma terminale

Avicula longa

Aviculopecten whitei

Aviculopinna americana

Entolium aviculatum

Myalina kansasensis

Myalina perattenuata

Myalina subquadrata

Myalina swadlovi

Bellerophon percarinatus

Bucanopsis montfortiana

Naticopsis altonensis

Orthonema subeniatum

'Phanerotrema grayvillensis

Spherodoma primigenia

Platyceras parvum

Orthoceras rushense

Phillipsia major

Shate between Tarkio and Preston

limestones.

No fossils are reported.

Preston limestone.

Fossil fragments arè found, bùt no species are recognized.

THE SHAWNEE STAGE.

Scranton shale.21

Zeacrinus (plates)

Fistulipora

Rhombopora

Ambocoelia planoconvexa

Productus cora

Productus (Marginifera) longispinus

Productus (Pustula) nebrascensis

Productus semireticulatus
Spiriferina kentuckiensis Straparollus catilloides Scranton shale and Howard limèstone.22 Fusulina cylindrica. Lophophyllum profundum Lophophyllum distortum Ceriocrinus hemisphericus Erisocrinus typus Eupachycrinus tuberculàtus

20This is a conbination of three lists reported as follows: Samuel Calvin, Geology of Page County: Towa Geol. Survey, Vol. XI, p. 432. Georgd L. Smith, Carboniferous Section of Southwestern Iowa: Iowa Geol. Survey, Vol. XIX, p: 683; and The Paleontology and Stratigraphy of the Upper Carboniferous of Iowa: Proc. Iowa. Acad. Sci., Vol. XXII, p. 281. J. graphy of the Upper Carboniferous of lowa: Proc. Iowa. Acad. Sci., Vol. XXII, p. 281. J. (Section XVI), and p. 154 (Section XIX, number 6).

21Samuel Calvin, Geology of Page County: Iowa Geol. Survey, Vol. XI, p. 429.

22George L. Smith; The Paleontology and Stratigraphy of the Upper Carboniferous of Iowa: Proc. Iowa Acad. Sci., Vol, XXII, p. 281; Carboniferous Section of Sonthwestern Iowa: Iowa Geol. Survey, Vol. XIX, p. 638. J. A. Udden, Geology of Mills and Fremont Counties: Iowa Geol. Survey, Vol. XIIr, p. 146 (No. 16), p. 147 (No. 9). 
Hydreionocrinus acanthoporus Hydreionocrinus mucrospinus Serpula insista

Fenestella perelegans

Fistulipora nodulifera

Pinnatopora trilineata

Polypora crassa

Polypora elliptica

Polypora submarginata

Rhombopora lepidodendroides

Septopora biserialis

Stenopora carbonaria

Ambocoelia planoconvexa

Chonetes geinitzianus

Chonetes granulifer

Chonetes variolatus

Composita subtilita

Dielasma bovidens

Enteletes hemiplicata.

Hustedia mormoni

Marginifera longispina

Meekella striatocostata

Orthotetes crassus

Productus cora

Productus (Pustula) nebrascensis

Productus pertenuis

Productus punctatus

Productus semireticulatus

Pugnax uta

Rhipidomella pecosi

Spirifer cameratus

Spiriferina kentuckiensis

Allorisma terminale

Allorisma granosum

A viculopinna peracuta

Aviculopecten occidentalis

Aviculopecten whitei

Edmondia nebrascensis

Myalina perattenuata

- Myalina recurvirostris

Myalina subquadrata

Myalina swallovi

Nucula ventricosa

Leda bellistriata

Bellerophon percarinatus

Bucanopsis montfortiana

Euomphalus catilloides

Euphemus carbonarius

Phanerotrema grayvillensis

Soleniscus paludinæformis

Worthenia tabulata

Orthoceras rushense

Tainoceras occidentale

Griffithides seitula
Agassizodus variabilis

Peripristis semicircularis

Conostychus broadheadi

Conostychus ornatus

Carpolithes gramularis

Severy shale.23

Lophophyllum profundum

Fenestella

Rhombopora lepidodendroides

Septopora biserialis

Scaphiocrinus?

Zeacrinus

Archaeocidaris aculeata

Ambocoelia planoconvexa

Chonetes granulifer

Composita subtilita

Dielasma bovidens

Enteletes hemiplicata

Orthotetes crassus

Marginifera longispina

Productus (Pustula) nebrasseensis

Productus pertenuis

Productus cora

Productus punctatus

Spirifer cameratus

Spiriferina kentuckiensis

Allorisma subcuneata

Allorisma granosum

Aviculopectèn

Edmondia nebrascensis

Modiola subelliptica?

Myalina subquadrata

Nueula

Pinna

Schizodus?

Bellerophon carbonarius

Bellerophon percarinatus.

Euomphalus catilloịdes

Euomphalus rugosus

Euphemus carbonarius

Murchisonia

Phanerotrema grayvillensis

Cythere

Alethopteris grandini

Annularia sphenophylloides

Asterophyllites equisetiformis

Calamites suckowii

Neuropteris ovata

Neuropteris scheuchzeri

Pecapteris cyathea

Topeka limestona-Calhoun shale-

Deer Creek limestone.24

Fusulina cylindrica

Lophophyllum profundum

23George L. Smith, The Carboniferous Section of Southwestern Iowa: Iowa Geol. Surver, Vol. XIX, pp. 622 and 633 ; Contributions to the Geology of Southwestern Iowa: Proc. Iowa Acad. Sci., Vol. XXII, p. 282. S. A. Cdden, Geology of Mills and Fremont Counties: Iowa Geol. Survey, Vol. XrII, pp. 144-145 (Section $\mathrm{X}$, numbers 9-13).

24 George $\mathrm{L}$. Smith, Contributions to the Geology of Southwestern Iowa: Proc. Iowa Acad. Sci., Vol. XXIII, p. 88; and Carboniferous Section of Southwestern Iowa: Yowa Geol. Survey, Vol. XIX, p. 637

From conference in the field it was learned that Doctor Smith had made his collections from the Deer Creek (Forbes) limestone, Calhoun shale and Topeka (Meadow) limestone. 
Ceriocrinus hemisphericus

Eupachyerinus tuberculatum

Hydreionocrinus mucrospinus

Archaeocidaris agassizi

Archaeocidaris dininni

Archaeocidaris hallana

Archaeocidaris triseriata

Fenestella tenax

Fistulipora nodulifera

Polypora submarginata

Rhombopora lepidodendroides

Septopora biserialis

Ambocoelia planoconvexa

Chonetes granulifer

Chonetes verneuiliana

Composita subtilita

Dielasma bovidens

Enteletes hemiplicata

Hustedia mormoni

Marginifera longispina

Meekella striatocostata

Orthotetes crassus

Productus cora

Productus costatus

Productus (Pustula) nebrascensis

Productus semireticularis

Pugnax uta

Reticularia perplexa

Rhipidomella pecosi

Spirifer cameratus

Spiriferina kentuckiensis

Squamularia perplexa

Allorisma terminale.

Allorisma subeuneata

Chaenomya minnehaha

Myalina swallovi

Macrodon tenuistriatus

Schizodus wheeleri

Bellerophon carbonarius

Bellerophon percarinatus

Euomphalus catilloides

Euphemus carbonarius

Pleurotomaria

Platyceras parvum

Soleniscus intercalaris

Orthoceras knoxense

Calhoun shale.25

Archaeocidaris (spines)

Eupachyerinus verrucosus
Scarpiocrinus (plates)

Fistulipora nodulifera

Polypora submarginata

Chonetes granulifer

Discina convexa

Orthotetes crassus

Productus cora

Productus nebrascensis

Productus punctatus

Productus semireticulatus

Spirifer eameratus

Aviculopecten

Edmondia

Entolium aviculatum

Myalina subquadrata

Myalina recurvirostris

Pinna peracuta.

Pseudomonotis hawni

Bellerophon carbonaria

Euomphalus rugosus

Pleurotomaria

Deer. Creek (Hawleyville) limestone.26

Fusulina cylindrica

Archaeocidaris

Crinoidea (stems and plates)

Fistulipora nodulifera

Rhombopora lepidodendroides

Septopora biserialis?

Ambocoelia planoconvexa

Composita subtilita

Chonetes granulifer

Chonetes verneuilianus

Dielasma bovidens

Hustedia mormoni

Marginifera longispina

Orthotetes crassus

Orthotetes robustus

Productus semireticulatus

Productus cora

Productus costatus

Productus (Pustula) nebrascensis

Productus symmetricus

Rhipidomëlla pecosi

Pugnax uta

Spirifer cameratus

Spiriferina cristata

Aviculopecten 9

Bellerophon carbonarius

Euomphalus rugosus:

chiefly near the mouth of the ravine (Pilot creek) north of Stennett. and that he had not collected from fossiliferous horizons at a considerable distance (about two-thirds of a mile) up the creek, where the Severy shale members (Union and Lonisville limestone) appear in the bed of the creek.

In the Geology of Montgomery County: Iowa Geol. Survey, Vol. IV. Plate XI (opposite page 392), is a picture of the Fate Quarry, near Stennett, in which the top of the Deer Creek limestone appears in the base of the quarry, the Topeka (Meadow) in the center. atd fragments of the Severy (Union) near the top, as shown in the picture. This quarry was located on the west side of the Nishnabotna; Pilot creek is on the east side of the river.

25J. A. Udden, Geology of Mills and Fremont Counties: Iowa Geol. Survey, Vol. XIIT, pp. 138, 139, 141, 142: Section $\nabla$, numbers 11-13, Section VI, numbers 8-9, and Section VIII,

-26.Samuel Calvin, Geology of Page County: Iowa Geol. Survey, Vol. XI, pp. 423. and 425. Also, J. A. Udden, Geologr of Mills and Fremont Counties. Trey, rol. XI, pp. 423. and 425. 139-146. The following are considered Deer Creek: Section V numbers 3.10; Section, pp. numbers $1-7$; Section IX, numbers $5-8$ 
Strapatollus catilloides Phillipsia

Tecumseh shale.

No fossils are reported.

Lecompton limestone (Cedar Creek and Cullom limestones).27

Cedar Creek limestone

Fusulina cylindrica

Campophyllum torquium

Lophophyllum profundum

Archaeocidaris

Erisocrinus typus

Rhombopora lepidodendroides

Fistulipora nodulifera

Ambocoelia planoconvexa

Composita subtilita

Chonetes granulifer
Chonetes geinitzianus

Marginifera longispina

Orthotetes crassus

Productus cora

Productus costatus

Productus (Pustula) nebrascensis

Productus pertenuis

Spirifer cameratus

Aviculopecten

Pinna peracuta

Bellerophon carbonaria

Peripristis semicircularis

Cullom limestome

Fusulina cylindrica

Kanwaka shale.

There is no distinct list of fossils. 28

THE DOUGLAS STAGE.20

Oread limestone.

Fusulina cylindrica (very many, and large)

Lophophyllum profundum

Chonetes granulifer

Productus cora

Spirifer cameratus

Lawrence shale.

Lophophyllum profundum

Crinoid stems

Chonetes granulifer

Productus (Pustula) nebrascensis

Productus cora

Spirifer cameratus

Iatan limestone.

Crinoid stems

Chonetes granulifer

Productus cora

Productus (Pustula) nebrascensis

Weston shale.

Productus nebrascensis

There are few fossils.

\section{LANSTNG STAGE.29}

Stanton limestone.

Crinoid stems

Productus (Pustula) nebrascensis

Productus cora

Spirifer cameratus

Alga-like markings

Vilas shale.

No fossils are reported.

Plattsburg limestone.

Fusulina eylindrica

Echinoid spines

Lophophyllum profundum

Composita subtilita

Chonetes granulifer

Orthotetes crassus

Productus (Pustula) nebrascensis

Lane shale.

Crinoid stems

27J. A. Udden, Geology of Pottawattamie County: Iowa Geol. Survey, Vol. XI, pp. 221-224. The exposures are small and distant from each other and from other outcrops. The following are considered Cedar Creek. numbers 4 and 5 of Thomkin's quarry section, numbers 4-6 of Martin's quarry section, numbers 1-3 of Bryant's quarry section, number 1 at river bed 4-6 gi Martin's quarry section, numbers 1-3 of Bryant's quarry section, number 1 at river bed
south of Carson, and numbers $4-6$ of Snapp's quarry section. The following are considered Callom: number 1 of Thomkin's quarry section, and numbers 1.3 of Martin's quarry section. Geology of Mills and Fremont Connties: Iowa Geol. Survey, Vol. XIII, p. 138, (Section IV, number 2).

28George L. Smith lists seven fossils from the Platte shales, bat these shales seem to in clade the Lecompton (Cullom and Cedar Creek) limestone. "Contributions to the Geology of Southwestern 'Iowa," Proc. Iowa Acad. Sci., Vol. XXIII, p. 88.

29 Exhanstive lists of fossils from the Douglas and Lansing stages in Iowa have not

heen prepared. Such lists for Missouri may be found in the following reference: Hinds and Greene, Stratigraphy of the Pennsylvanian Series in Missouri: Missouri Bur. Mines, Bull. XIII, pp. $286-288$ and $292-295$. 


\section{KANSAS CITY STAGE.80}

Iola limestone.

Lophophyllum proliferum

Crinoids (stems)

Bryozoa

Chonetes verneuilianus

Orthotetes crassus

Productus

Chanute shale.

Bryozoa

Chonetes verneuilianus

Composita subtilita

Productus cora

Westerville limestone (DeKalb).

Lophophyllum proliferum

Crinoids (stems)

Fenestella

Aulopora

Chonetes verneuilianus

Composita subtilita

Productus cora

Productus costatus

Spirifer cameratus

Straparollus subquadratus

De Kalb limestonie.

Lophophyllum proliferam

Crinoids (stems)

Echinoid spines

Bryozoa

Composita subtilita

Dielasma bovidens

Marginifera longispina

Orthotetes crassus

Productus costatus

Productus semireticulatus

Spirifer camera'tus

Spiriferina kentuckiensis

Cherryvale shale.

Rhombopora lepidodendroides

Eupachycrinus verrucosus

Chonetes verneuilianus

Composita subtillita

Marginifera longispina

Orthotetes crassus

Productus cora

Products (Pustula) nebrascensis

Spirifer cameratus

Spirifer planoconvexus

Aviculopecten occidentalis

Myalina kansasensis

Myalina subquadrata

Myalina swallori

Winterset limestone.

Chonetes verneuilianus

Composita subtilita

Meekella striatocostata

Hustedia mormoni

Productus cora

Productus costatus

Spirifer cameratus

Galesburg shale.

Fusulina cylindrica

Chonetes verneuiliantis

Composita subtilita

Bethany Falls (Earlham) limêstone.

Fusulina cylindrica

Iophophyllum proliferum

Archaeocidaris (plates)

Zeacrinus (plates)

Crinoidea (stems)

Bryozoa

Composita subtilita

Chonetes vermeuilianus

Hustedia mormoni

Marginifera longispina

Meekella striatocostata

Productus cora

Productus costatus

Productus punctatus

Spirifer cameratus

Spiriferina kentuckiensis

Allorisma subcuneata.

Phillipsia

Ladore shale.

No fossils are reported.

Hertha limestone.

Composita subtilita

Spirifer cameratus

Spiriferina kentuckiensis

\section{The Cross Section Along Missouri River.}

The cross section along Missouri river begins at Hamburg, Fremont county, in the southwest corner of the state, and proceeds northward to Crescent, seven miles north of Council

30These lists are from reports in the Iowa Geological Survey on the different members of the Kansas City stage, and from fiold notes by the writer: Madison county (Vol. VII), Decatur county (Vol. VIII) and Clarke county (Vol. XXVII). The lists given for Guthrie county are not included, as the strata there belong to the Des Moines series. See John I, Tilton, "The Strata near Stuart. Towa": Bulletin of the Geological Society of America, Vol. XXXIII p. 153,1922 . Elsewhere there is uncertainty as to the real source of the fossils referred to the Hertha. Only those are permitted in the above list that are also found in Hinds and Greene's report on The Stratigraphy of the Pennsylvanian Series in Missouri, table opposite page 282. 
Bluffs, which is the location of the last known outcrop of Missouri series strata.

The section at the high school ${ }^{31}$ at Hamburg, is as follows:

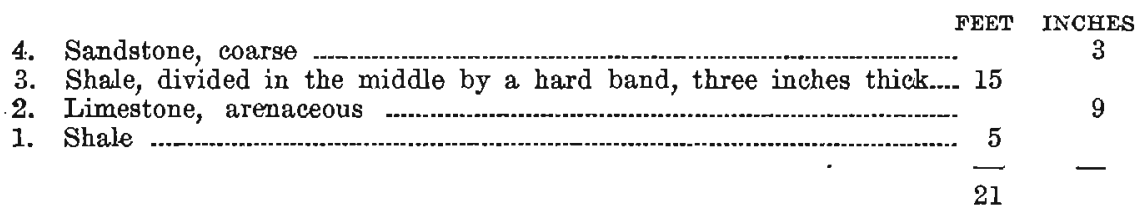

The limestone is 929 feet above sea level, or 16 feet above the Chicago, Burlington and Quincy railroad track at the station, and 29 feet above Nishnabotna river. The outcrop is closely related to the series found two miles northeast at McKissick grove, and to the face of the clay pit at the brick yard south of Nebraska City, ${ }^{32}$ at a distance of about ten miles to the northwest, which is the location of an outcrop and well record used in the cross section from Hamburg to Leon.

Northward along the bluffs bordering the east side of the valley of Missouri river all is concealed by river deposits, drift and loess, which fill a preglacial valley eroded in Missouri series strata, for a distance of thirteen miles to a point three miles south of Thurman. Here in the northwest quarter of the northwest quarter of section 12 appears a three-foot bed of limestone that has the same peculiar characteristics and relation to strata above and below as has the limestone member, No. 2, at the high school at Hamburg, and that, No. 17, in the strata at McKissick grove. The section here found is as follows, as described by Udden, ${ }^{33}$ with modifications:

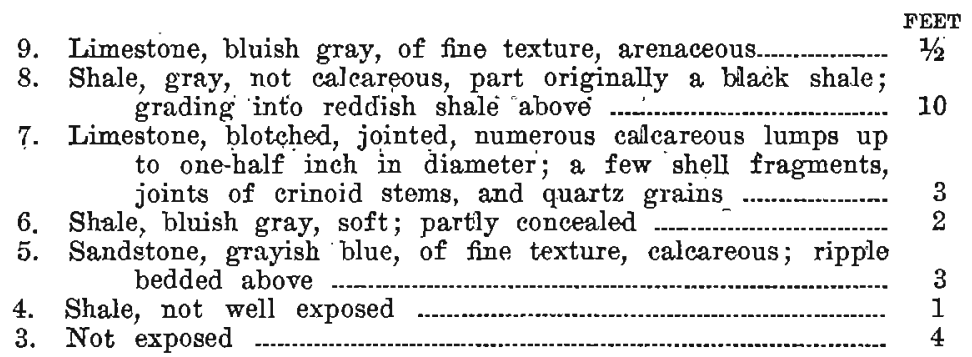

81G. L. Smith, Carboniferous Section of Southwestern Iowa: Iowa Geol. Survey, Vol, XIX, p. 641 .

32For statement of depth of buried channel near Nebraska City, see J. E. Todd, Bull. 158 U. S. Greol. Survey, p. 148. 150.

33J. A. Udden, Geology of Mills and Fremont Counties: Iowa Geol. Survey, Vol. XIII, p. 
2. Limestone

1. Shale, gray

The uppermost limestone, No. 9, and the limestone, No. 7, a few feet below it outcrop along the hillside from this point to the mouth of Plum creek at Thurman. They also appear in the hillsides along the lower course of Plum creek and north of Thurman for about a mile along Missouri valley, just beyond which point there is a sudden and complete change in strata. This is at a point where Todd ${ }^{34}$ recognized the presence of a fault, and where later Smith $^{35}$ found further evidence of it. This fault was later called by Tilton ${ }^{38}$ the ThurmanWilson fault and was traced by him across Montgomery, Cass and Adair counties, and into Dallas county. It was found to have but little difference in the amount of displacement.

Near the center of the north line of section 35, Scott township, Udden ${ }^{37}$ obtained the following composite section, in which the fourth member from the bottom, a hard blue jointed limestone with small granules, is the stratum especially noted as No. 7, three miles south of Thurman, and also as No. 2, at the high school at Hamburg, and No. 17 at McKissick grove:

9. Limestone,' weathered brown; many joints of crinoid stems

8. Shale, chocolate colored, arenaceous, calcareous and micaceous; small gray calcareous nodules.

7. Shale, yellow, calcareous; with nodules

FEET INCHES

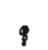

6. Shale, gray, calcareous, very fossiliferous: Iophophyllum proliferum (?), Fistulipora nodulifera (flattened), Rhombopora lepidodendroides, Septopora biseralis, Polypora submarginata (?), Fenestella (?), Chonetes granulifer, Ch. verneuitianus, Spirifer cameratus, Spiriferina kentuokiensis, Prugnax uta, Syntrielasma hemiplicata, Ambocelia planoconvexa, Productus semireticulatus, Murchisonia (?), Nucula(?), denticles of brown color

5. Limestone, gray, organic fragments in almost structureless matrix

34:T. E. Todd, On the Folding of the Carboniferous Strata in Southwestern Iowa: Proc. Iowa Acad. Sci., Vol. I, Part 1 p. 61,1889 ; also, Some Variant Conclusions in Iowa Geology: Iowa Acad. Sci, Vol. I, Part 1

35G. L. Smith, Carboniferous Section of Southwestern Iowa: Iowa Geol. Survey, Vol. $\mathrm{XIX}$, p. 612,1909 .

36John L. Tilton, The Thurman-Wilson Fault through Soutbwestern Iowa, and its Bearing: The Journal of Geology, Vol. XXVII, 1919; Geology of Cass County and Geology of Adair County: Iowa Geol. Suryey, Vol. XXVII; The Strata near Stuart; Iova: Bull. Geol. Soc. America, Vol. XXXIII, p. 153, 1922. See also footnote 1a, page 228, this rolume.

s7Geology of Mills and Fremont Counties: Iowa Geol Survey, Vol. XIII, pp. 148, 149. 
4. Limestone, blue, dense, jointed, with indistinct small granules; many crinoid stems and a few $F u$

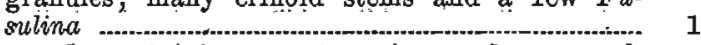

3. Shale, red, containing quartz, mica, and gray cal-

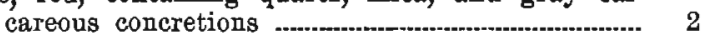

2. Shale, grayish blue, arenaceous, with some mica...-.. 6

1. Shale, red

$$
\frac{6}{19} \quad \frac{6}{7}
$$

As quarrying has not been carried on for many years the above described section is not at present easily obtainable, but with the aid of Mr. Martens, the owner, the sites of former quarries were traced along the hillside. The character of the fragments of limestone was noted as was also the presence of a bed of reddish shale about eight feet thick which lies above the beds of limestone formerly quarried. These conditions were noted northward to the northwest quarter of the southeast quarter of section 26 and to the northwest quarter of the northeast quarter of section 25, beyond which no evidence whatever of the presence of these strata was found.

To the north of the above described exposure and just south of where a road turns west past Wabonsie lake, the thick Topelka (Meadow) limestone appears high in the bluff, below which appears the Deer Creek (Forbes) with its dark chert and shale.

Between the two locations above described.lies the fault, the location of which is thus correctly determined within a distance of three hundred feet. Here the strata change suddenly from the limestone in the McKissisk Grove shale and above the Nyman coal on the south (downthrow) side of the fault, to the Deer Creek limestone and shale north of the fault (upthrow side), a displacement of about three hundred feet as computed by Smith. ${ }^{\mathbf{8}}$

North of the region above described the Deer Creek beds appear along the road in section 14 of the same township, and farther north to the center of section 10 of Lyons township, Mills county (Township 71 north, Range 43 west, opposite Havnies station), a distance of eight miles, there is an almost continuous series of exposures. The following section may be found between sections 25 and 26 of Lyons township. (Township

88lowa Geol. Surrey, Vol. XIX, pp. 647-6i48. 
71 north, Range 43 west), at the quarry near a large stone house.

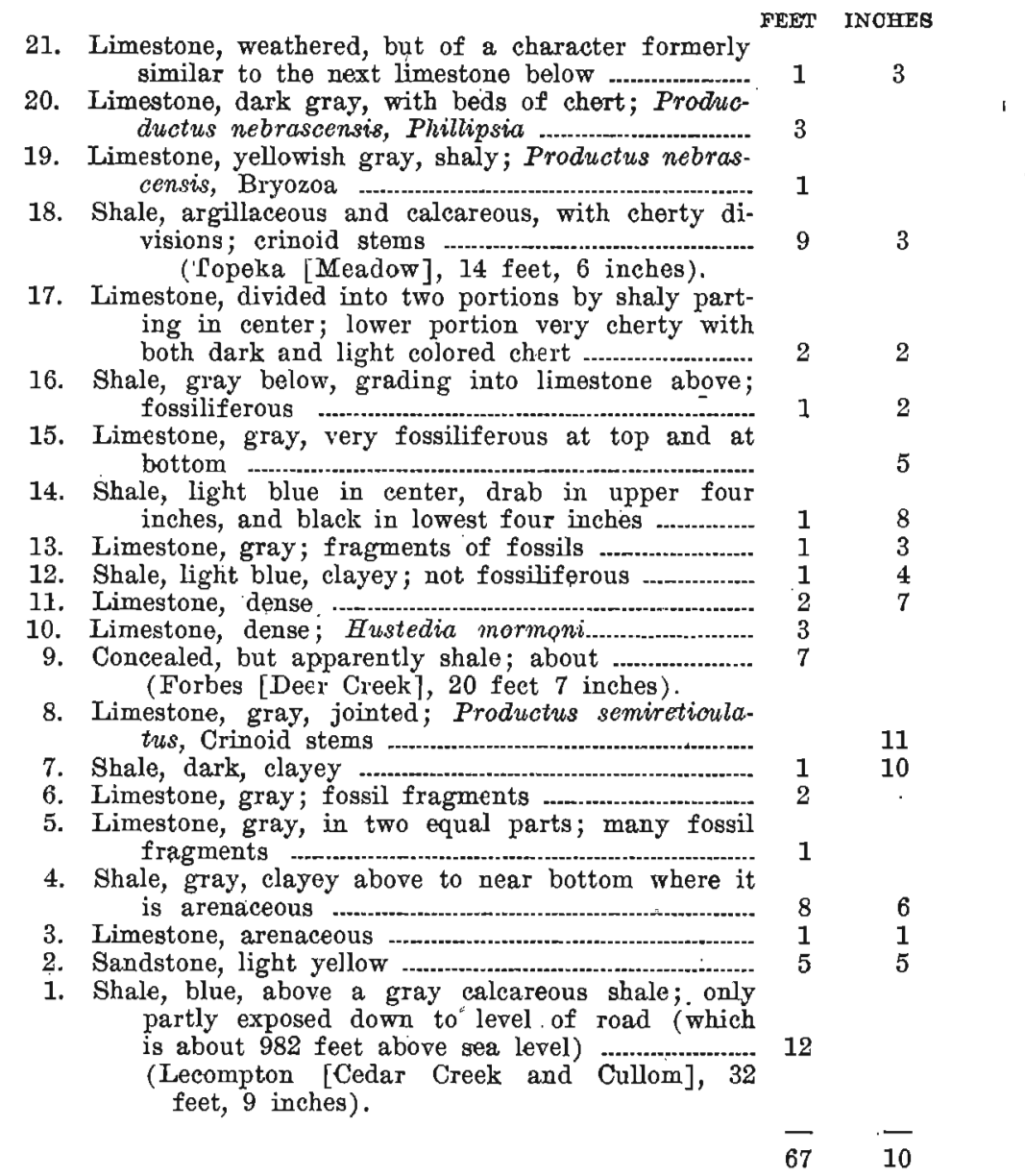

The level of the road at the old stone house is 982 feet above sea level and 37 feet above the Chicago, Burlington and Quincy railroad crossing west. The strata in the interval from the level of the road to the level of the river are not exposed, but it is evident that the Oread (Plattsmouth) limestone belongs in this interval.

For a distance of four miles straight away, or of six miles by the road along the bluff, to where the road crosses Keg Creek near Mills station, no stratified rock appears. At the location mentioned, the northeast quarter of the northeast 
quarter of section 27, Glenwood township, ${ }^{39}$ there is an outcrop of a portion of the Oread (Plattsmouth) limestone by the side of the creek, as follows:

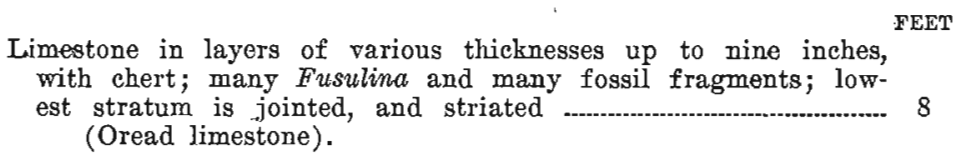

The bed of the creek is here at a level of 938 feet above sea level, and 18.75 feet below the railroad at Pacific Junction.

At Glenwood there is a deep well, a condenserl record of which is as follows ${ }^{40}$ :

\begin{tabular}{|c|c|c|}
\hline \multirow{3}{*}{$\begin{array}{l}\text { Quaternary and recent deposits ( } 175 \text { feet thick, top of } \\
\text { well } 1,132 \text { feet above sea level) }\end{array}$} & HICKNESS & $\begin{array}{l}\text { DEPTH } \\
\text { FEET }\end{array}$ \\
\hline & & \\
\hline & $175^{*}$ & 175 \\
\hline $\begin{array}{l}\text { Missouri and Des Moines series of Pennsylvanian } \\
\text { (thickness, } 1,060 \text { feet) }\end{array}$ & & \\
\hline Limestone, soft, light and darker gray, cherty.......... & 2 & 177 \\
\hline Limestone, dark blue, argillaceous, pyritiferous...-..- & 10 & 187 \\
\hline Shale, black, carbonaceous & $11 / 2$ & $1881 / 2$ \\
\hline Clay, blue, shaly & $61 / 2$ & 195 \\
\hline 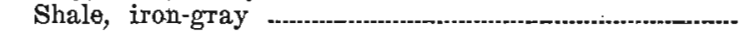 & 8 & 203 \\
\hline Limestone, gray; earthy luster & 24 & 227 \\
\hline $\begin{array}{l}\text { Shale, dark blue gray, fissile; dises of crinoid } \\
\text { stems and fragments of Productus }\end{array}$ & 5 & 232 \\
\hline $\begin{array}{l}\text { Limestone, gray, luster earthy, compact, moderately } \\
\text { hard; with crinoid stems, echinoid spines, and } \\
\text { fragments of brachiopods }\end{array}$ & 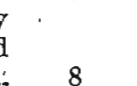 & 240 \\
\hline 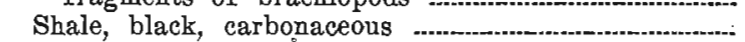 & 4 & 244 \\
\hline Limestone, soft, yellow-gray; with Fusulina & 13 & 257 \\
\hline 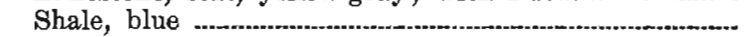 & 7 & 264 \\
\hline Limestone, light yellow, fossiliferous & 9 & 273 \\
\hline Shale, dark red & 16 & 289 \\
\hline $\begin{array}{l}\text { Limestone, brecciated; sample consists of two large } \\
\text { unfractured masses of very hard limestone brec- } \\
\text { cia; limestone gray or reddish; matrix greenish }\end{array}$ & & \\
\hline 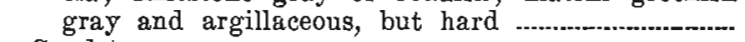 & 25 & 314 \\
\hline Sandstone & 9 & 323 \\
\hline Limestone, argillaceous, bluish gray & 17 & 340 \\
\hline Shale, blue & 2 & 342 \\
\hline 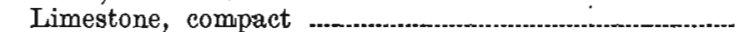 & 5 & 347 \\
\hline Shale; greenish gray, arenaceous, calcareous ............ & 3 & 350 \\
\hline Limestone, hard, gray, highly cherty at 358 feet & 13 & 363 \\
\hline Shale, hard, greenish gray, highly calcareous.......... & 10 & 373 \\
\hline Limestone, light greenish gray, highly argillaceous.. & 5 & 378 \\
\hline Limestone, light yellow, compact, fine grained........ & 18 & 396 \\
\hline Shale, black, carbonaceous; and greenish gray, hard & 9 & 405 \\
\hline 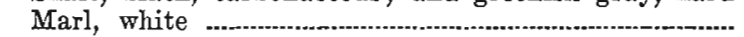 & 2 & 407 \\
\hline Limestone, hard, gray & 8 & 415 \\
\hline Shale, gray; with limestone, argillaceous ................ & 4 & 419 \\
\hline & 19 & 438 \\
\hline
\end{tabular}

39Township 72 North, Range 43 West.

soCondensed from W. H. Norton, Underground Water Resources of Iowa: Iowa Geol. Survey, Vol. XXI, pp. 1139-1140, : 
Limestone, gray, close textured 18

FEET INOHES

Limestone, hard, blue, highly argillaceous; crinoid stems and fragments of brachiopods .................... Shale, black, carbonaceous; impure gray limestone..

Sandstone

Limestone, white and light gray, close textured, earthy luster

Shale, black

Limestone, yellow-gray, fossiliferous, crystalline to earthy

Shale, dark and greenish gray, with Chonetes...........

Limestone, light yellow-gray, soft, fossiliferous........

Shale, green, calcareous

Limestone, white, soft, crystalline to earthy............-.-

Shale, gray, highly calcareous, fossiliferous ...............

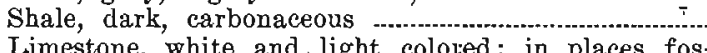

siliferous, with one foot of coal (1) at 612 feet,

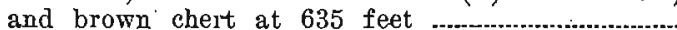

Shale, varicolored, arenaceous, with minute angular fragments of limpid quartz

Sandstone, greenish gray, close and fine graimed, ar gillaceous and calcareous; some siliceous limestone, hard, subconchoidal fracture; with much shale at 706 and 711 feet; vein of salt water at 716 feet

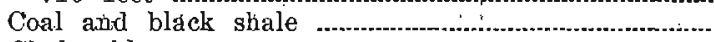

Shale, blue ......... hard; fracture subconchoidal, close textured, fossiliferous and flinty at 732 feet; 4 feet of blue shale at 730 feet

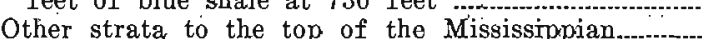

Mississippian:

Strata to bottom of well

456

467

470

476

491

496

508

519

529

550

570

580

595

$43^{\circ} \quad 638$

$47 \quad 685$

Six miles north of Keg creek along the bluff road there is an exposure of stratified rock which is about half a mile south of Henton station. There is a second outcrop just above Henton station. The section described by. Udden ${ }^{41}$ is located in the northwest quarter. of the northwest quarter of section 29 (Township 73. North, Range XLIII west). It is as follows:

4. Shale, gray with thin calcareous layers and occasional calcareous concretions from one to two inches in diameter; denticles of annelids, minute conical teeth, and a small Productus

FEET

Limestone, yellow or gray

2. Limestone, gray or cream. colored, cherty, minute oölitic grains and fragments of shells, a few small grains of iron pyrites

1. Limestone, light bluish gray, in heavy - ledges with some shaly layers and with irregular nodules of chert and minute oölitic grains. Between the lower courses are dark carbonaceous seams containing brachiopods, sponge spicules, spinese of crinoids and of Arohaeocidaris and

41J. A. Udden, Geology of Mills and Fremont Counties: Iowa Geol. Survey, Vol. XIII, pp. $135-136$. 
Fucoid-like impressions; Erisoorinus typus, Eupachycri-
nus verrucosus, Fistulipora nodulifera, Bhombopora le-
pidodendroides, Ambocelia planoconvexa, Chonetes gran-
ulifer, Orthotetes orassus, Productus cora, P. costa-
tus, P. pertemuis, Composita subtilita, Spirifer camera-
tus, Allorisma subcuneata, Chatnomya leavenworthensis,
Ch. minnehaha, Solenomya (?), Pinna peraouta, Belle-
rophon (large) and other gasteropods ...-.

The base of the section is close to the level of the railroad track, which is here 963 feet above sea level.

In the list of fossils the large proportion of pelecypods and crinoids is noteworthy. The writer is classifying the section as a part of the Lansing stage (Stanton limestone). It is clearly below the Oread limestone, suggests the Weeping Water limestone of Nebraska, and may help to fix the Weeping Water in its proper place in the geologic column as recognized in Missouri and Iowa.

White ${ }^{42}$ described an exposure in the valley of Mosquito creek that is not now available, and Udden in his report on the Geology of Pottawattamie county ${ }^{33}$ mentions the outcrop as follows: "On the left bank of Mosquito creek, near the center of the west line of section 21, Township 75 north, Range XLVH west, there are some excavations which were made in quarrying limestone many years ago. The strata are not now well exposed and no quarrying has been done for many years. In White's report the rock is described as consisting of about seven feet of limestone with marly partings. Some of the upper layers are said to have been flinty. From specimens picked up on the site of the quarry it appears that the limestone of this place is of two kinds. One chip consisted of indurated, calcareous, fragmental rock of fine texture in which the fragments are largely composed of some organic structure. These are more or less rounded by trituration, and are sometimes surrounded by a thin accretive erust of structureless calcite, and then resemble incipient oölitic grains. The other type of limestone represented in the fragments likewise had a clastic, compact structure, in which larger fragments of shells and joints of crinoid stems are firmly imbedded in a

42C. A. White, Geology of Iowa, Vol. 1, p. $379,1870$. 1900.

43J. A. Udden, Geology of Pottawattamie County: Iowa Geol. Survey, Vol. XI, p. 226, 
copious matrix composed mostly of very minute calcareous particles."

About six miles still farther northwest. is located the last of the series of Missouri series strata found in Iowa. Udden ${ }^{4}$ describes the condition as follows: "In the southeast quarter of section 27, and in the northeast quarter of section 34, Crescent township, beds of limestone and shale are almost continuously seen at the base of the bluffs of Missouri river for the distance of three-fourths of a mile, rising about twenty feet above the plane of the adjacent bottom land. Some quarrying was done at this place several years ago and the exposures show a succession of beds nearly twenty feet in thickness.

5. Limestore, yellowish and gray, in ledges from six inches to ono foot in thickness, compact near the base, in some parts brecciated and in others having a finely oölitic texture. A polished specimen of this rock is seen to consist of rounded and incrusted calcareous fragments imbedded in a matrix of almost transparent crystalline calcite. The fragments are of different sizes. Some have a diameter of nearly a millimeter, and these are mingled with others of about one-fifth that diameter. Most appear elliptical in section. Some of the large fragments have a nucleus with a structure like a fragment of Striatopora. A few still larger fragments are pieces of small shells. This specimen also exhibits several small, crooked joints or fissure veins filled with pure crystalline calcite. Another specimen appears to the unaided eye as an ordinary compact gray limestone, but as seen under a lens it appears to be fragmental, consisting largely of small Fusulinas, some of which are surrounded by a thin calcareous crust. These, together with finer fragmental material, are imbedded in a structureless calcareous matrix. In some cases the fragments are welded together as if by partial solution and redeposition of this substance. Minute crevices and veins filled with crystalline calcite are abundant everywhere. There are also abundant plain evidences of small faulting and brecciation by fracture......................... 5

4. Shale, yellow

3. Limestone, yellowish gray, with occasional Fusulinas, compact in texture above but locally oölitic below, in some places quite soft. Contains Allorisma subonineata

2. Shale, blue, with numerous fossils and occasional crystals of selenite. The fossils observed were: Fusulina cylindrica (small size), Archaeocidaris triseriata, Eupachyorinus verrucosus, Erisocrinus typus, Fistulipora noduli fera, Rhombopora lepidodendroides, Chonetes granulifer,Melcella striatocostata, Productus cora, $P$. costatus, $P$. nebrascensis, Composita subtilita, Spirifer cameratus (large)

FEET

1. A simple massive ledge of fine-grained oölitic limestone, seen 
to contain pieces of Chenomya, Bakevillia illinoiensis (?), and having on its upper surface partly imbedded, Axophyllum rude, Lophophyllum proliferum, Composita subtilita, Produotus cora, and numorous crinoid stems. In a thin section of the rock in this ledge the oölitic spherules are seen to be imbedded in a transparent matrix of crystalline calcite. They average about onefourth of a millimeter in diameter and barely fall below the limit of ready recognition to the unaided eyc. The microscopic aspect of the rock is that of an ordinary finely granular limestone. Most of the rounded grains are elliptical in section and some of them have a crystalline transparent nucleus. In other cases the nucleus is a minute organic fragment, such as a tiny bit of Fusulina or of the joint of a crinoid stem. These nuclei are surrounded by an opaque crust of structureless calcite about one-fortieth of a millimetex in thickness. Exposed

Udden ${ }^{45}$ further states: "White's. statement" that" the Mosquito creek quarries are in the same ledges as those exposed in the bluff south of Crescent, is corroborated by the observation on the lithological character of the ledges. At both places there is an oölitic limestone of fine texture."

The bottom of the strata above described is 980 feet above sea level.

A projection northward of the sections described from Fremont and Mills counties, but with the lower dip required by the section on Keg creek, the record of the deep well at Glenwood, and the section at Henton, would bring the lowest limestone beds of the Pennsylvanian formations of southeastern Nebraska in line with the strata found at Mosquito creek and near Crescent. The general sequence and character of the strata in the two places seem to correspond. In the present paper they are classed as belonging to the Lansing stage, and probably to the Plattsburg substage.

The next outcrop to the north from Crescent is twenty miles away at Logan, where strata deep down in the Des Moines stage outcrop, the relations of which strata are discussed in the chapter on Areal Distribution.

The Cross Section Along East Nishnabotna River

The cross section along East Nishnabotna river extends from Hamburg, Fremont county, to Lorah, Cass county. It is pos-

45Idem, page 230.

46Geology of Iowa, Vol. I, p. 379, 1870. 


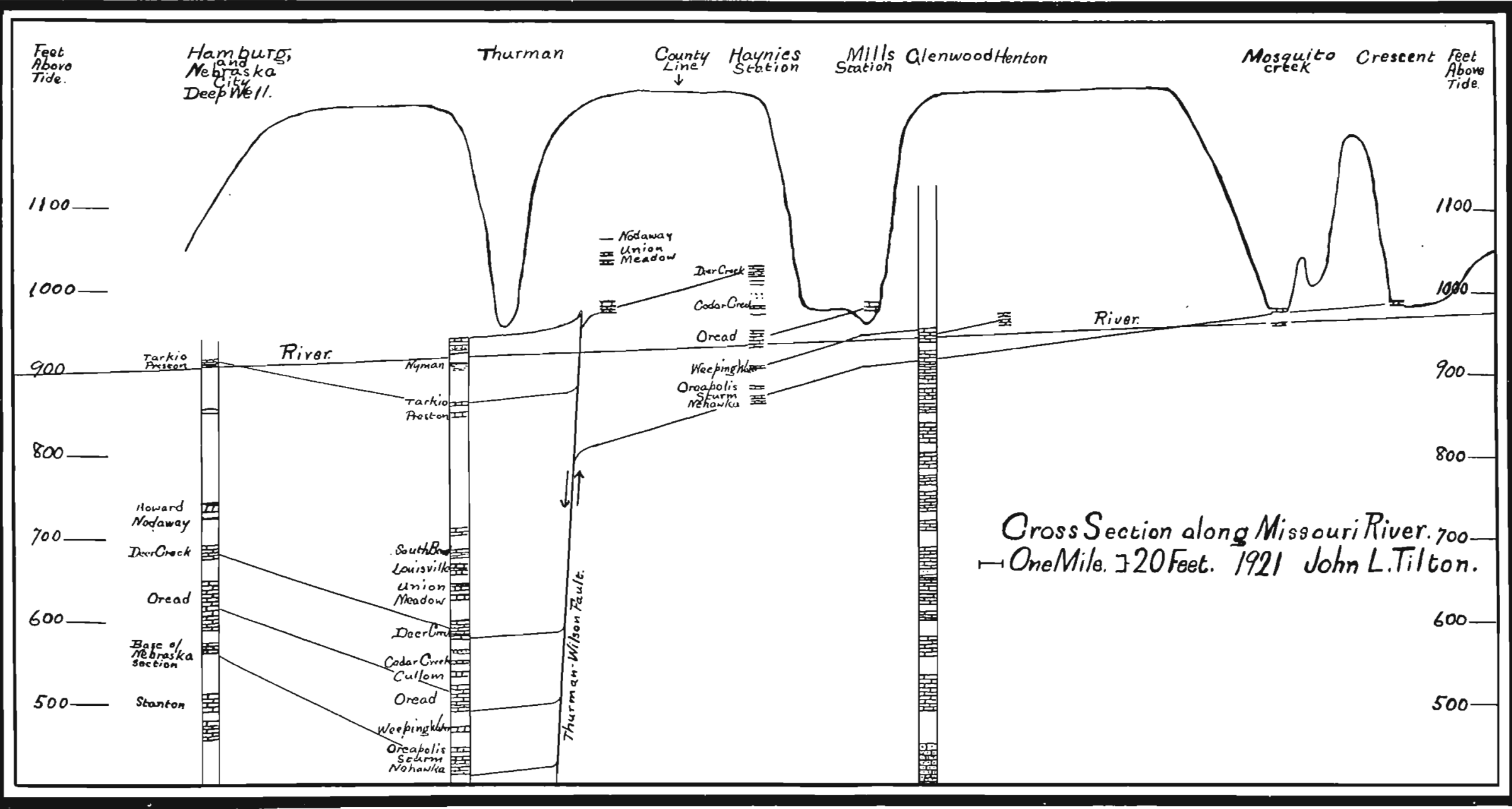

Tho cross section along Missouri river from Mamburg to Crescent. 
sible to obtain the elevation of the river bed above sea level not only at Hamburg and at Lorah, but also at Riverton, Shenandoah, Red Oak, Stennett, Elliott, Griswold, Lewis and Atlantic; and to make use of the descriptions of strata at Hamburg which have been so carefully prepared by Udden and Smith, of those at McKissick grove and Essex prepared by Calvin and Smith, and of those at Stennett, Lewis, Fox quarries, and Turkey creek south of Atlantic prepared by the writer. The record of the outcrop at Hamburg is used also in the cross section northward along Missouri river, and in that eastward to Leon. The various outcrops of strata are referred to the level of water in East Nishnabotna river and drawn in their proper positions above sea level.

Both Udde $n^{47}$ and Smith $^{48}$ give detailed records of strata found at the high school at Hamburg.

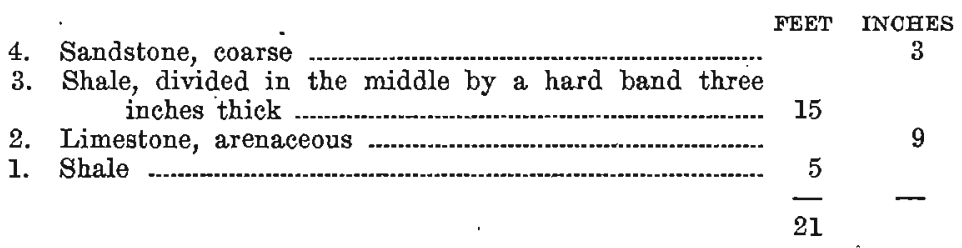

The limestone is 929 feet above sea level, or 16 feet above the Chicago, Burlington and Quincy railroad track at the station, and 29 feet above low water in Nishnabotna river.

These strata Smith refers to the McKissiek Grove shale, and correlates the arenaceous limestone, No. 2, with the third layer from the top (No. 17) at McKissick grove, which stratum is characterized by spheroidal lumps about half an inch in diameter.

The McKissick grove series of outcrops extends east and west through section 13 (Township 67 north, Range 42 west), two miles northeast of Hamburg. This section also is described by both Udden ${ }^{49}$ and Smith. ${ }^{50}$ Smith's description, with slight additional interpretation, is as follows: p. 151 .

47J. A. Udden, Geology of Mills and Fremont Counties: Iowa Geol. Survey, Vol. XIII,

48G. L. Smith, Carboniferons Section in Southwestern Iowa: Iowa Geol. Survey, Vol $X I X$, p. 641 .

49Idem, pp. 15i-154.

50G. I. Smith, Contributions to the Geology of Southwestern Iowa: Proc. Iowa Acad. Sci., Vol. XXIII, p. 80; also Iowa Geol. Survey, Vol. XIX, p. 639. 


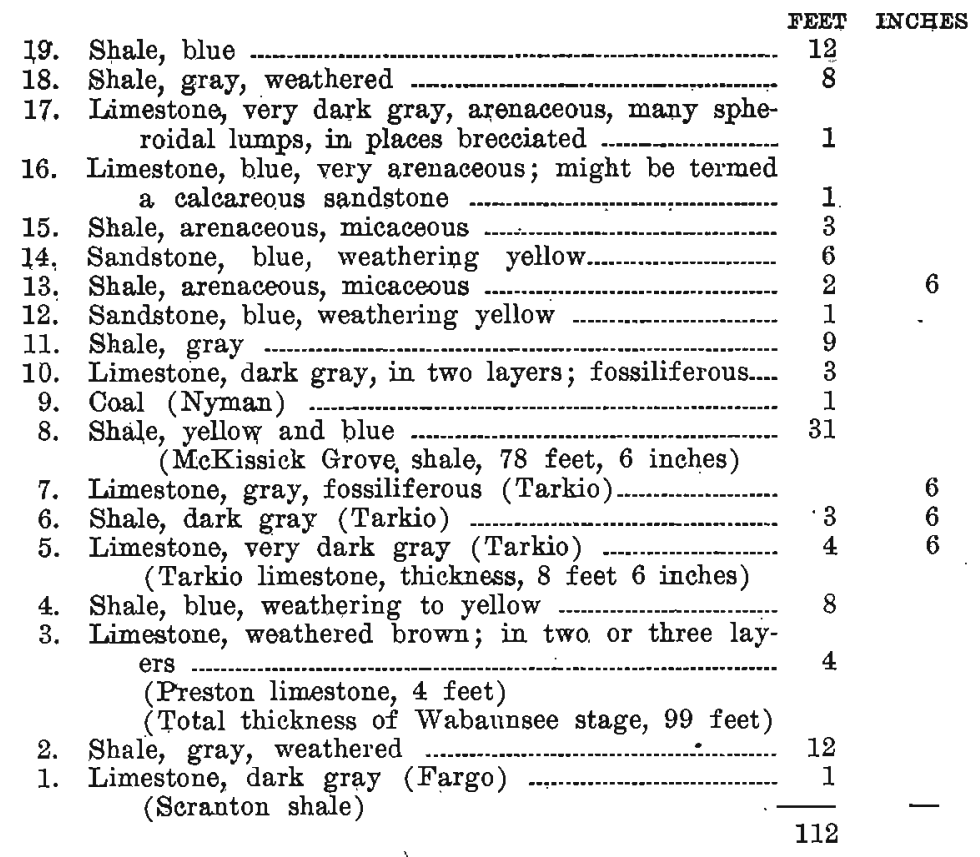

The lowest stratum is close to the level of the railroad track, which is here seventeen feet above the level of the water in Nishñabotna river near by.

The third outcrop to be used is located two miles southeast of Essex, on Rocky Branch, the northwest quarter of the southeast quarter of section 36, Township 70 north, Range XXXIX west. It is described and interpreted by Smith as follows, page 635, Vol. XIX, Iowa Geological Survey:

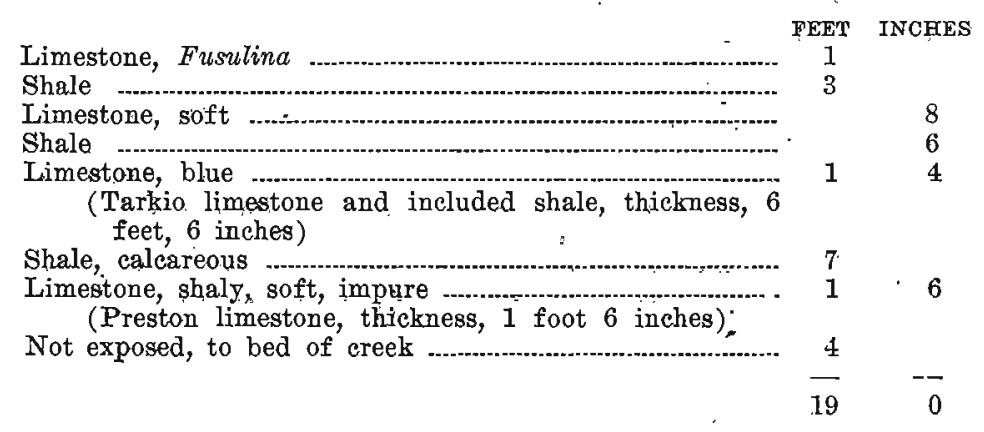

At present but a few scattered fragments of limestone and no exposures of shale are to be seen near either Climax or Co- 
burg, Montgomery county; but Lonsdale ${ }^{51}$ gives the following record, the base of the section apparently being close to the bed of Walnut creek, west of Climax:

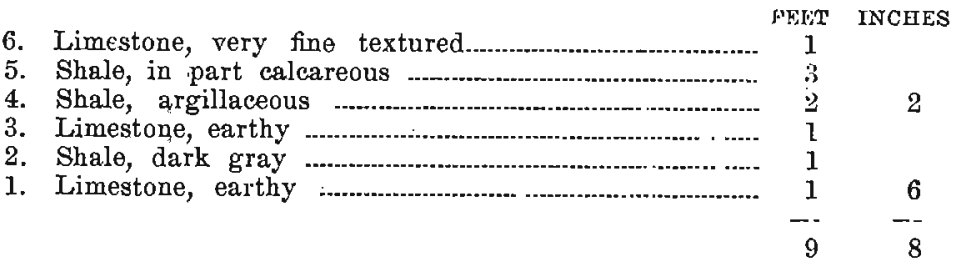

The absence of the blue limestone, the shaly and earthy character of the limestone beds which are present, and the higher position of the Tarkio where it is to be seen near Essex with dip to the southwest, make it probable that this limestone at Climax is Preston limestone. ${ }^{52}$ Strata of the same horizon outcrop three miles south of Stanton.

A mile southwest of Red Oak a slight exposure may be found at the mouth of a small ravine; southwest ruarter of the southwest quarter of section 32, Township 72 north, Range 38 west.

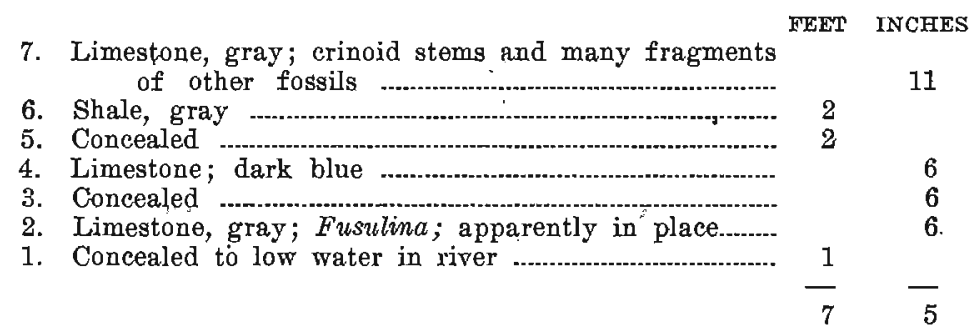

Apparently this imperfect exposure is of the Fargo in the top of the Scranton shale, only the upper portion of which limestone appears in the McKissick grove section. What little may be seen corresponds as well as need le expected with the description of the Fargo as found in eastern Nebraska, and fits into the general sequence.

Lonsdale $^{58}$ gives the following record of a deep prospect hole at Red Oak.

э1E. H. Lonsdalo, Geology of Montgomery County: Iowa Geol. Survey, Vol. IV, p. 395. 52Calvin also gives a detailed description of the Preston limestone and associated shale. Geology of Page County: Iowa Geol. Survey, Vol. XI, p. 432.

$58 \mathrm{E}$. H. Lonsdale, Geology of Montgomery County: Iowa Geol. Survey, Vol. IV, pp. 396-397. 


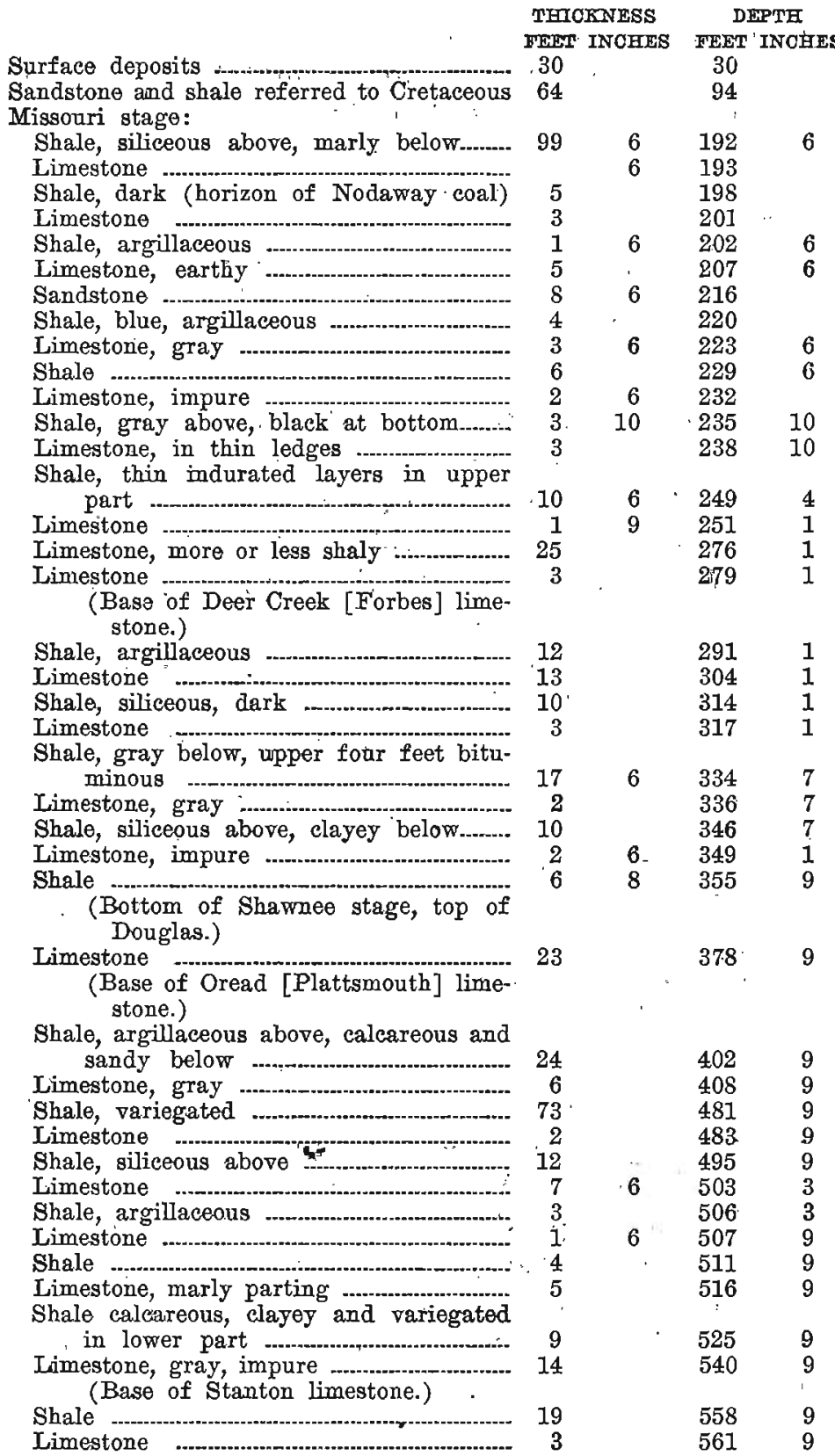

It is judged that the dark shale in this record which is reported at a depth of 198 feet is at the horizon of the Nodaway coal. For this correlation and all the other correlations in 
parentheses in the Missouri series, the writer is responsible. The drilling apparently went to the base of the Lansing stage. It is located south of the fault.

Between the exposure a mile southwest of Red Oak and the one at an old quarry on the west side of Nishnabotna river a little north of west from Red Oak, there is a complete break in the sequence of strata and an abrupt change in dip from the southwest to three degrees and forty-five minutes to the southeast (as measured at Riverview park). The strata at Riverview park, ${ }^{54}$ which are located on the same side of the fault as the old quarries named, and but a mile and a quarter farther to the northeast, are characterized by an abundance of Fusulina cylindrica, some of the beds containing little else, a condition so pronounced that it cannot be duplicated ${ }^{55}$ in any other horizon of the Missouri series in this part of the country. The same strata outcrop on Turkey creek, south of Atlantic in Cass county, in Harrison township in Adair county, and in the bluffs south of Plattsmouth, Nebraska. They are the beds of the Oread limestone. At Riverview park the section found is as follows:

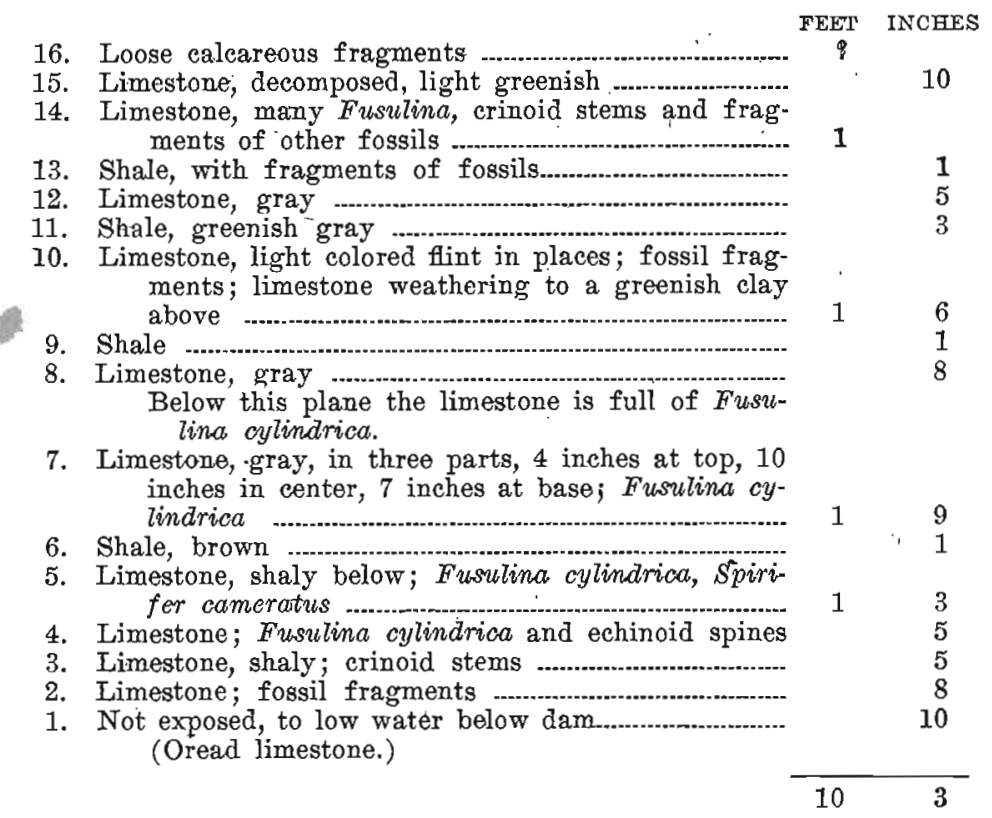
West.

54Northwest quarter of the northeast quarter of Soction 29, Township 72 North, Range 38 55'The nearest approach is in the upper part of the DeKalb limestone as seen in Brushy Branch, Madison county. 
The Thurman-Wilson fault passes between these ledges of the Oread limestone, which lie on the northwest side of the fault, and the outcrop of Fargo (Scranton) limestone a mile down the river from Red Oak, which is on the south side of the fault.

The Lecompton (Cullom) limestone comes up to the river deposits or to the glacial drift somewhere between Riverview park and the outcrop of the Lecompton (Cedar Creek) limestone that is in the road north on the west side of the river (southwest quarter of the southeast quarter of section 5). The Deer Creek (Forbes) and the Topeka (Meadow) are by the roadside farther north..$^{56}$ The next series of sections to be used may be found along a ravine north of Stennett, extending from the southeast quarter of the northeast quarter of section 27, Township 73 north, Range 38 west, eastward a little past the center of section 26 . The record of the strata is as follows:

17. Limestone, very fossiliferous; crinoid stems, echinoid plates, Myalina (three species), Bellerophon, Productus nebrascensis, Bryozod (three

FEET INCHES species)

16. Limestone, decomposing; fossit fragments, crinoid

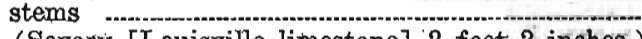
(Severy [Louisville limestone], 2 feet 2 inches.)

15. Shale, calcareous above, gray below

4. Shale, black

13. Limestone; gray; Chonetes, Marginifera longispina, crinoid stems

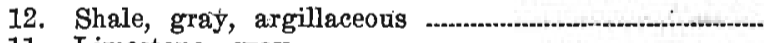

11. Limestone, gray

10. Shale, gray; argillaceous

9. Limestone, gray

8. Shale, drab

(Severy [Union limestone, with shale above it], thickness, 8 feet, 8 inches.)

7. Limestone (forming the bed of the ravine part of the way); Productus nebrascensis all through the bed, crinoid stems near top ........................

6. Shale, argillaceous, dark

5. Limestone (Fopeka limestone [Meadow], and shale above it, thickmess, 4 feet, 5 inches.)

4. Shale, black

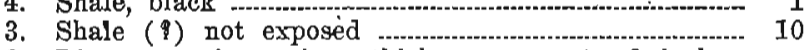

1. -5

9

25

111

15

10

1

2

10

2. Limestone, in various thichnesses up to 6 inches,

56 In Lonsdale's report on the Geologyt of Montgomery County: Iowa Geol. Survey, Vol. IV, may be fonnd Plate IV, giving a view of the old Fate Quarry at Stennett. The limestone at the bottom of the picture is the top of the Deer Creek. The Topeka limestone is that through the center, a bed of shale separating it from the Deer Creek. Along the top of the bluff may be seen the fragments of the Severy (Union limestone), separated from the Topeka limestone by $a$ bed of shale. 
with shaly partings; a Fusulina limestone in center; one stratum bituminous ....................-. 8

(Deer Creek limestone [Forbes] and shale above, thickness, 19 feet, 4 inches.)

1. Not exposed, to river

$$
\frac{8}{42} \quad \frac{6}{1}
$$

Because of the changes in dip related to a low fold paralleling the fault upon the northwest side the Oread is exposed again at Lewis, and the lowest beds with their great abundance of large Fusulina appear in the valley of 'Turkey creek five miles farther to the northeast.

The Spring creek section near Lewis is in the west center of the northwest quarter of section 9, Cass township, Township 75 north, Range 37 west. The part of it which belongs to the Missouri stage is as follows:

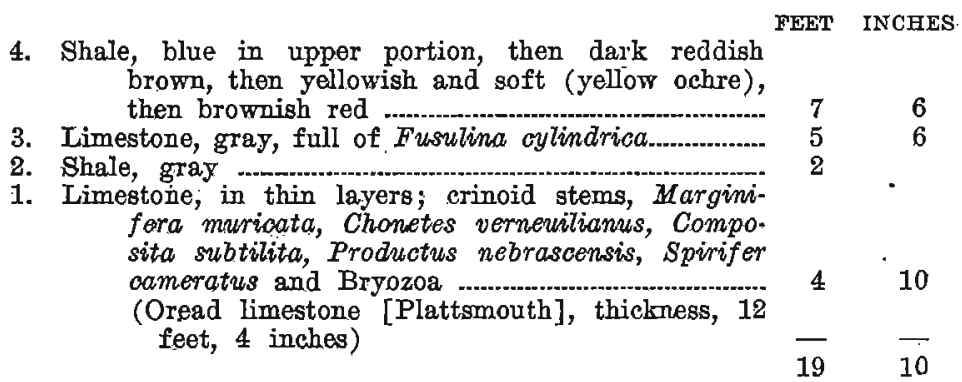

A limestone which is exposed. for a thickness of three feet in the side of a ravine in the south half of section 1, Cass township, is a mass of large Fusulinas. Across the road to the east an exposure of six inches of this limestone which belongs near the top of the bed and is here thin bedded, is crossed by the creek. Here may be seen crinoid stems, Bryozoa, Chonetes, and many fragments not identifiable. All of these beds' belong to the Oread limestone.

The prospect hole drilled at Atlantic is located in the northeast quarter of the southeast quarter of section 5, Grove township (Township 76 north, Range XXXVI west). It is published on pages 1121 to 1122 of volume XXI, Iowa Geological Survey, and is reproduced on pages 257 to 258 of the Geology of Cass County: Vol. XXVII, Iowa Geological Survey. The part that has been referred to the Missouri and Des Moines series is as follows, the remainder being condensed: 


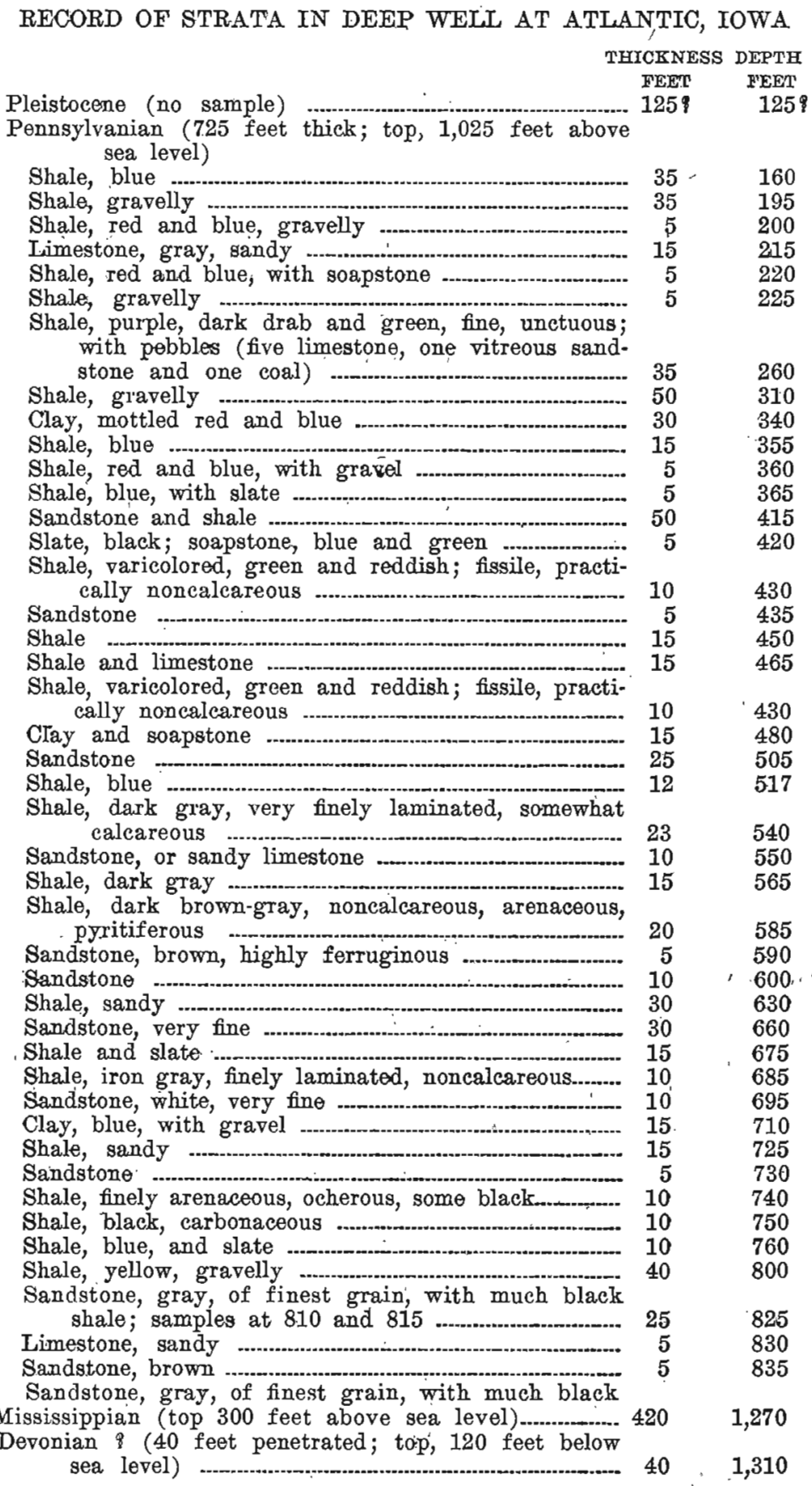

It is not believed that any of the strata penetrated in this 


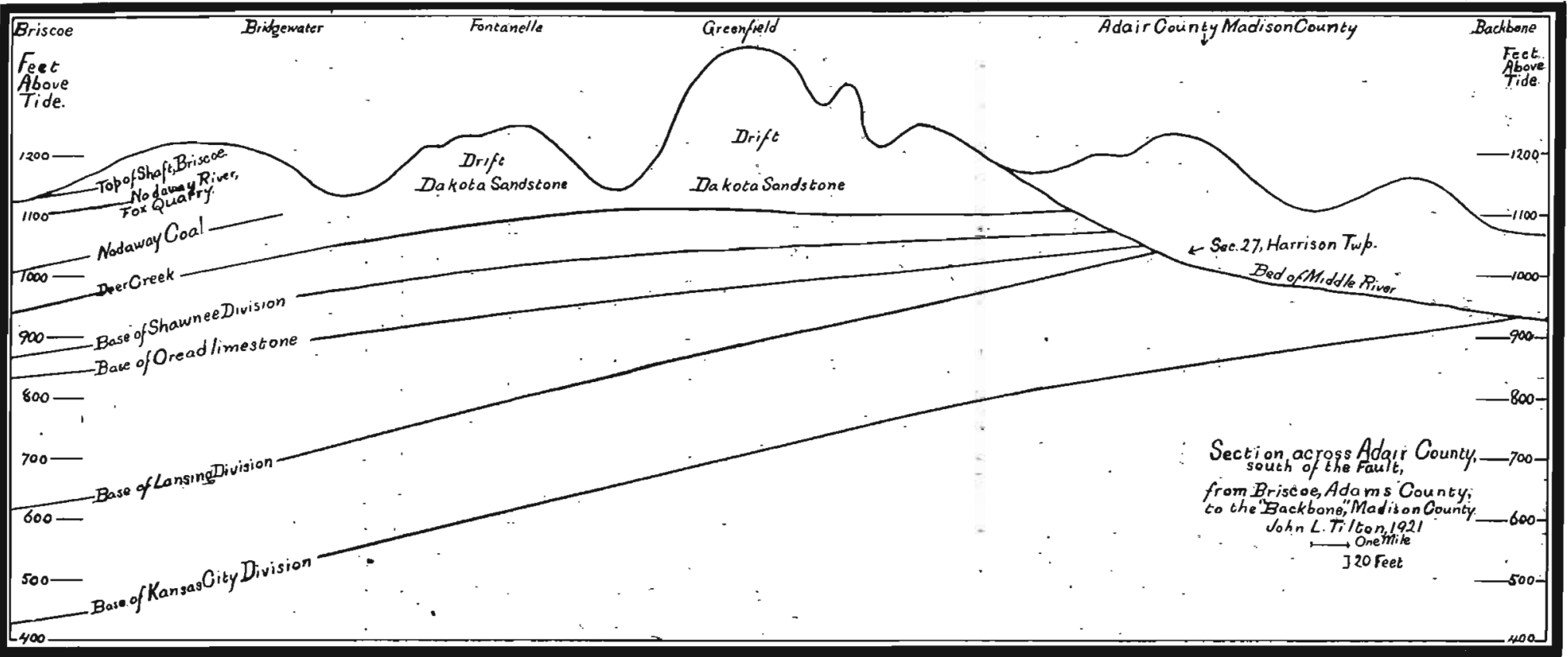

Section across Adair connty, south of the Thurman-Wilsor fault, from Briscoe, Adams county, to the "Backbone," Madison county. 
well belong to the Missouri series. The fifteen feet of limestone at a depth of 215 feet corresponds to the limestone that outcrops north of Stuart, and the coal at about 260 feet corresponds well with the coal that has been mined at Eureka shaft in Adair county and north of Stuart in Guthrie county, in both of which places the limestone ${ }^{57}$ and coal belong deep in the Des Moines stage.

A cross section already published in the Geology of Adair County ${ }^{58}$ connects the strata at Briscoe, Adams county, with the strata outcropping along Middle river in eastern Adair and western Madison counties, along a line south of the ThurmanWilson fault. In the diagram as then published the base of the Deer Creek limestone should have been drawn lower down, so as to outerop in the center of Harrison township, Adair county. The diagram is here reproduced with modifications.

\section{The Cross Section from Nebraska City, Nebraska, to Decatur City and Leon, Iowa.}

The cross section from Nebraska City, Nebraska, to Decatur City and Leon, Iowa, extends east and west along the sixtyeighth tier of townships. This cross section has the advantage of a record of a deep well at Nebraska City, one at Coin, one at College Springs, one at Clarinda, one at Bedford, and one at Leon. The outcrops near the line are few, the strata being concealed by drift excepting at scattered outcrops in some of the river valleys. To the north at some distance are the outcrops at Essex, Coburg, Hawleyville, Brooks, and Westerville; and to the south, outerops at Itamburg, Coin, Braddyville, Davis City, and west of Lineville.

The record of the Nebraska City well may be found on page 1105 of volume XXI of the Iowa Geological Survey, and also on page :651 of volume XIX. While the interpretation offered there does not give the subdivisions of the Missouri series it is believed that with the assistance of the outcrops in the clay pit at Nebraska City and with the aid of the Nebraska section as drawn by Condra and Bengtson the horizons of the

$57 \mathrm{~J}$ ohn L. Tilton, The Strata near Stuart, Iowa: Bull. Geol. Soc. America, Vol ẌXXIII, p. 153,1922 .

58John I Tilton, The Thurman-Wilson Fault through Southwestern Iowa, and its Bearing: Journal of Geology, Vol. XXVII, p. 387; and Geology of Adair County: Iowá Géol. Survey, Vol. XXVII, p. 804 . 


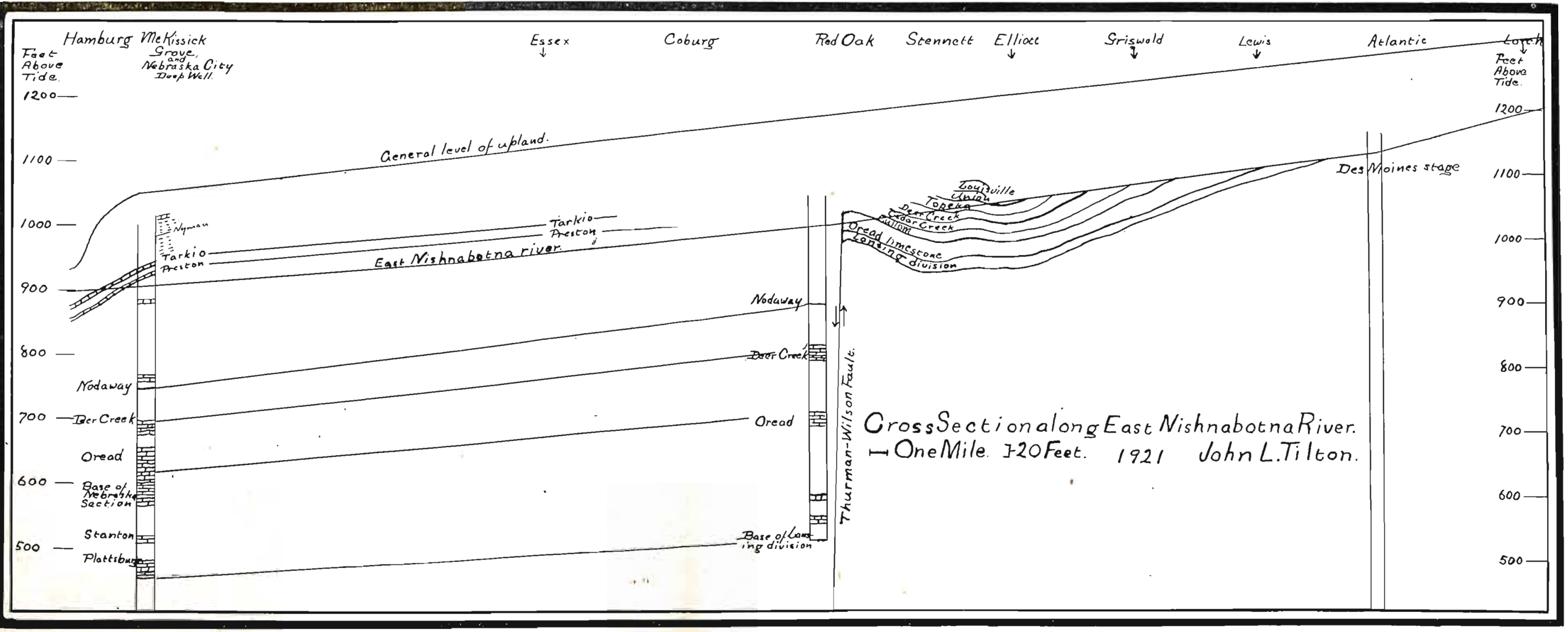


Tarkio, Deer Creek, and Oread limestones and the base of the section of Condra and Bengtson can be made out with considerable certainty; and possibly the base of the Hertha limestone may be determined, though with less of certainty. Between the base of the Condra and Bengtson section of the Pennsylvanian Formations of Southeastern Nebraska and the supposed base of the Hertha is a series of limestones and shales that are provisionally assigned names in accordanice with their apparent relations. It is the judgment of Dr. George L. Smith that the well at Nebraska City is at the level of the Tarkio limestone, and that the shale dug for brick at the brickyard just south of the city is the McKissick Grove shale, the shale above the Tarkio limestone, and with this judgment the writer is in full accord. From this it is estimated that the Deer Creek is the limestone recorded at a depth of 250 feet, the Oread limestone is the one at 325 feet, the base of Condra and Bengtson's section is at 382 feet, and the base of the Hertha limestone (the base of the Missouri series) is at a depth of 702 feet. A condensed record locating the above named horizons is as follows:

\begin{tabular}{|c|c|c|}
\hline \multirow{3}{*}{$\begin{array}{l}\text { Tarkio limestone } \\
\text { Top of well }\end{array}$} & \multicolumn{2}{|r|}{ FEET ABOVE } \\
\hline & DEPTH & $\begin{array}{c}\text { SEA LEVEL } \\
940\end{array}$ \\
\hline & & 930 \\
\hline Todaway coal ...... & 215 & 715 \\
\hline Creek limestone (Forbes) & 250 & 680 \\
\hline d limestone (Plattsmouth). & 325 & 605 \\
\hline of Condra and Bengtson section & 382 & 54 \\
\hline$\theta$ of Hertha limestone & 702 & 228 \\
\hline of Mississippian (Vol. XXI, I. G. S.) & 1,020 & $-90^{\circ}$ \\
\hline 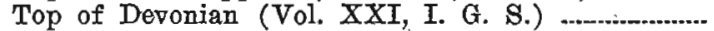 & 1, & $\mathbf{- 5 1 0}$ \\
\hline ian (Vol. XXI, I. G. S.) & & $-1,230$ \\
\hline & & \\
\hline
\end{tabular}

Both Udden ${ }^{68}$ and Smith $^{60}$ give detailed records of strata found at the high school at Hamburg:

4. Sandstone, coarse

FEET INCHES

3. Shale, divided in the middle by a hard band three inches thick.

2. Limestone, arenaceous 15

1. Shale

59J. A. Udden, Geology of Mills and Fremont Counties: Iowa Geol. Survey, Vol. XIII, p. XIX, p. 641 . 
The limestone in this section: is 929' feet above sea level, or 16 feet above the Chicago, Burlington and Quincy railroad track at the station, and 29 feet above low water in Nishnabotna river. These strata Smith refers to the McKissick Grove shale, and he correlates the arenaceous limestone, No. 2, with the third layer from the top (No. 17) at McKissick grove," which stratum is characterized by spheroidal lumps about half an inch in diameter.

The McKissick grove series of outcrops extends east and west through section 13, Township 67 north, Range 42 west, two miles northeast of Hamburg. ' It is described by both Ud$\operatorname{den}^{61}$ and Smith. ${ }^{62}$ Smith's description, with slight additional interpretation, is as follows:

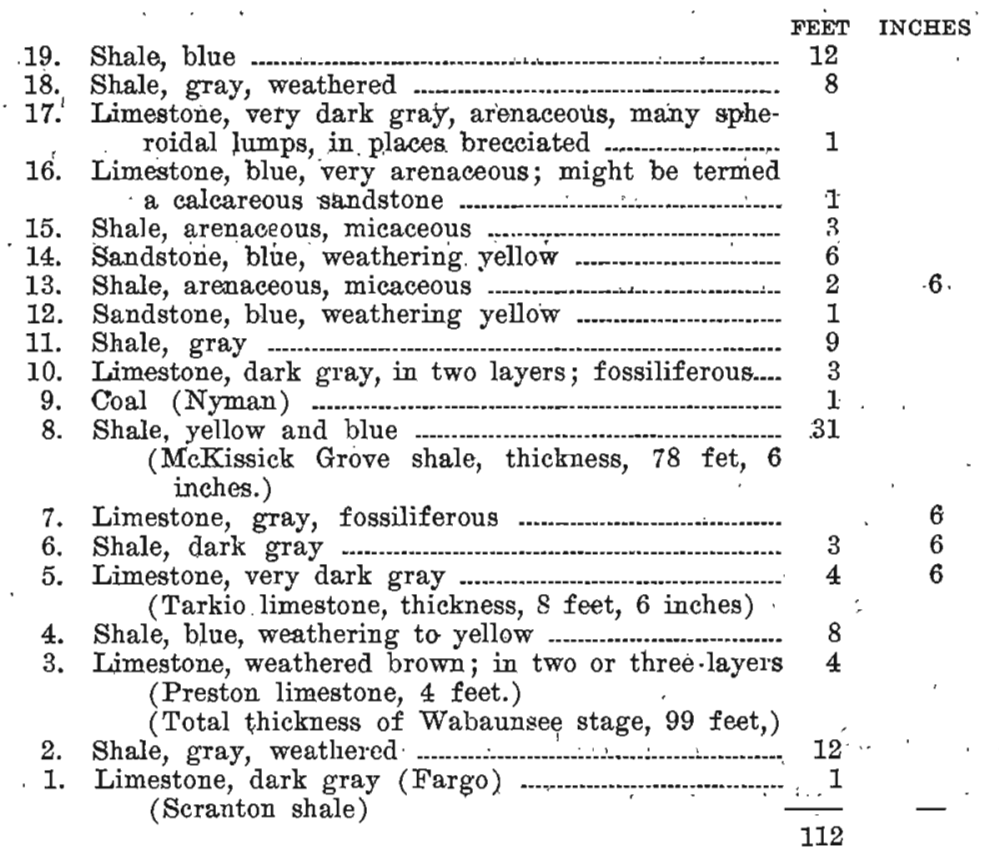

The lowest stratum is close to the level of the railroad track, which is here seventeen feet above the level of the water in Nishnabotna river near by.

A record of the core drilling at Coin may be found in vol. ume XIX of the Iowa Geological Survey, pages 630 to 633 .

61Idem, pp. 151-154.

62G. L. Smith, Contributions to the Geology of Sonthwestern Iowa: Proc. Iowa Acad. Sci., Vol. XXIII, p. 80; also Iowa Geol. Survey, Vol. XIX, p. 689. 
The shale between the Deer Creek (Forbes) and the Oread (Plattsmouth) limestones here seems to be thickening toward the east. A condensed record is as follows:

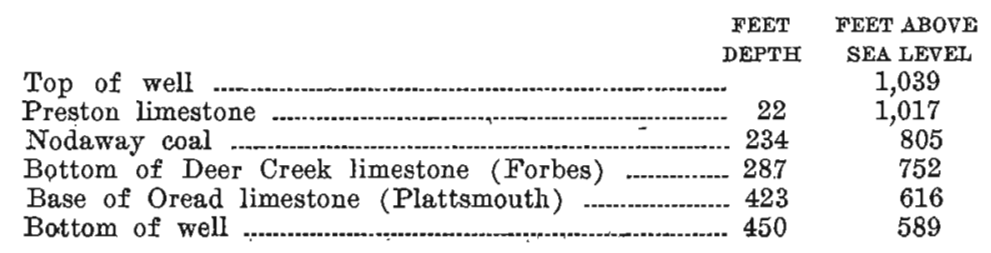

The record of the diamond drill hole at Clarinda, given in volumes XII and XXI of the Iowa Geological Survey and interpreted and treated more at length by Smith in volume X.IX, pages 618 to 620 , is considered especially reliable. On comparison with the record at Coin a comparatively rapid rise of strata along the line chosen is noted, amounting to 16it feet in eight miles for the base of the Oread (Plattsmouth) limestone, and 149 feet for the horizon of the Nodaway coal, the eastern boundary of which is within two miles to the east of the well. A diminishing thickness of the Oread limestone is noted on comparison with the record at Nebraska City, provided the latter record does not include thin shaly beds with the limestone. A condensed record of the Clarinda hole is as follows:

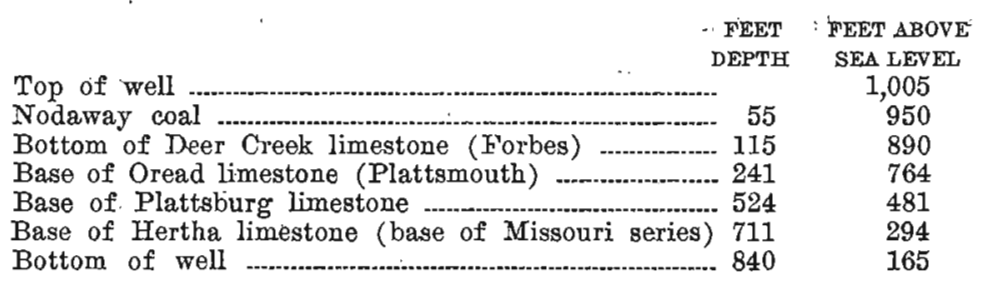

The record, with interpretation by Smith, of the diamond drill hole at College Springs is given on pages 628 and 629 of volume XIX, Iowa Geological Survey. This well is located ten and one-half miles in a direction south twenty-five degrees west from the well at Clarinda. If the horizon of the Nodaway coal is placed on the line marking the position of the Nodaway coal as determined at Coin and at Clarinda the records of the Deer Creek and Oread limestone beds also fall into their respective places in the diagram, The well is so far to the south that a use of the record other than for confirmation seems impossible at present. The line on which the record is 
placed is also of value to determine the general level at which the Nodaway coal may be found should it be desirable to shaft for it. A condensed record of the well is as follows:

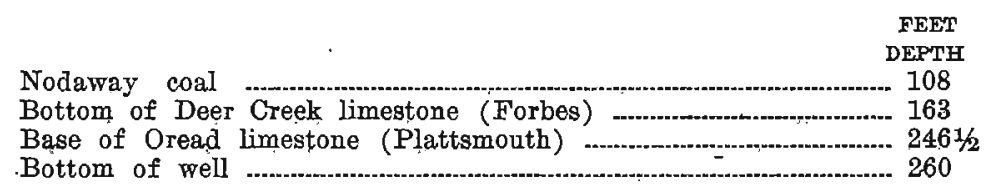

Doctor Smith reports that he finds the strata along Nodaway river south from Clarinda to have an average slope about equal to the slope of the river but in the opposite direction, ${ }^{68}$ so that the Nodaway coal comes up to the river bank at Shambaugh. Seven miles northeast from Clarinda it appears again at Hawleyville. At both Hawleyville and Braddyville are small anticlines, with a syncline between, over which Clarinda is situated.

The record of the deep well at Bedford may bes found in volume XXI of the Iowa Geological Survey, pages 1183 to 1185. Between Clarinda and Bedford, a distance of fifteen miles, the Deer Creek and Oread limestones each rise 168 feet, about half the rise per mile which is found between Coin and Clarinda. The limestone at a depth of 645 feet appears to be the Hertha limestone, at the base of the Missouri series (instead: of the limestone at a depth of 760 feet, as given in the report). A condensed record of the well at Bedford is as follows:

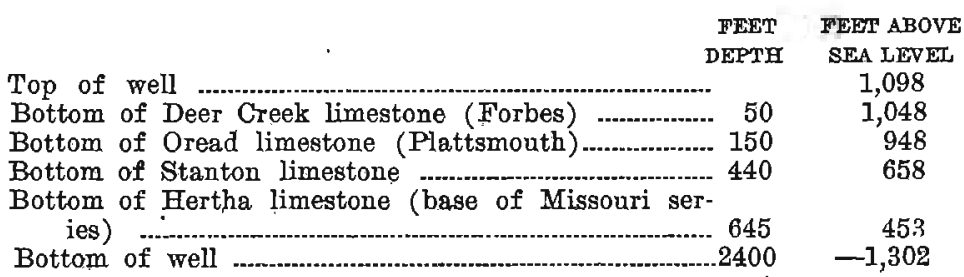

Between the valley of the East Fork of One Hundred and Two river at Bedford and the valley of Grand river in Decatur county there are no exposures of stratified rock near the line of the cross section, and at present no records of deep wells, though it is reported wells have been put down through the

63G. L. Smith, Carboniferous Section of Southwestern Iowa: Iowa Gool. Survey, Vol. XIX, p. 624, also Calvin, Geology of Page County: Iowa Gool. Surrey, Vol. XI, p. 427. 


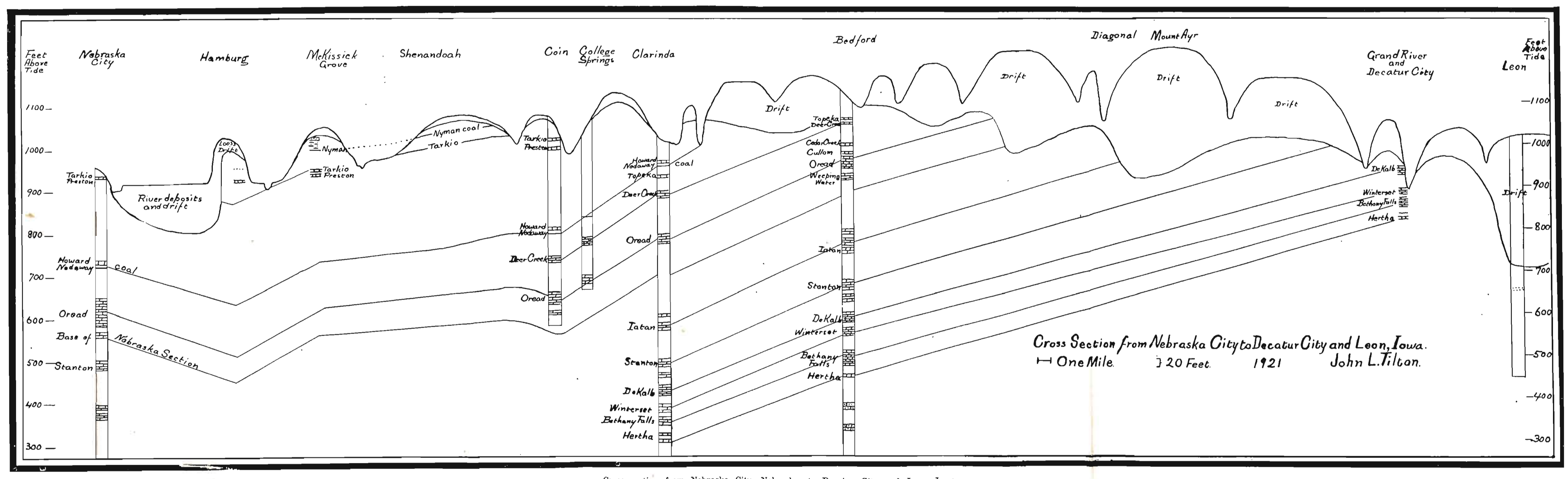

Cross seetion from Nebraska Cily, Nebraska, to Deeatur City and Leon, Iowa 
glacial drift. Somewhere beneath the thick drift of this region the Oread, Iatan and Stanton limestones come to the preglacial surface. Records in western Madison county and eastern Adair indicate that this portion of the Missouri series is thinner and less calcareous toward the east. Apparently the Oread limestone is nearest the surface near Cleartield, and the Iatan limestone is nearest the surface near Diagonal, where some evidence of its presence may be found along the valley of the West Fork of Grand river in Ringgold county. Apparently the few small exposures in sections 23 and 24, Lots Creek township, Ringgold county, are of Stanton limestone. A preglacial valley three hundred feet deep is reported in a well record at Mount Ayr, a location which corresponds to that of a preglacial valley eroded in the Vilas shale. The presence of such a valley is the occasion for the representation of another parallel valley seven miles west of Diagonal, where the Lawrence shale was subject to preglacial erosion. Eastward, at the end of the cross section, the record of the deep well or prospect hole at Leon locates another preglacial valley where the drift is three hundred and five feet deep. ${ }^{84}$

The cross section really ends at the bridge across Grand river three and one-half miles west of Decatur City in Decatur county, but the drawing is extended to include the evidence of a preglacial valley given in the record of the deep well at Leon, east of the area of the Missouri series. The top of the Winterset limestone at the bridge west of Decatur City is taken as being the stratum which is six feet above the level of low water in Grand river (890 feet above sea level), and the other strata of the Kansas City stage of the Missouri series, all of which up to and including the De Kalb limestone are found along the river within the county, are represented in their proper positions.

\section{The Cross Section along Grand River, with Extension to Middle River.}

The cross section along Grand river extends twenty-eight and three-fourths miles from Davis City, Decatur county, past

64In this connection one should not overlook Keyes's description of the Cap-au-Gres fault: Proc. Iowa Acad. Sci. Vol. XXIII, p. 104. No evidence of the extension of it through the area here studied has been found. An anticline is mentioned in the discussion of structure. 
the town of Grand River, to Afton Junction, Union county, which three points afford opportunity to determine the level of the river bed above sea level.

$$
\begin{aligned}
& \text { At Davis City: - FEET } \\
& \text { Level of the Chicago, Burlington and Quincy railroad sta- } \\
& \text { tion, Gannett's Dictionary of Levels, above sea level.... } 914 \\
& \text { Bed of river below railroad station, by barometer............... } 32 \\
& \text { Level of the river at Davis City, above sea level.................. } 882 \\
& \text { Bridge at the town of Grand River, above sea level................... 971.4 }
\end{aligned}
$$

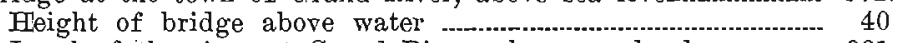

$$
\begin{aligned}
& \text { Level of the river at Grand River, above sea level …......... } 931.4 \\
& \text { Afton Junction, level above sea level of the Chicago, Burling- } \\
& \text { ton and Quincy railroad station, Gannett's Dictionary of }
\end{aligned}
$$

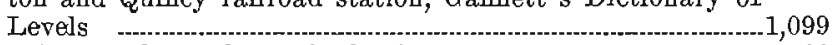

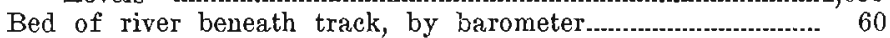

$$
\begin{aligned}
& \text { Level of river at Afton Junction, above sea level......................,039 }
\end{aligned}
$$

In this distance the total fall of the river is 157 feet, or 5.46 feet per mile, the gradient of the stream being uniform except for the effect of bends in the course of the stream, of a small dam about four feet high at Westerville, and of a similar one at Davis City. The general direction of the stream approximately parallels the eastern margin of the Missouri series in this part of the state, in which there is a rise in strata toward the northeast of about twenty-five feet in Decatur county and of one hundred and sixty feet from Davis City to Winterset. The cross section along Grand river may be extended northward to join the cross section along Middle river at Brushy branch between Madison and Adair counties, beyond which to the north the cross section along Middle river approximately parallels the eastern margin of the Missouri series.

At Davis City the base of the Bethany Falls limestone is about ten feet above the river, or 872 feet above sea level. This is taken as the starting point of the cross section. There is a part of each formation exposed within two miles southwest from Davis City, but not sufficient to make a complete composite section:

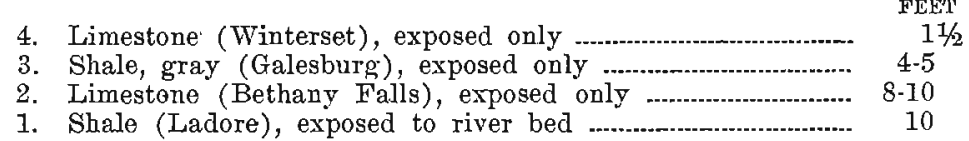

Five miles up the river from Davis City there is the crest of a small anticline, as described by Bain in his report on Decatur county (Vol. VIII, Iowa Geological Survey) that seems to line 
up with the anticline at the bridge three and one-half miles west of Decatur City, where a dip of $9^{\circ} 35^{\prime}$ is to be found in the Winterset limestone. The overlying De Kalb limestone near by dips $3^{\circ} 10^{\prime}$ in a direction S. $73^{\circ} \mathrm{W}$. (In the chapter on Structure may be found a discussion of the relation of an unconformity here to a disconformity in the northern and western portions of the area under consideration). There are minor variations, but in general the rise of the strata in the direction of the cross section is uniform.

The section at Decatur bridge as described by Bain $^{65}$ is as follows :

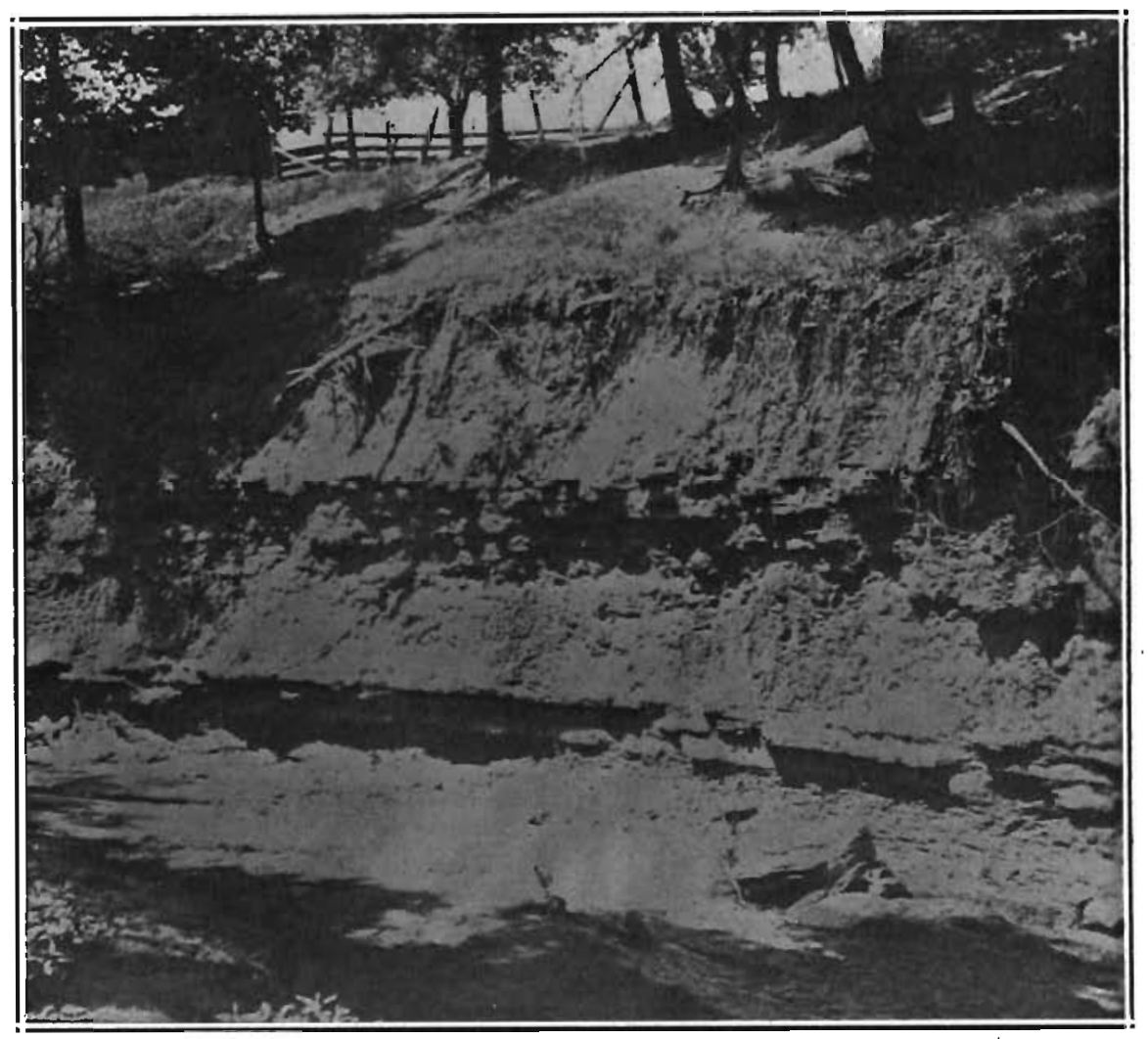

FIG. 38.- The base of the DeKalb limestone above the Cherryvale shale in a side ravine near the mou'h of Sandy cneek, Westerville. The Westerville limestone is weathered away from just above the face of the cliff but appears on the hillside close by. (Townfrom just above the face of the cliff but appears on the hillside close by. (Town-
ship 7.0 Nortl, Range XXVII West, Southeast qualter of the Southwest quarter of

65H. F. Bain, Geology of Decatur County: Iowa Geol. Survey, Vol. VIII, pp. 278-279. 
5. Limestone, lower ledges only

FEET (De Kalb limestone)

4. Shale, drab to black; Chonetes verneuilianus, Composita subtilita, Orthotetes crassus, Prodnatus nebrascensis, Myalina subquadrata, Rhombopora lepidodendroides, Lophophyllum proliferum and Eupachyorimus verucosus (plates). There are thin ledges of limestone made up of Chonetes vernevilianus

3. Limestone, blue to black; Composita subtilita, Productus cora, $P$. nebrascensis

2. Shale, drab, clayey (Cherryvale shale, thickness, 30 feet.)

1. Limestone, coarse bedded; Composita subtilita, Productus costatus, Meekella striatocostata (Winterset limestone). To bed of river

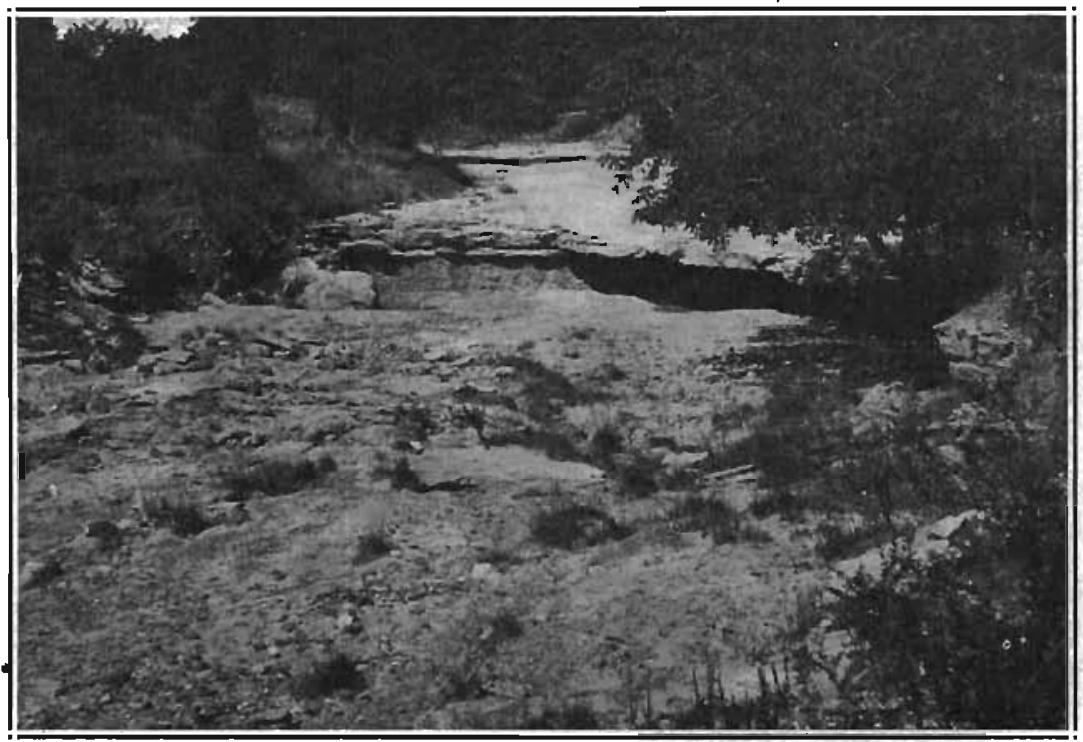

Fra. 39.-The top of the DeKalb limestone (Westerville) in the bed of Sandy creek near Westerville, Deeatur county. (Township 70 north, Range XXVII west, east center of section 20.)

The full section as above described is not now visible, as the filling in around the west end of the bridge has concealed a portion of the upper shale.

Upstream from the section at the bridge west of Decatur City the next section used is obtained by combining the outcrop at Westerville with those a short distance up Sandy creek, where Bain's Westerville limestone is exposed in the bed of the creek, from the center of section 21 to the center of 
section 20, Township 70 north, Range XXVII west. The section is as follows:

9. Limestone, dark gray; Fusulina cylindrica, spines of echinoids, Naticopsis, Euomphalus (DeKalb limestone)

8. Shale, gray, nonfossiliferous

7. Shale and limestone alternating, Meekella striatocostata zone in center; Produotus nebrascensis

6. Shale, dark blue, nonfossiliferous, carbonaceous...-.....

5. Limestone, in three or four divisions, irregular shaly partings, very fossiliferous; Chonetes verneuilianus, Composita subtilita, Productus nebrascensis, $P$. cora, Spirifer cameratus, Fenestella, crinoid stems

4. Shale, dark blue, nonfossiliferous .......................... lower half, which is in two parts .....................

2. Shale, blue, clayey

1. Not fully exposed to river at low water, but about a foot is limestone at river .................................. (Cherryvale shale, thickness, 28 feet, 3 inches)

\begin{tabular}{cr} 
FEET & INCHES \\
6 & \\
8 & \\
3 & 8 \\
3 & \\
& \\
& \\
1 & 9 \\
2 & 2 \\
2 & 8 \\
5 & 6 \\
1 & 6 \\
\hline 34 & -3 \\
\hline
\end{tabular}

The above correlation, which is contrary to that of Bain, ${ }^{68}$ is discussed under the head of Nomenclature.

The topmost limestone in the above section (Bain's Westerville) also outcrops at the level of Grand river at a ford (section 36) and at a bridge over Grand river directly west from Hopeville in the south center of section 11, both in Pleasant township, in the southeastern part of Union county ${ }^{67}$; and from two to three miles in a straight line northwest from the bridge mentioned may be found other sets of beds of limestone: sections 34,33 and 28 of Jones township (Township 72 north, Range XXVIII west). A section in the southeast quarter of the northeast quarter of section 33 is as follows:

9. Limestone, grayish brown, in beds from three to

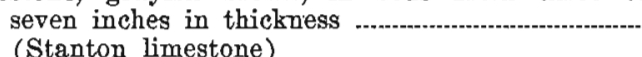

8. Not exposed

FEET INCHES

7. Limestone, $31 / 2$ inches

6. Shale, 1 inch

5. Limestone, 3 inches

4. Shale, 6 inches

3. Limestone, 5 inches (Plattsburg limestone) 2. Shale, greenish

1. Not exposed, to river at low water

$\begin{array}{cc}8 & 6 \\ 1 & 7 \\ 1 & 61 / 2 \\ 1 & 6 \\ \frac{26}{39} & \frac{6}{7}\end{array}$

66H. F. Bain, Geology of Decatur County: Iowa Geol. Survey, Vol. VIII, pp. 276-278. B7John L. Tilton, Geology of Clarke County: Iowa Geol. Survey, Vol. XXVII, pp. 132-134. 


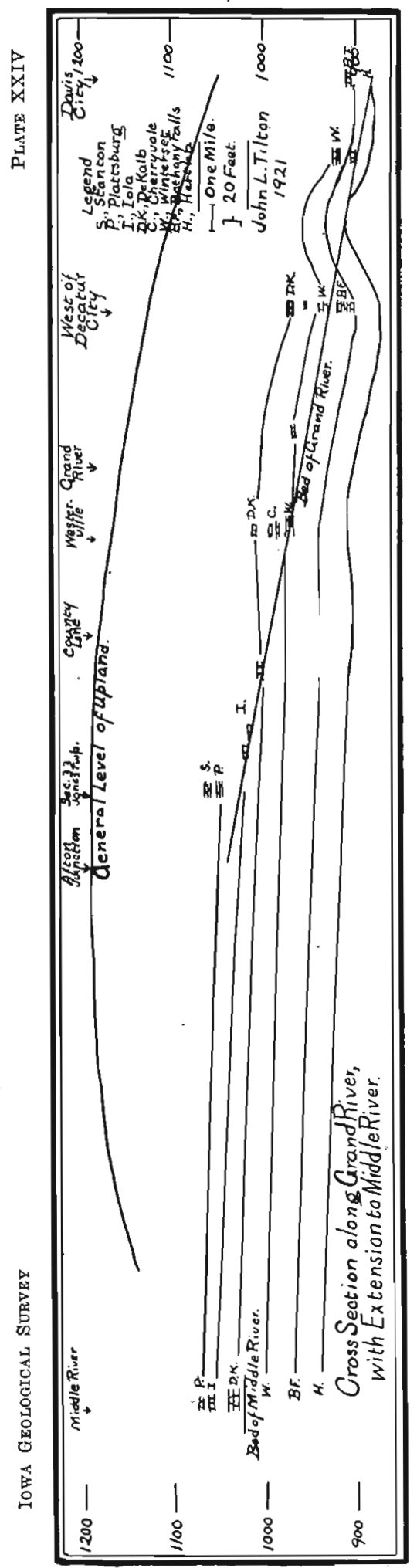

The cross section along Grand river as drawn in beneath the river at Afton Junction may be connected with the cross section along Middle river by means of the section along Brushy branch close to the west line of Madison county. The only exposure of stratified rock from Afton Junction to the beds exposed along Middle river is one four miles north of Macksburg and only a mile and a half from Middle river. It is in the northeast quarter of the northeast quarter of section 27 and the southeast quarter of the southeast quarter of section 22 of Township 75 north, Range XXVIII west, where the De Kalb limestone appears near the bed of the creek. In a direct line between Afton Junction and Brushy branch all the rock is deeply concealed beneath drift, and there are no records of deep wells.

资

\section{The Cross Section along Middle River.}

The cross section along Middle river extends twentyeight miles from Winterset, Madison county, to the southwest quarter of the southwest quarter of section 16, Jefferson township, Adair county, not far from Stuart. From Winterset for a distance of eight and one-half miles the various outcrops are re- 
ferred to river level at right angles to a line extending N. $75^{\circ}$ $\mathrm{E}$., which is the general direction in which the river flows in that part of its course. Above this point (southwest quarter of the southwest quarter of section 14, Webster township) the general direction of the river is S. $38^{\circ}$ E., to which direction the various outcrops are referred.

South of Winterset the elevation of the river above sea level is 927 feet. At section 16, Jefferson township, Aidair county, the elevation is $\mathbf{1 1 3 5}$ feet, giving a total fall of 208 feet, an average of 7.43 feet per mile. From a point five miles west of Winterset to a point seven miles still farther west along the line representing the general course of the stream the regularity of the slope is interfered with by limestone fragments that have accumulated at the mouths of ravines, causing the river at low water to change in level by successive steps from one pool of quiet water to the next, between which are stretches of rapid water. The regularity of slope along the general direction of flow is also interfered with by the presence of numerous large bends, some of which are distinctly meanders. To some extent, at least, these successive steps in this part of the course tend to change the general shape of a stream (concave upward) into a slope that is more nearly that of a straight line than would be the case if the small rapids did not exist. There has been a small dam at Port Union mill, but what there is left of it offers little obstruction to the stream at low water. Between the two extremes there is no chance to ascertain the amount of departure of the gradient of the stream from the average, except by repeated trips with barometer.

A more serious difficulty than that due to deposits of fragments of limestone, which tend to improve the general gradient, and that due to large bends, which partly equalize themselves, is one dependent on the dip of the strata, for which allowance should be made in examining the cross section. The general dip is toward the southwest, at an angle with the course of the river. When records from ravines on the south side of the river are placed near records made on the north side of the river, followed again by a record from the south side of the river, and all referred to the level of the stream, the result in 
a drawing resembles an anticline, magnified, of course, by the scales used. Records taken first north, then south, then north again, make a drawing resemble a syncline. The same principle applies when measurements near the river are compared with measurements taken at some distance from the river. Such results may be found in the cross section at points ten miles and fourteen miles west of Winterset. Such a representation is deceptive; yet, since correlation rather than structure is here desired, it is thought better to place the individual sections just as they were measured than to attempt to allow for the effect of the.dip. There is a slight anticline where the diagram represents one, but not nearly of the magnitude the diagram represents. In the entire region the dip is slight. Measurements are given in the discussion of structure.

The cross section along Middle river is of peculiar value. It gives the relation of the strata from the Hertha at the base of the Kansas City stage near Winterset to the highest strata of the Missouri series found east of the state divide. From its northwest end there are but seven miles across the drift in the region of the Thurman-Wilson fault to the shales and limestones three miles north of Stuart, long mapped as of Missouri age but in reality belonging far down in the Des Moines series.

The Middle river section approaches the section along Nishnabotna river and reveals in Harrison township, Adair county, the thin Oread beds that appear at Riverview park near Red Oak, Montgomery county, and also on Turkey creek at a point two miles northeast of Lewis, Cass county. Above the Oread in Adair county are other limestones (Deer Creek) that assist somewhat in the correlation with beds near Stennett, Montgomery county. The Middle river section, near the west Madison county line, also approaches the Grand river section from Davis City to Afton Junction.

The region around Winterset is historical geologically. Here White spent a couple of weeks in study of local conditions preparatory to the publication of his report on the region. ${ }^{68}$.Here Calvin worked in his extensive studies, and here Bain and Tilton accumulated data for the report on Madison county, to be

88Charles A. White, Report on the Geological Survey of Iowa: Vol. 1, pp. 241-250 and 305-309. 
found in volume VII of the present series. This location is chosen for the first portion of the section along the river, though the Hertha may be found farther east even to St. Charles. Where the road southwest from Winterset turns up the river valley (southeast quarter of the northwest quarter of section 12) the Pleasanton sandstone with Hertha above it may be seen by the roadside. Along the ravine southeast from Winterset there is a complete section from the uppermost portion of the Hertha to the top of the Cherryvale shale. Fragments of De Kalb limestone are to be seen but no beds in place.

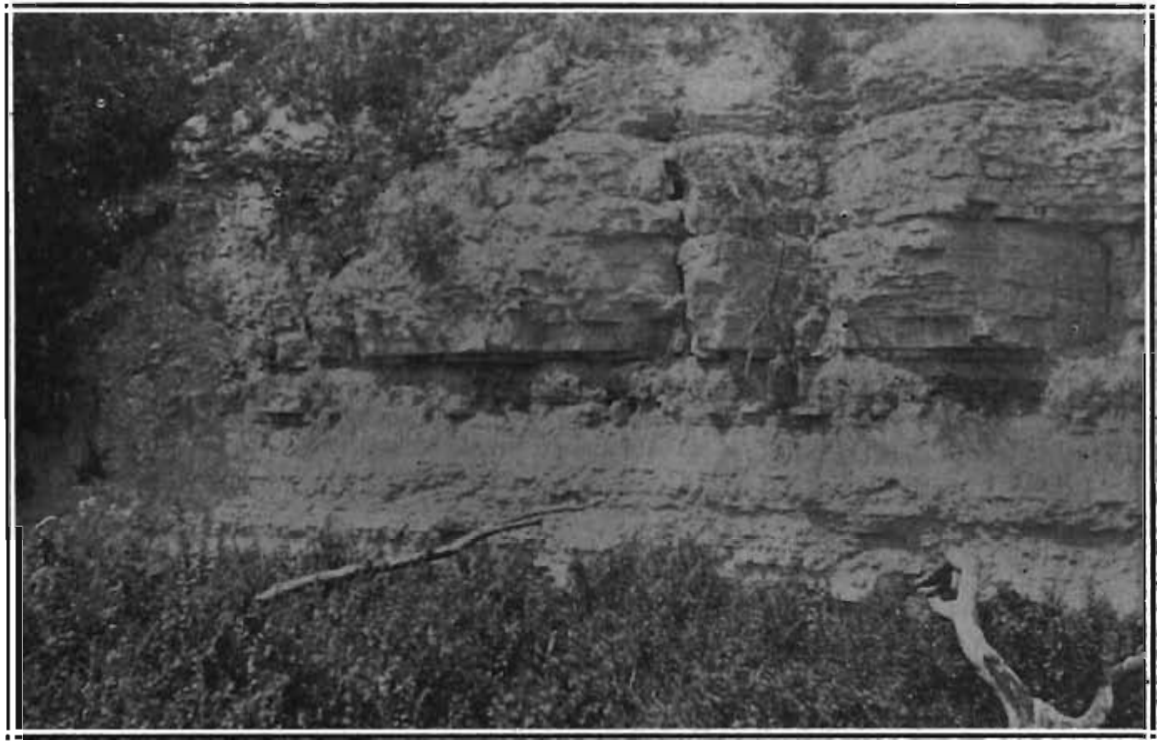

Fra. 40.- The Bethany Falls (Earlham) limestone in a ravine southwest of Winterset,
Madison county.

It is here that the following described section was measured:

THE SECTION AT WINTERSET

26. Drift to upland at (old) railroad station, 1,118

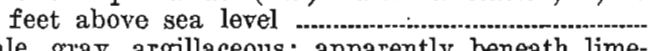

25. Shale, gray, argillaceous; apparently beneath lime-

24. Limestone, blue, in three layers with partings of

FEET INCHES shale, the so-called Myalina horizon in the Cherryvale shale, very fossiliferous: Myatina swallovi, Orthotetes (Derbya) crassus, Chometes verneuilianus

23. Shale, graty, argillaceous, with bed of Chonetes verneuilianus in upper portion (Cherryvale shale, thickness, 16 feet.) 


\begin{tabular}{|c|c|c|c|}
\hline & & FEET & INCEIES \\
\hline 22. & Limestone, gray, fragmental in upper portion ......... & 5 & 2 \\
\hline 21. & Limestone, gray, very resistant ledge; with chert.... & 2 & 3 \\
\hline 0. & Limestone, gray & 1 & 2 \\
\hline 19. & Shale, gray, argillaceous; Composita subtilita......... & & 3 \\
\hline 18. & 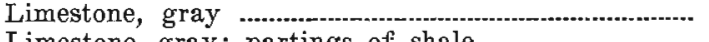 & 1 & 9 \\
\hline & $\begin{array}{l}\text { Limestone, gray; partings of shale } \\
\text { (Winterset limestone, thickness, } 13 \text { feet, } 10 \\
\text { inches.) }\end{array}$ & 3 & 3 \\
\hline 16. & Shale, gray, argillaceous & 1 & 6 \\
\hline 15. & Shale, black -- & 1 & 6 \\
\hline & $\begin{array}{l}\text { Shale, gray, argillaceous above, calcareous below.-...- } \\
\text { (Galesburg shale, thickness, } 10 \text { feet.) }\end{array}$ & 7 & \\
\hline 13. & 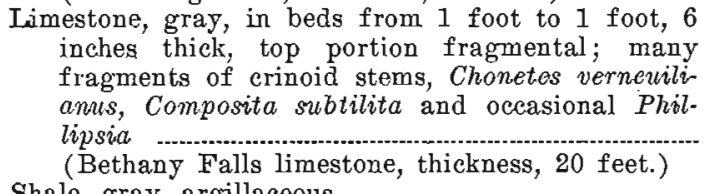 & 20 & \\
\hline 12. & Shale, gray, argillaceous ........................... & 2 & 10 \\
\hline 11. & Shale, black (seam of coal elsewhere) & 1 & 2 \\
\hline 10. & Limestone, dark blue ,... & & 8 \\
\hline 9 & $\begin{array}{l}\text { Shale, calcareous in places } \\
\text { Limestone, gray }\end{array}$ & 1 & 10 \\
\hline 8. & $\begin{array}{l}\text { Limestone, gray } \\
\text { Shale, gray, argillaceous }\end{array}$ & $\frac{1}{4}$ & $\begin{array}{l}5 . \\
9\end{array}$ \\
\hline 6. & Limestone, gray & 1 & 10 \\
\hline 5. & $\begin{array}{l}\text { Shale, gray, argillaceous } \\
\text { (亡́adore shale, thickness, } 21 \text { feet.) }\end{array}$ & 6 & 6 \\
\hline & Limestone; gray; Composita subtilita & 2 & 8 \\
\hline & 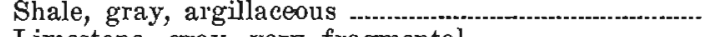 & 8 & 10 \\
\hline & $\begin{array}{l}\text { Limestone, gray, very fragmental } \\
\text { (Hertha limestone, thickness, } 16 \text { feet, } 6 \text { inches) } \\
\text { Not exposed, to river bed (but Pleasanton shale }\end{array}$ & 6 & \\
\hline & & 66 & 6 \\
\hline & & 164 & 10 \\
\hline
\end{tabular}

At a number of places between Winterset and the "Backbone" limestone and shale are visible from the road along the river. The next section used is along a ravine through sections 27 and 22 of Lincoln township.

15. Drift to the level of the upland, as at Winterset.-.

14. Limestone, gray; many Fusulina, Spirifer camerata, Syringopora

FEET INCHES

13. Shale, gray above; lowest 14 inches is blue

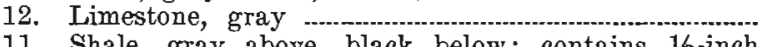

11. Shale, gray above, black below; contains 1/2-inch coal

10. Limestone, gray

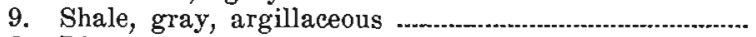

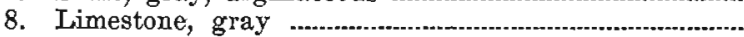
(De Kalb limestone, thickness, 16 feet, 9 inches.)

7. Shale (Cherryvale), with blue limestone as at Winterset; horizon of Chonetes verneuiliamus in shale below the blue limestone; blue limestone above marking horizon of Myalina swallovi and Productus cora 
6. Limestone (Winterset), thin layers above, thicker layers below, with shaly partings ..................... 14

5. Shale (Galesburg), black shale between two gray shales

4. Limestone (Bethany Falls), gray, in layers of various thicknesses up to a foot or so; top very fragmental

3. Shale (Ladore, with included limestone

2. Timestone (Hertha) with included shale.

1. Not exposed, from base of Hertha to Middle river

BEET INOHES

At the tunnel a mile up the river, where a mill was once located, the base of the Hertha is close to the level of the river ${ }^{68 \mathrm{a}}$; and across the river to the north may be found a duplicate of

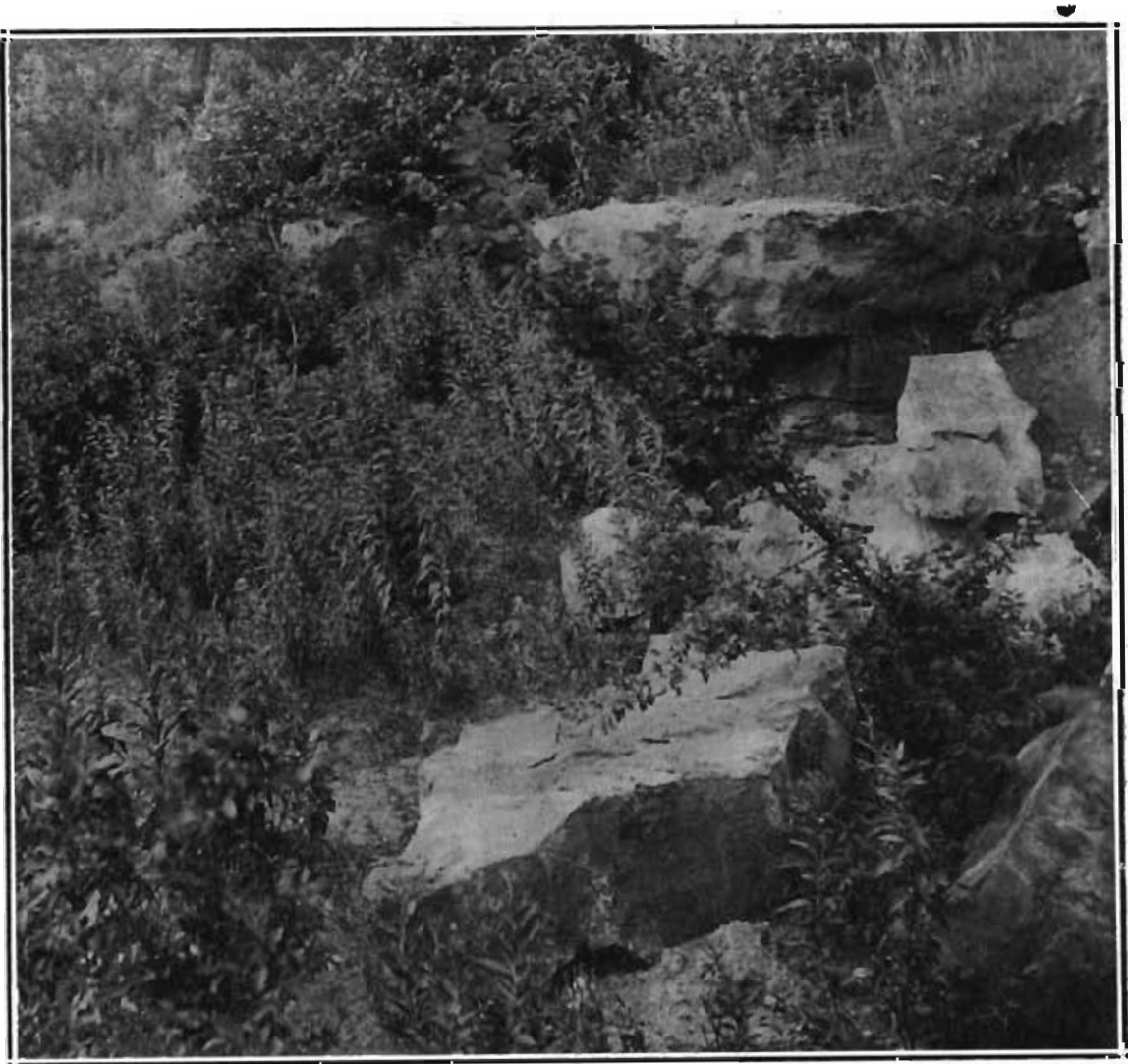

FIG. 41.- The Winterset limestone close to Winterset, Madison county, along road south from Winterset.

68a'This location is now chosen for a state peric 


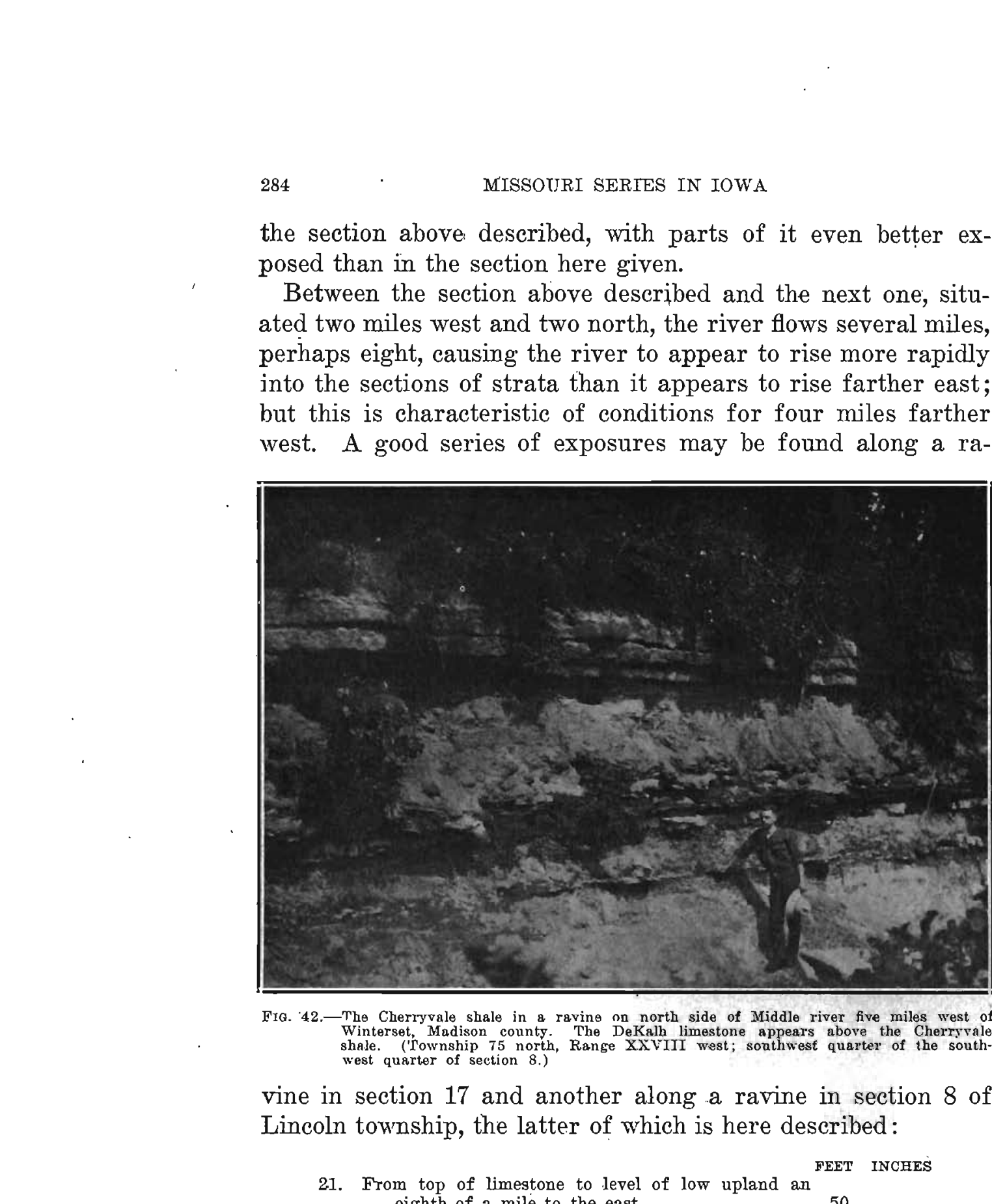

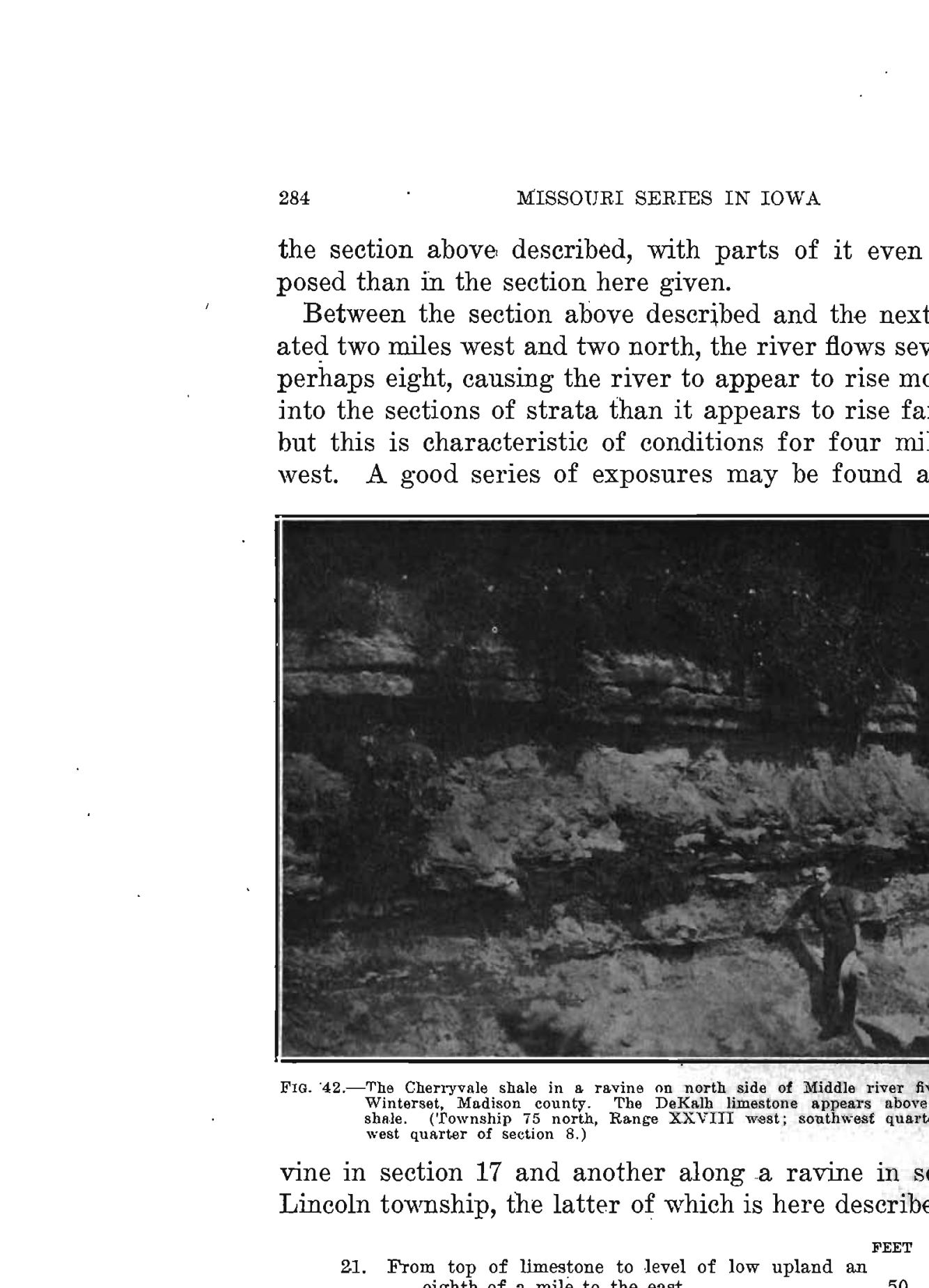

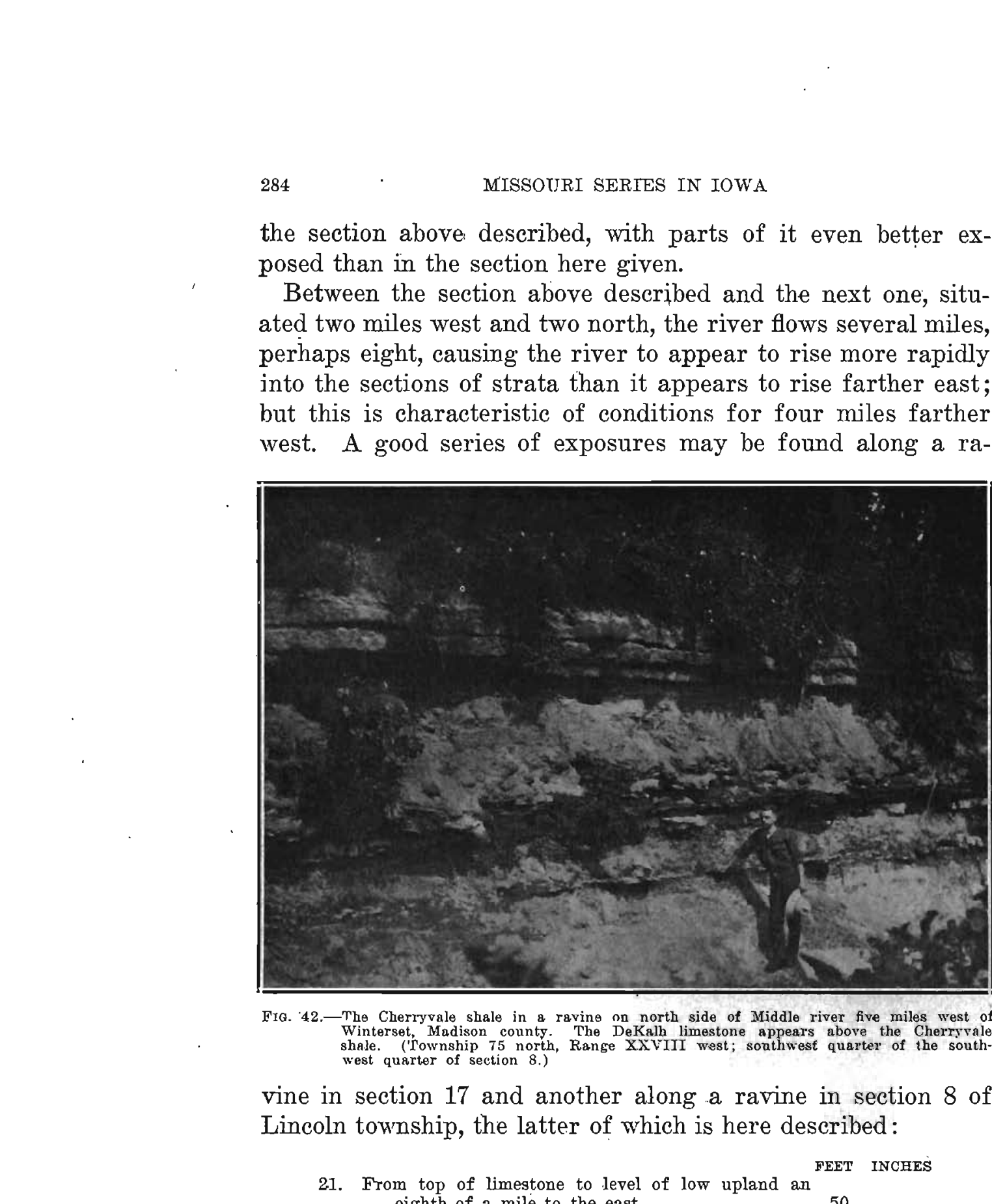

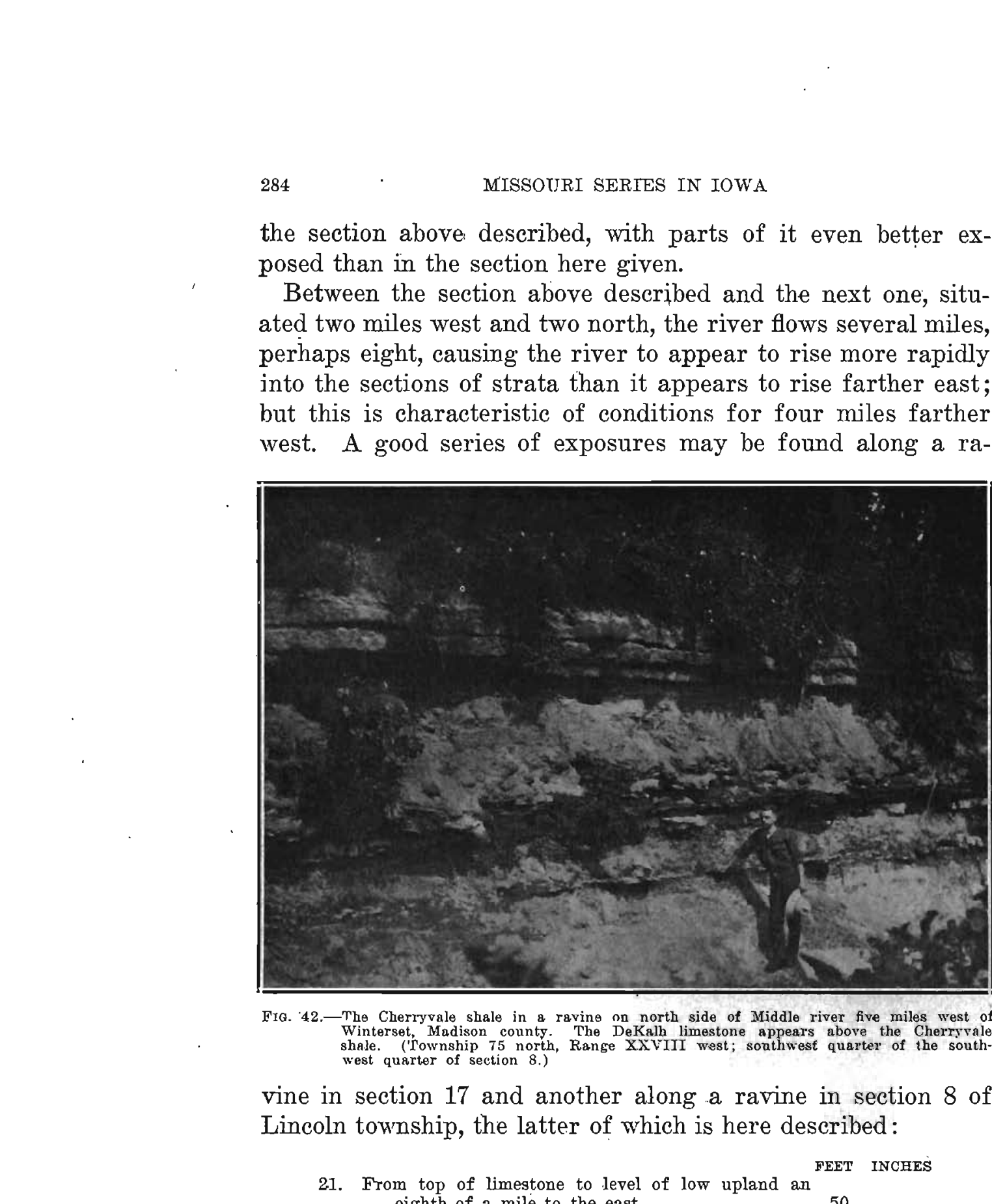

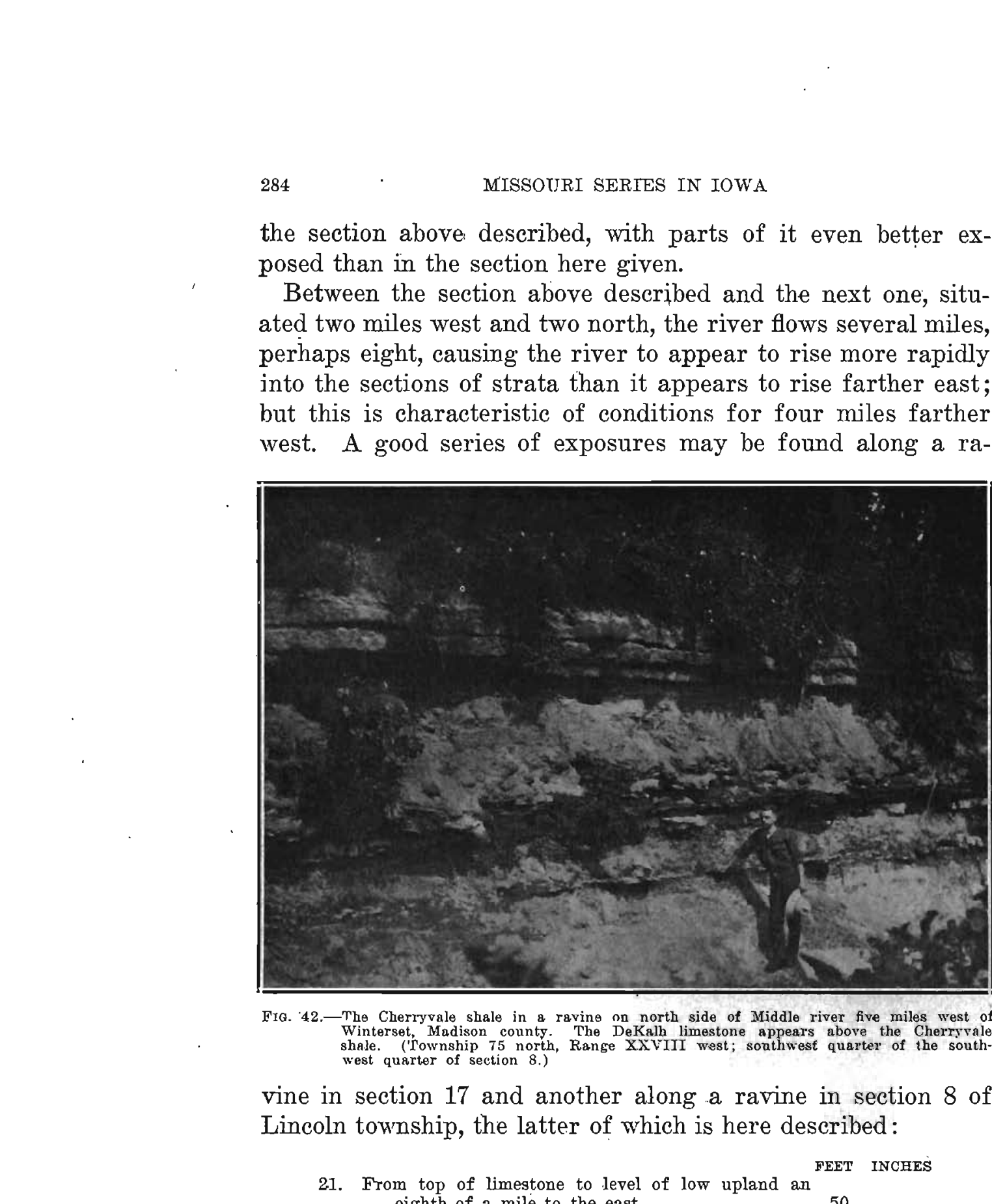

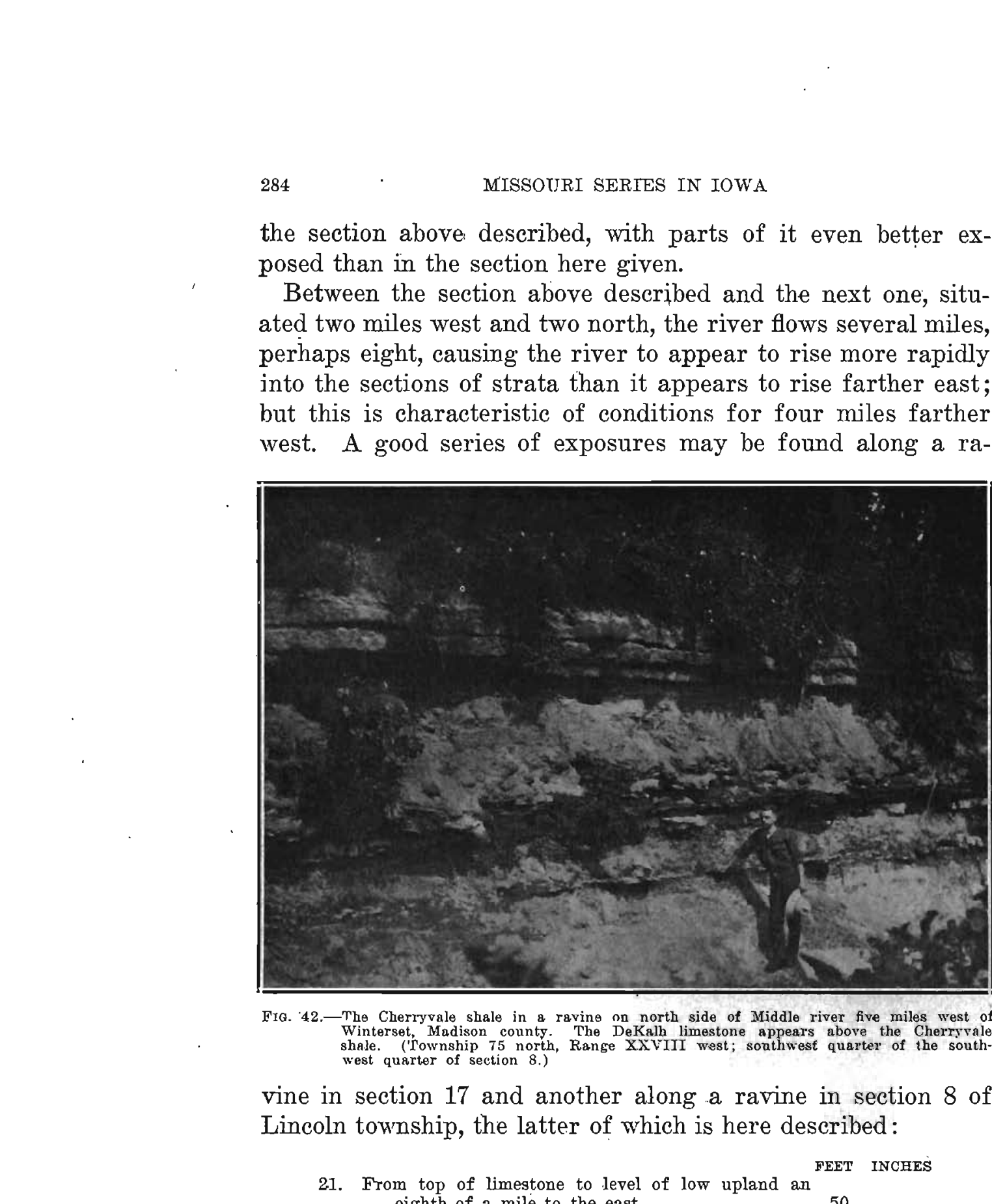

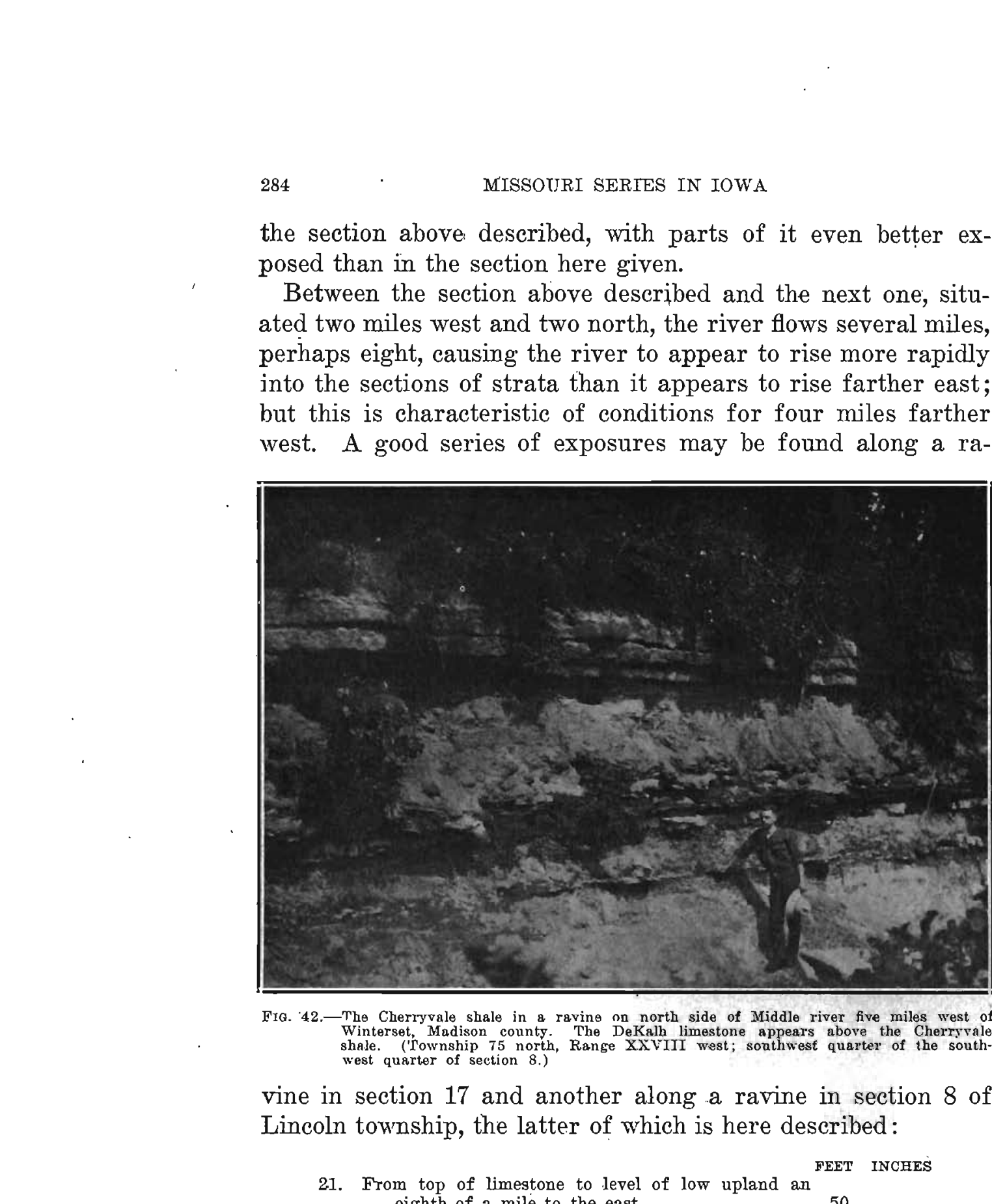

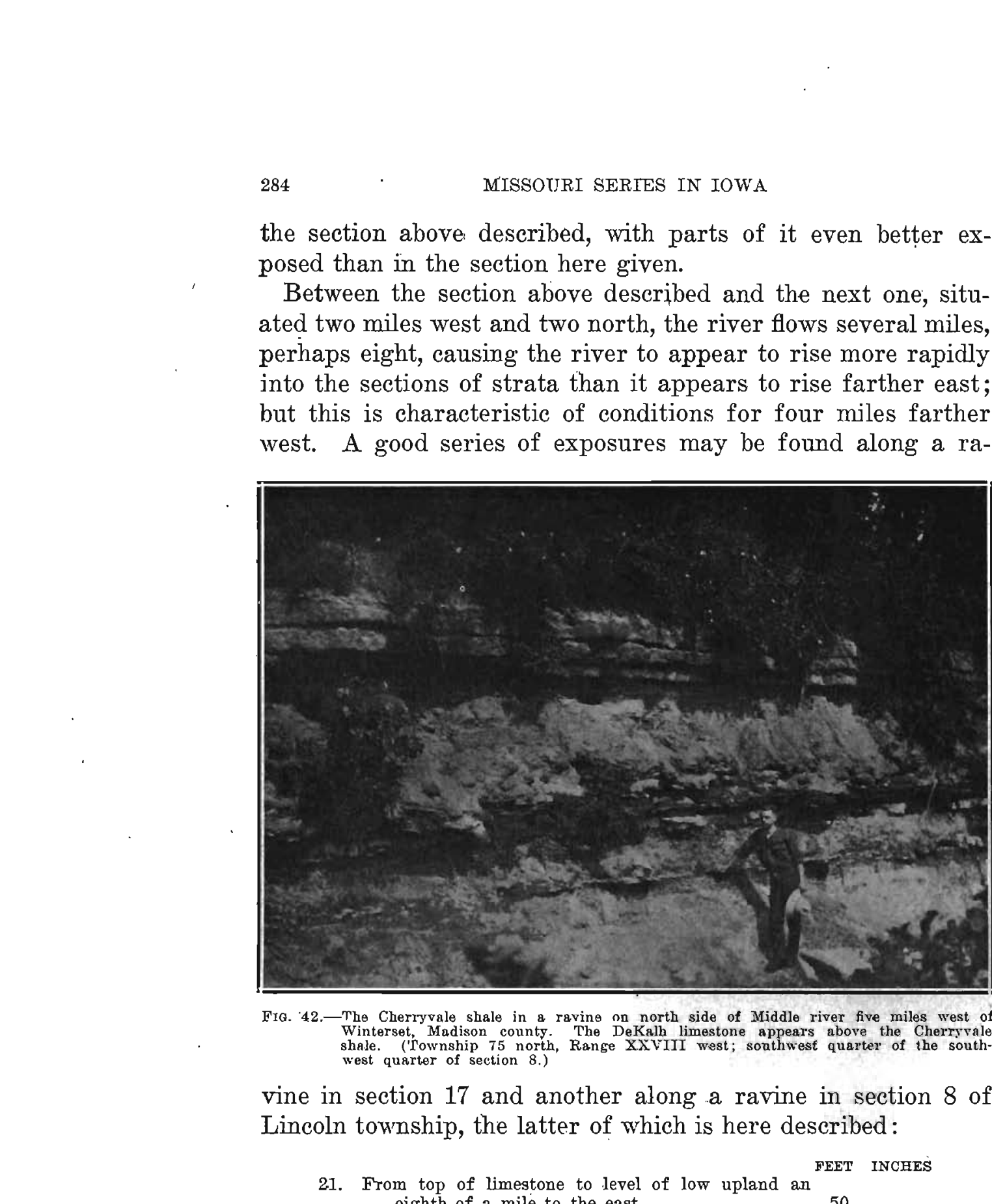

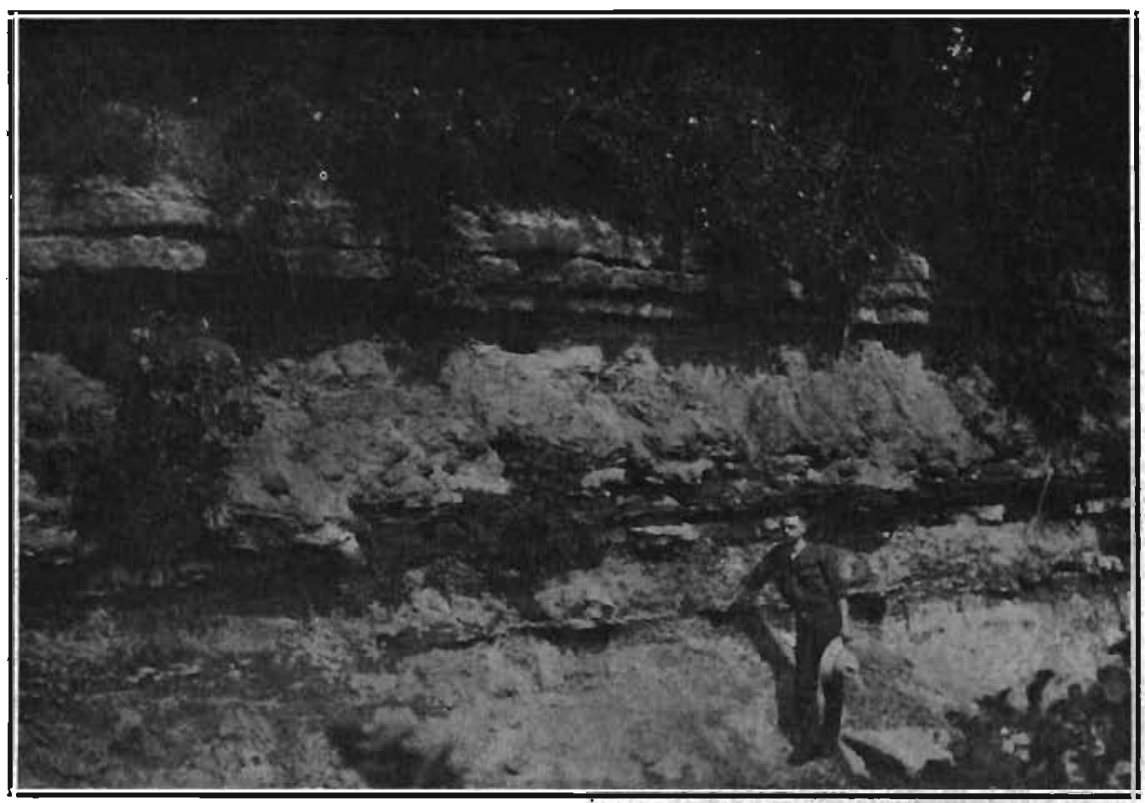

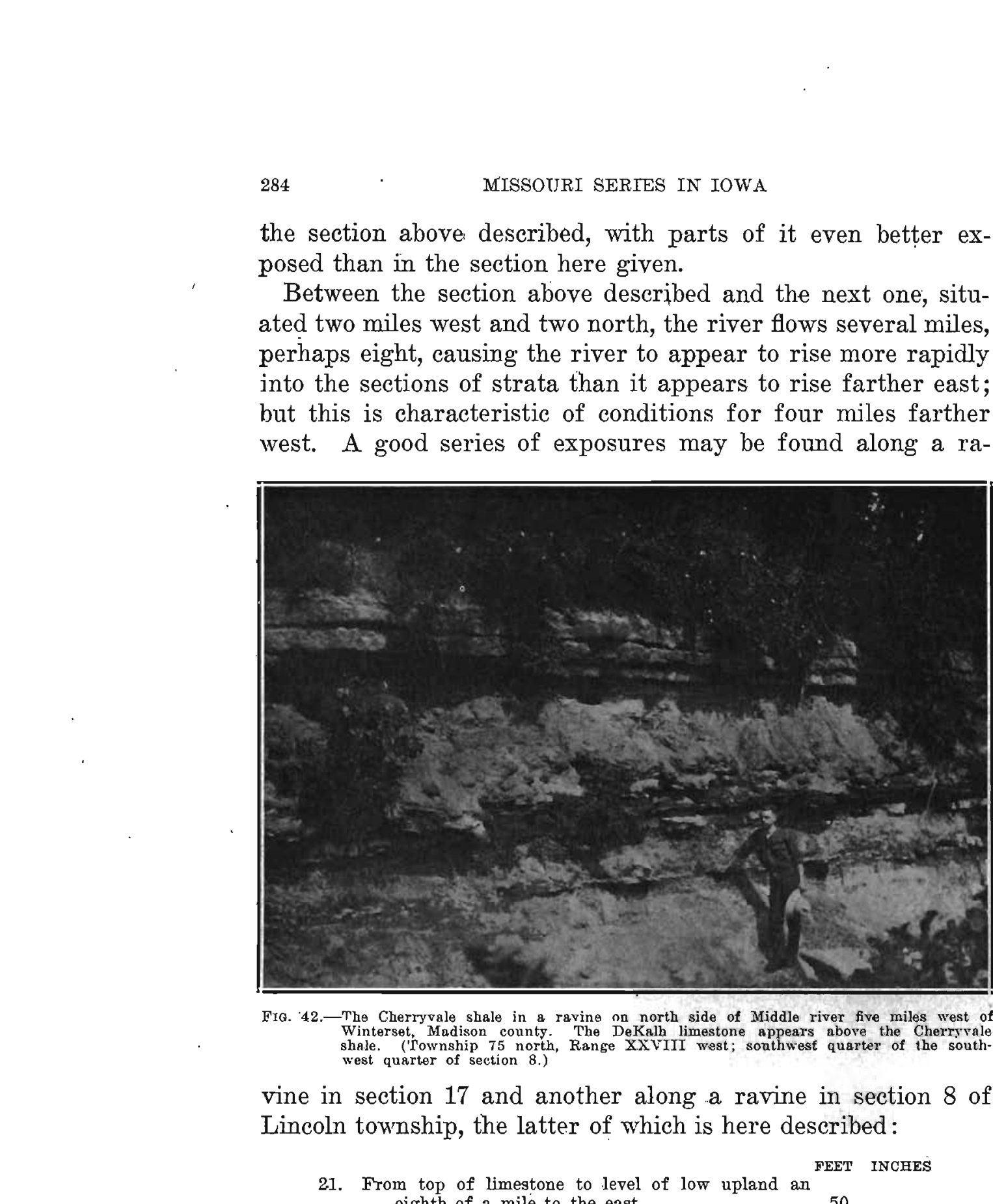

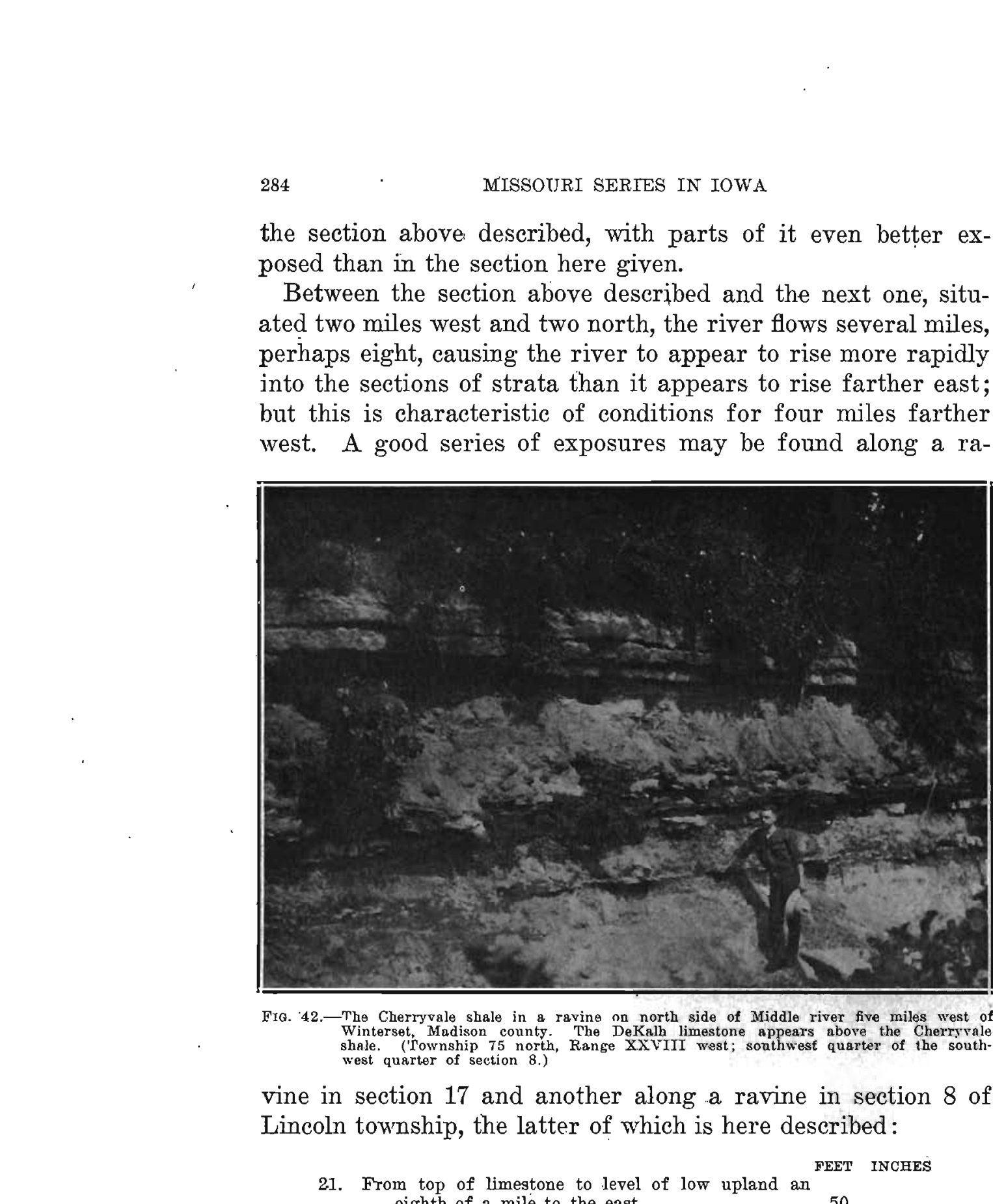

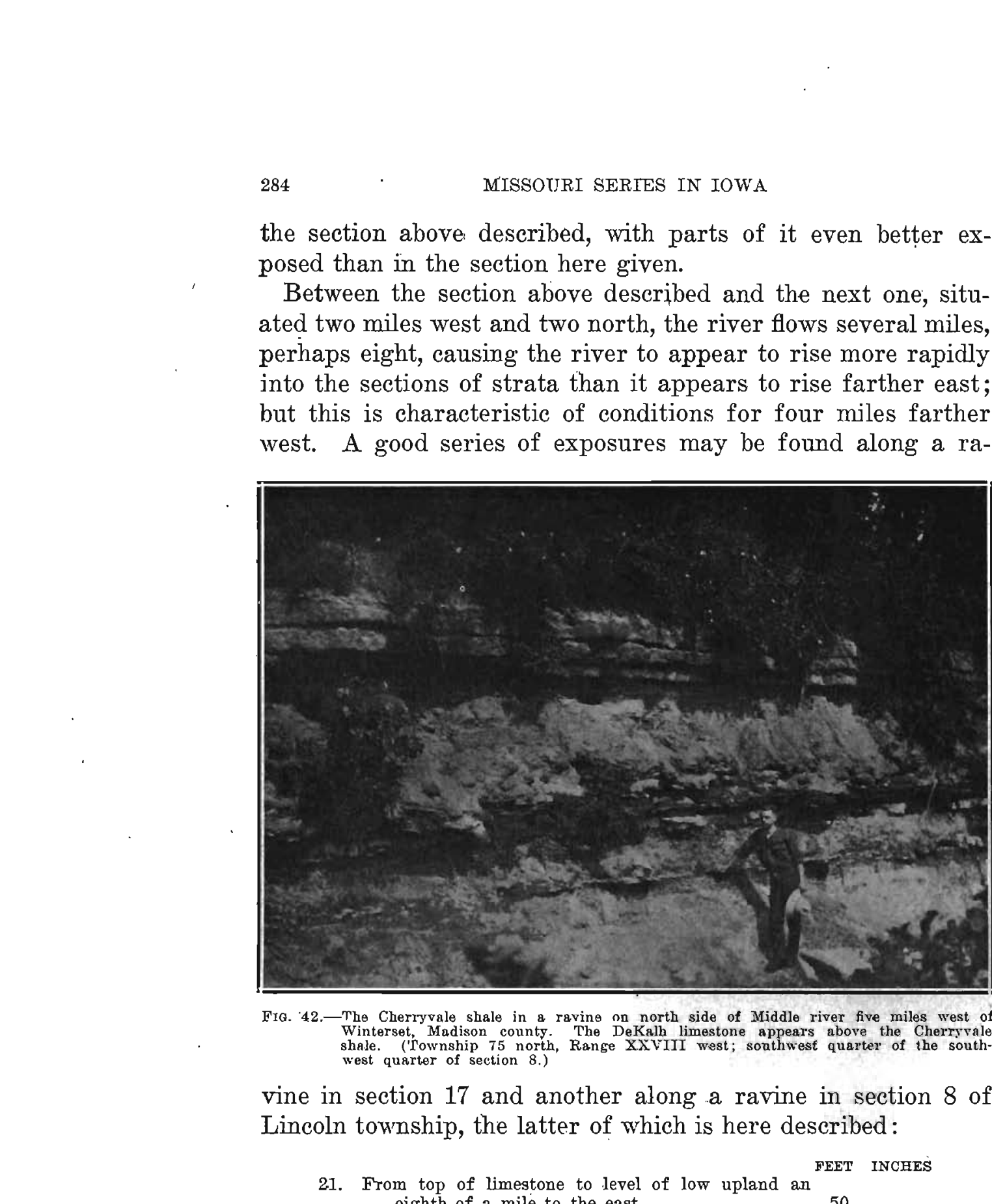

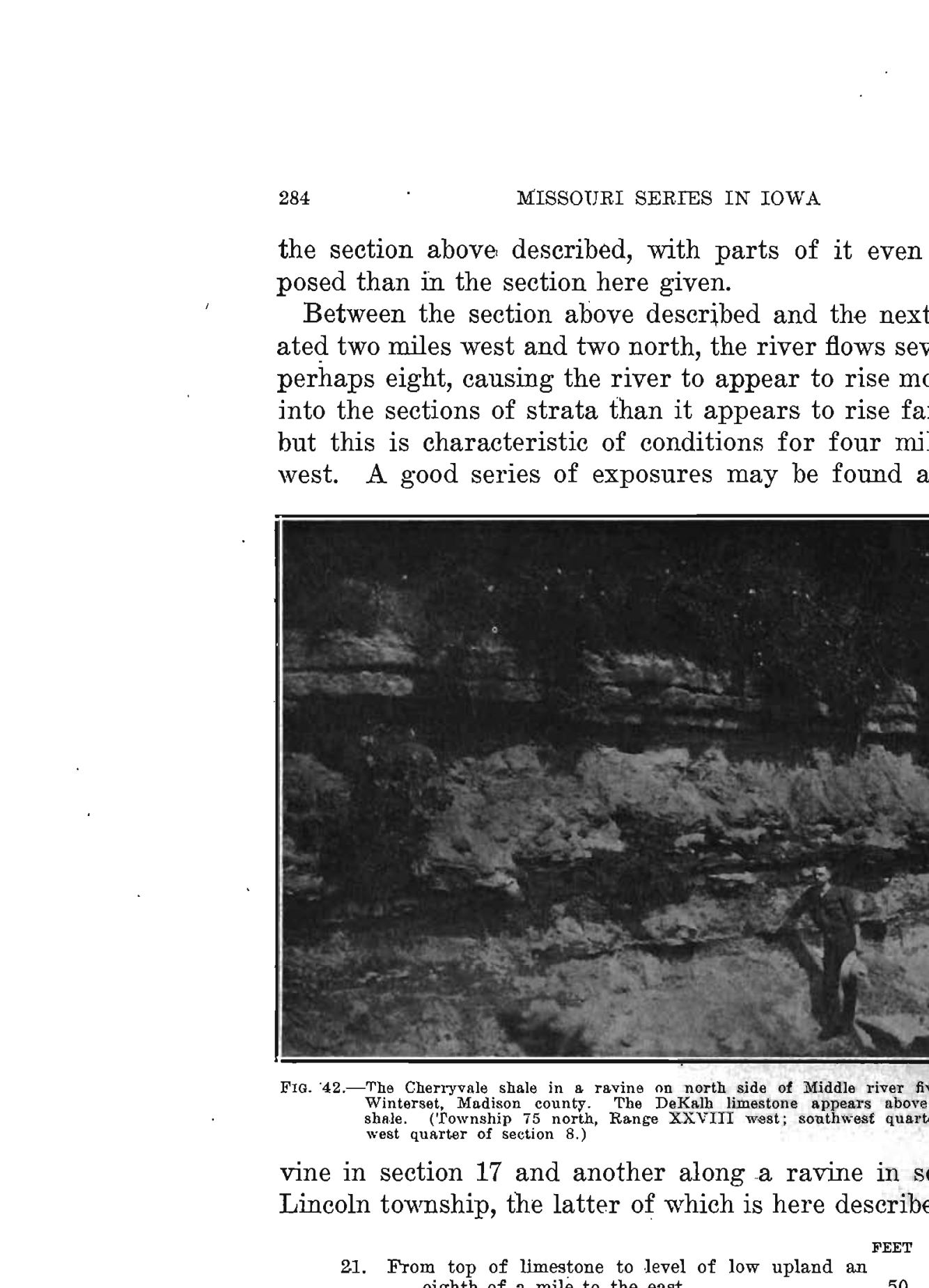

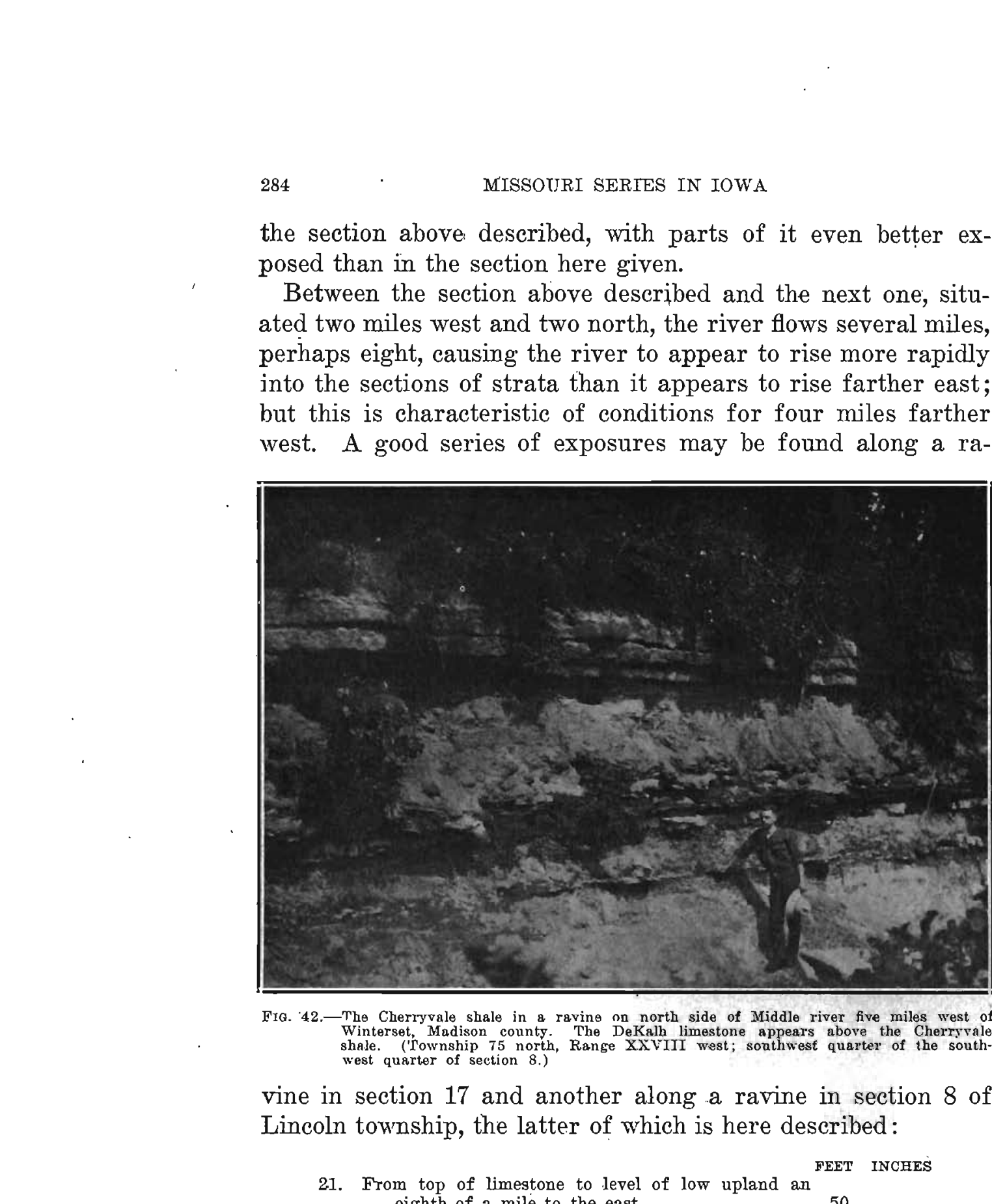

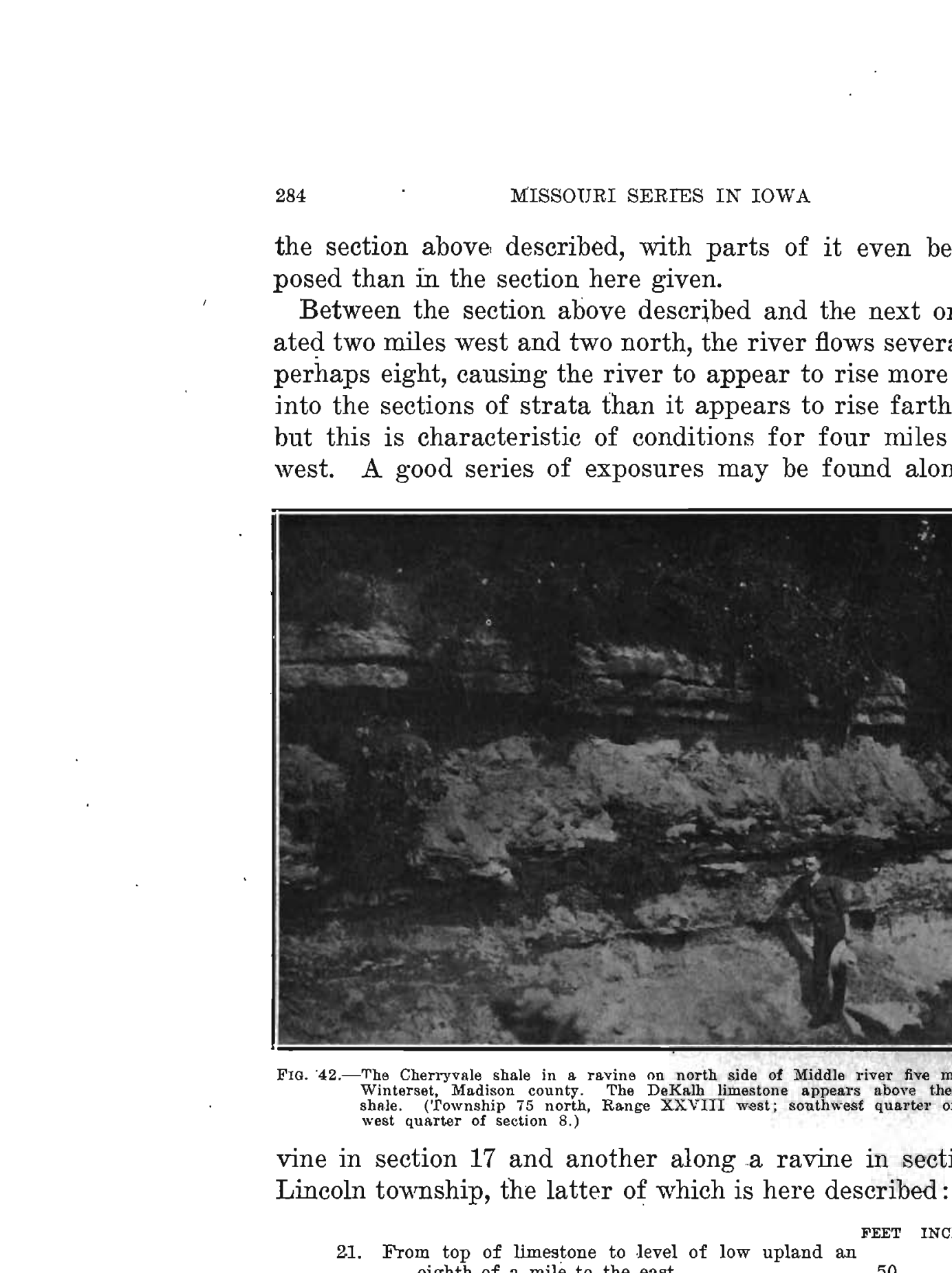

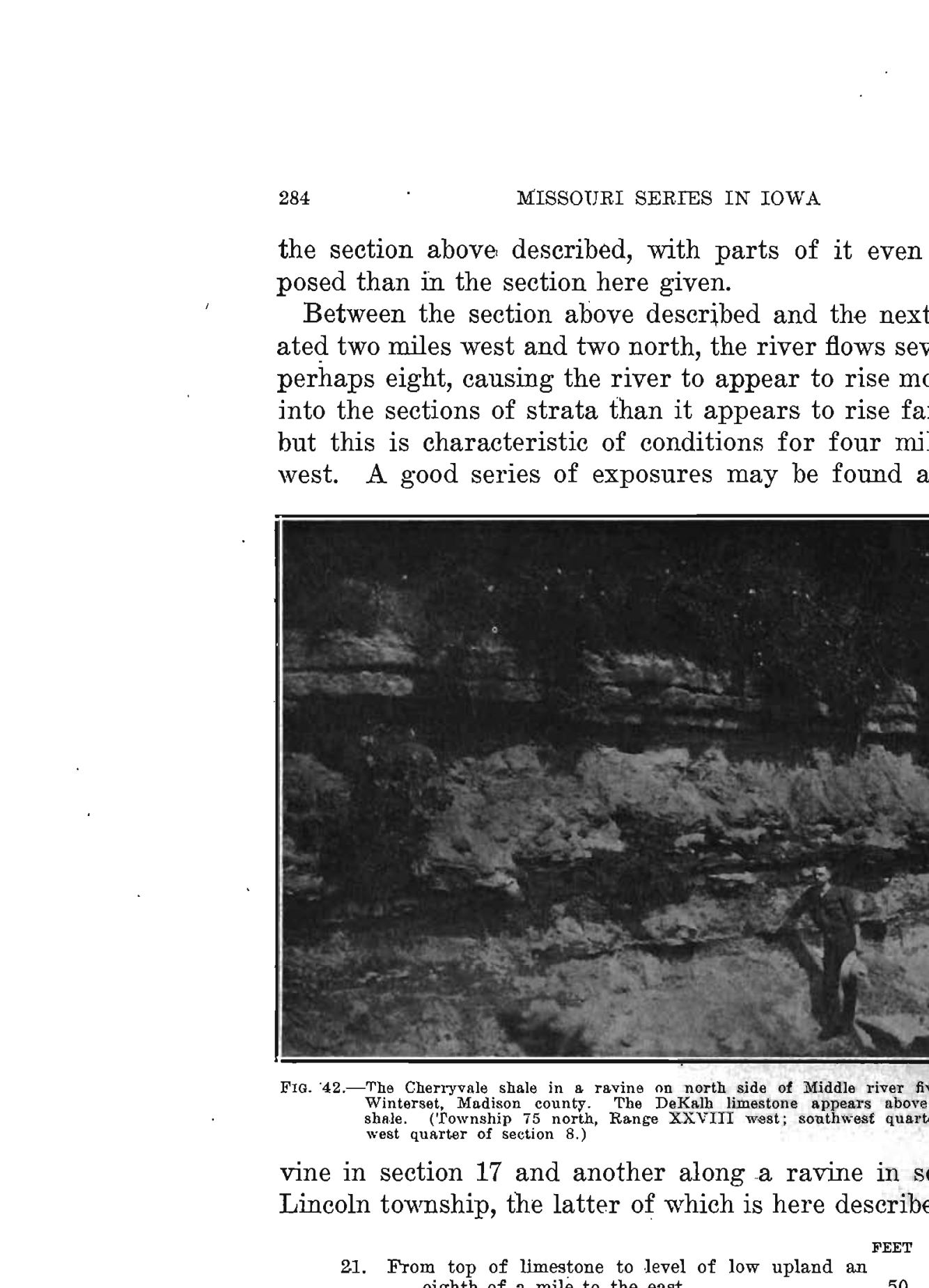

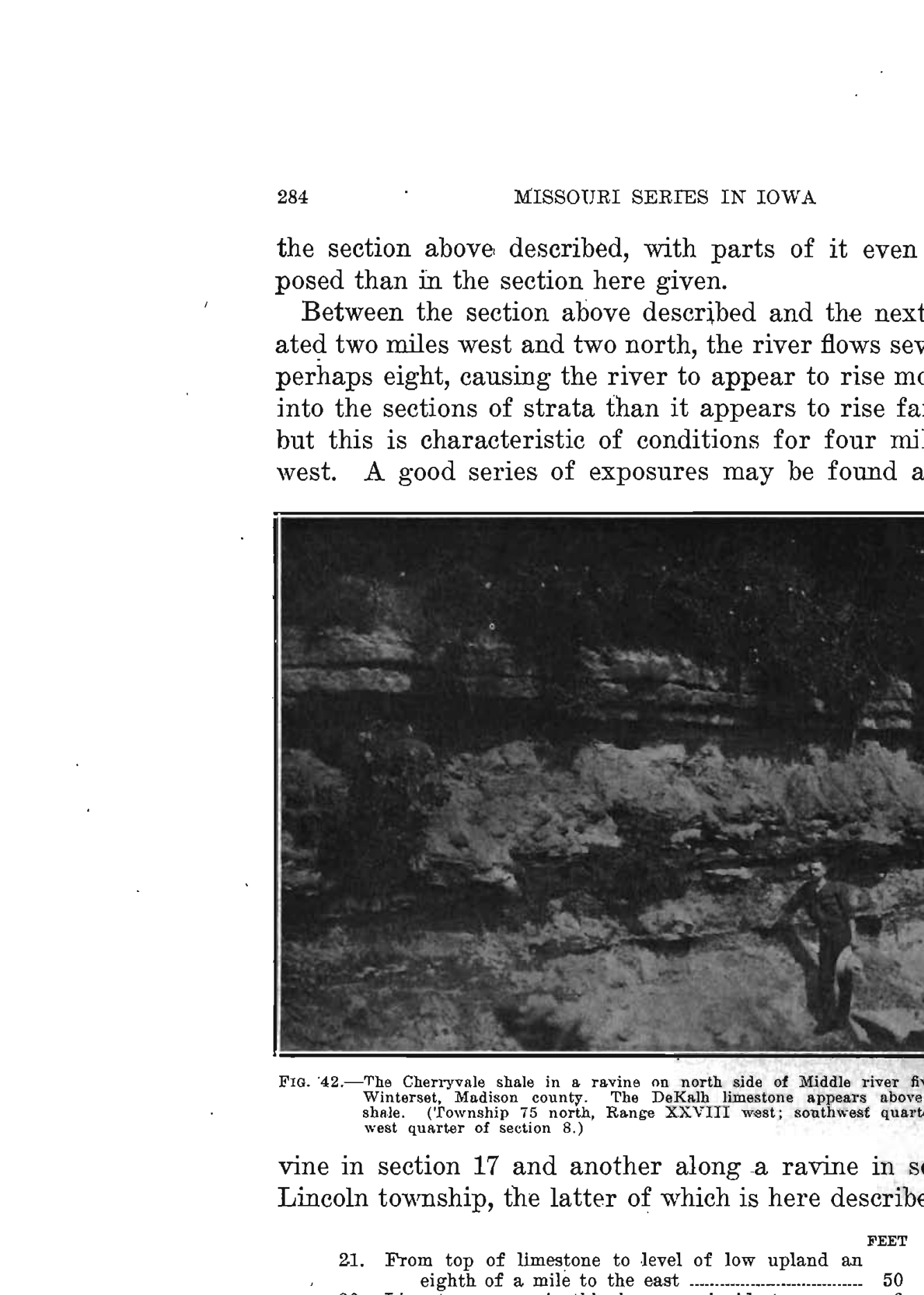

FEET INCHES

20. Limestone, gray, in thin layers; crinoid stems ....... 6 (De Kalb limestone, thickness, 6 feet.)

19. Shale, gray, argillaceous

2

18. Limestone, gray

17. Shale, gтаy, argillaceous

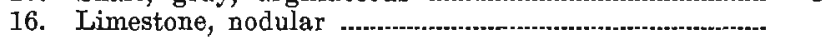

15. Shale, black

14. Limestone, black, in one stratum; Orthotetes (Derbya) crassus, Productus cora, $P$. nebrascensis...

13. Shale, blue above, gray below; one foot below the

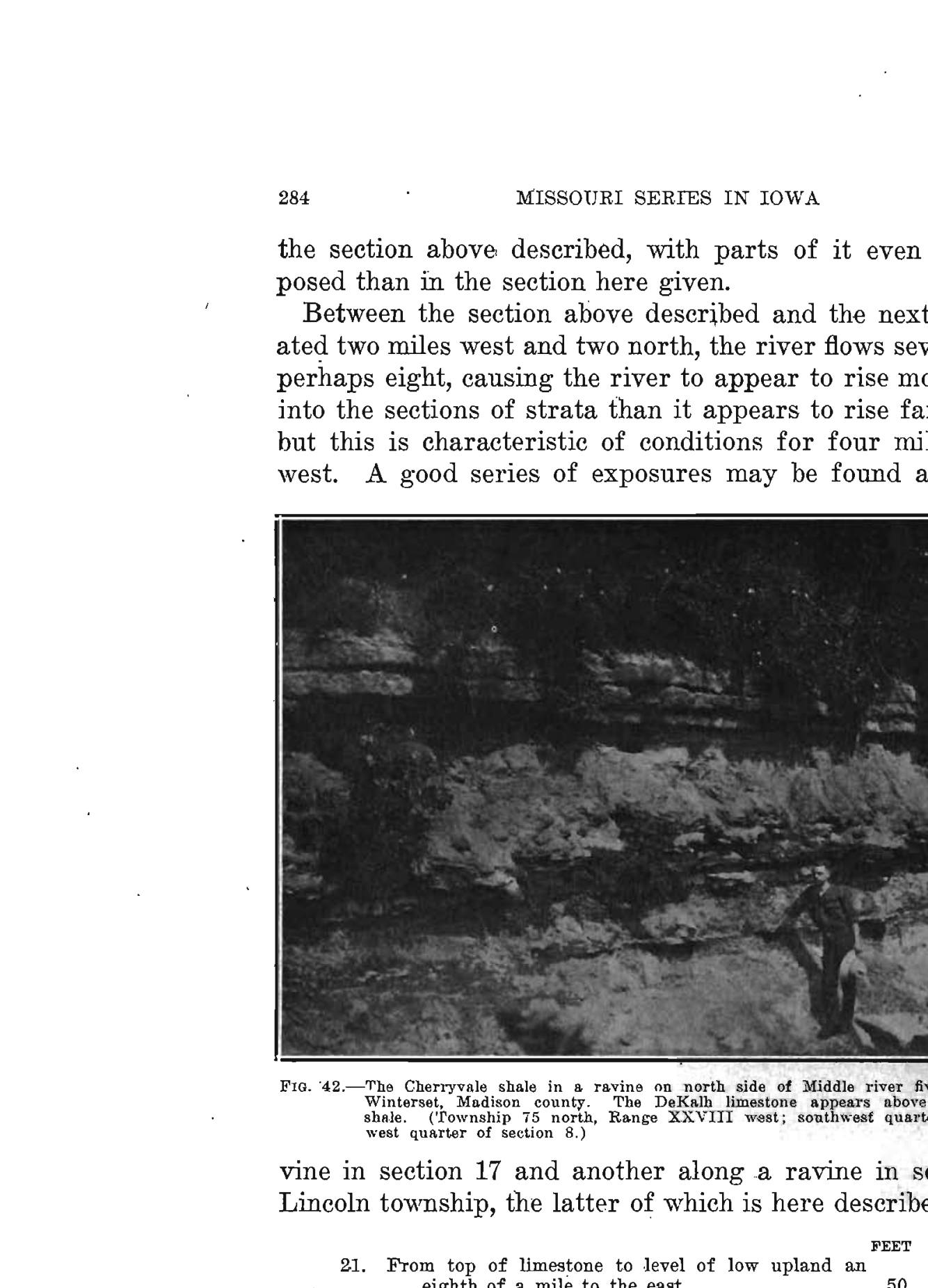

NCHES

S

.




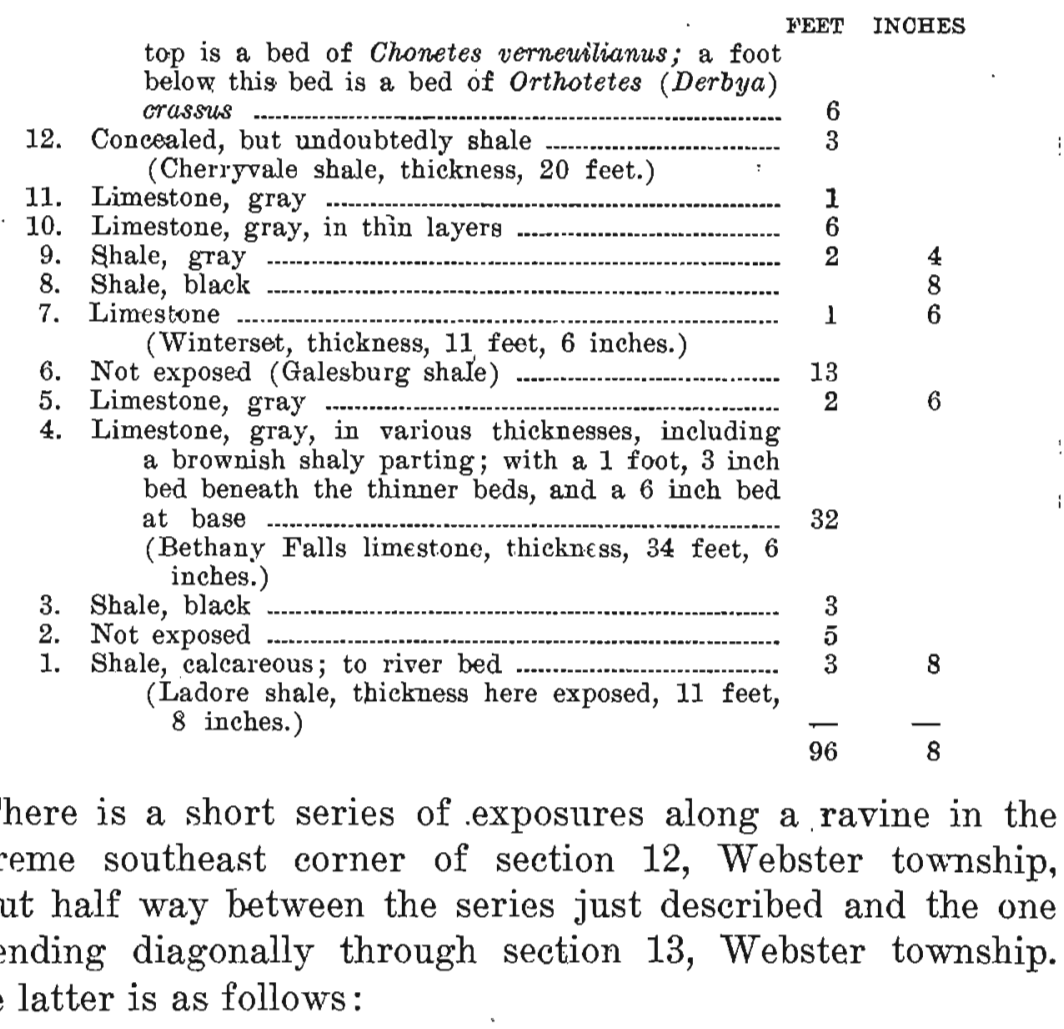

FEET INCHES

35. Limestone, gray, slight exposure by roadside near the northeast corner of section 23,67 feet above river

34. Not exposed

33. Limestone, gray, slight exposure in east-west road, near northwest corner of section 24 , and west in ravine

32. Not exposed

31. Limestone, weathered and broken

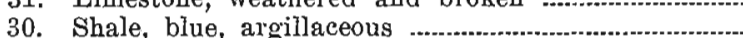

29. Limestone, yelíow

28. Shale, yellow

27. Limestone, gray, with a two inch shaly parting;

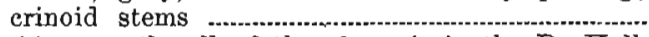
(Apparently all of the above is in the De Kalb limestone, 18 feet.)

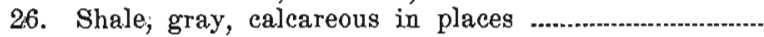

25. Shale, carbonaceous

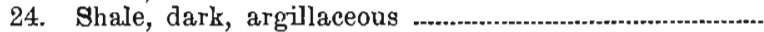

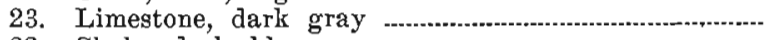

22. Shale, dark blue ................................... ductus nebrascensis, $P$. cora, very fossiliferous.-

20. Shale, gray, with diagonal eross seams of shale; 


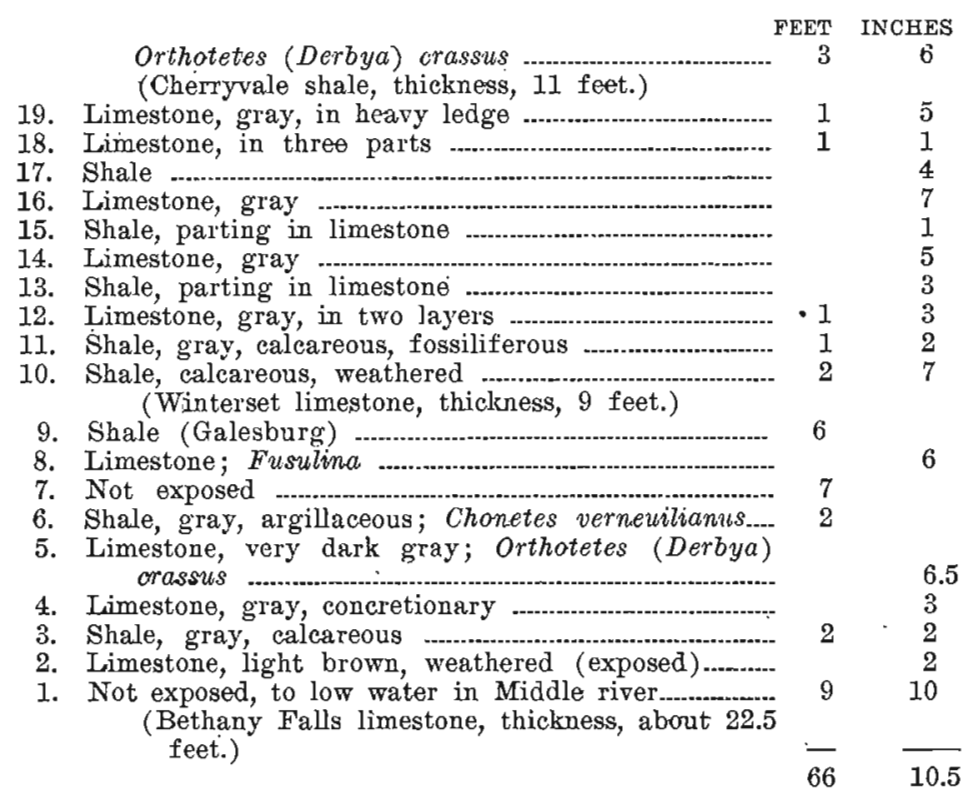

In the northeast quarter of the southeast quarter of section 14, Webster township, on both sides of the river, near the wooden bridge, the top of exposures of Winterset limestone appear twenty and one-half feet above low water in the river, . and a portion of the Bethany. Falls limestone is to be seen close to the river. The section here is as follows:

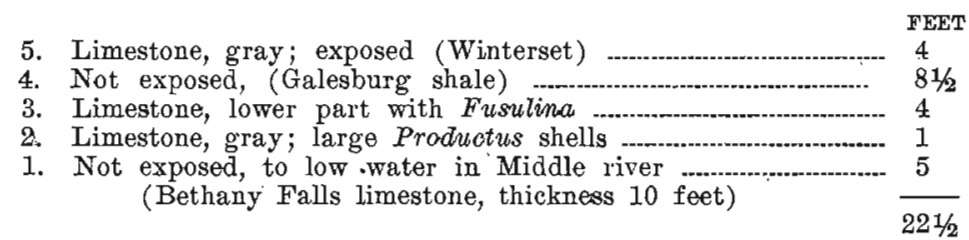

The Winterset limestone disappears beneath the river bed about a mile above this bridge. Ten or twelve feet of De Kalb limestone is to be found up Welly's branch (southwesst quarter of the southeast quarter of section 14) about twenty feet above the Winterset limestone. The De Kalb limestone also appears in the roadway west in the center of section 14, and in a small ravine in the southwest quarter of the southwest quarter of section 14, where the series of exposures gives the following, including a nearly perfect section of the Cherryvale shale: 
10. Limestone, gray, in various thicknesses from two inches up to ten inches; light colored chert; very fossiliferous; crinoid stems, Composita subtilita (De Kalb limestone)

FEET INCHES

9. Shale, gray, argillaceous

8. Limestone, light blue; crinoid stems, Pelecypods-..

7. Not exposed

6. Shale, blaćk

5. Limestone, blue; Productus prattenianus ................

4. Shale, gray, argillaceous; Orthotetes (Derbya) crassus zone

3. Shale, gray, argillaceous …............................................ (Cherryvale shale, thicknēss, 111/2 feet.)

2. Limestone (top of Winterset), shaly

1. Not exposed, to low water in Middle river

2 1

In the northwest quarter of the northwest quarter of this same section ten feet of De Kalb limestone appears up a ravine, the base of the limestone being thirty-nine feet above low water in the river. In section 10 (southeast quarter of the southwest quarter) the base of this limestone by the roadside and in a field is nine feet above the river. In section 15 to the south (southeast quarter of the northwest quarter) the base of this limestone is three and one-half feet above the river at a place where the series of exposures gives the following:

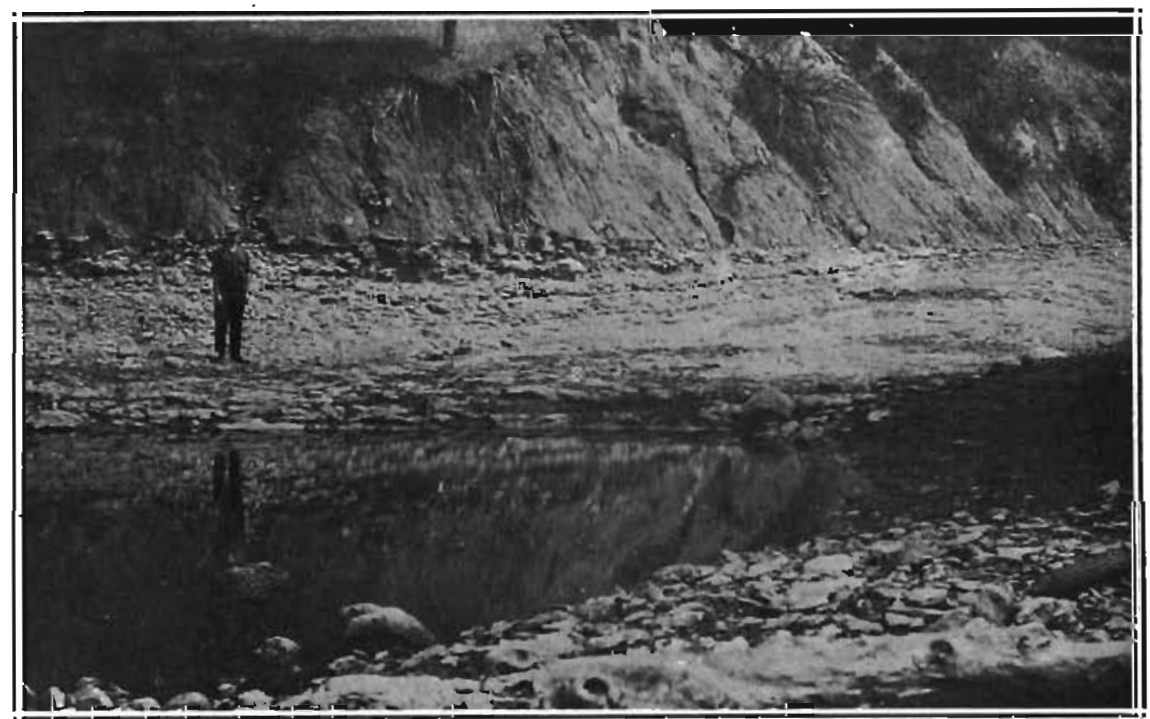

Fra. 43.-All that is left of the DeKalb limestone in the ravine northwest of Osceola. (Township 72 north, Range XXVI west, southeast quarter of the southeast quarter of section 11.) 


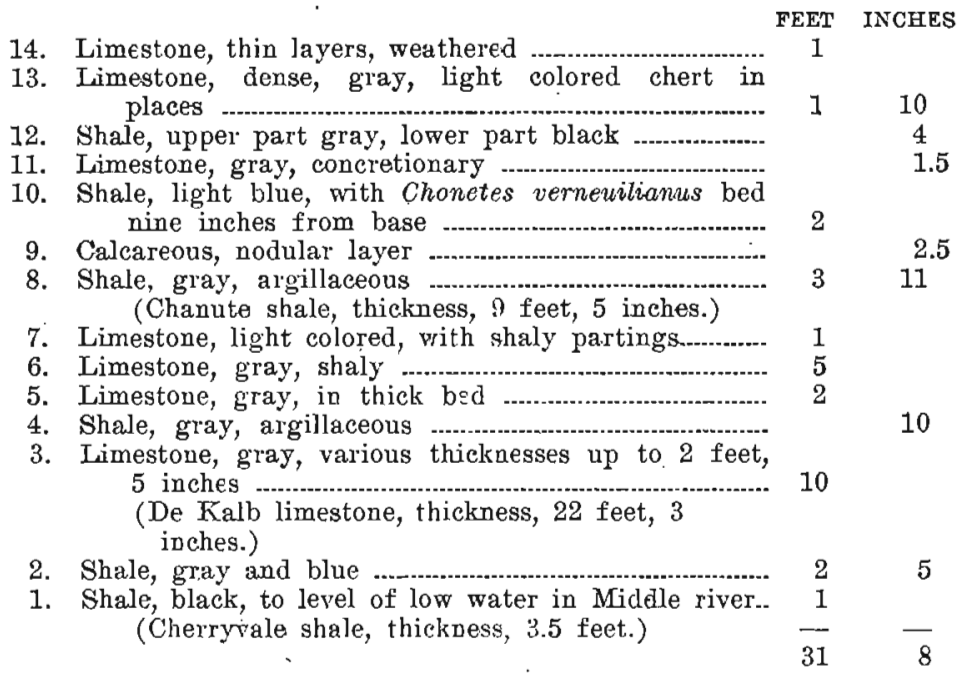

In section 9 (southeast quarter of the southeast quarter) the base of the De Kalb limestone is nine feet above" the river. The section here is as follows:

\begin{tabular}{|c|c|c|}
\hline & FEET & INCHE \\
\hline Limestone, gray, thin layers in upper portion, thick & 6 & \\
\hline Shale, grayish brown above, dark below ................ & 2 & 8 \\
\hline 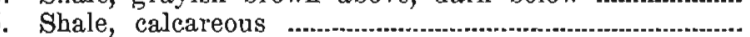 & 1 & 9 \\
\hline 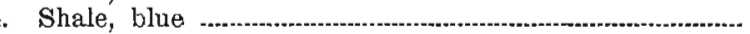 & & \\
\hline 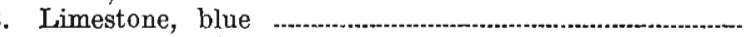 & & \\
\hline - Shale, blue; Myalina swallovi, Productus nebrasscen- & & \\
\hline $\begin{array}{l}\text { sws, } P \text {. cora, urtnotetes (Deroya) crassus.....- } \\
\text { Shale, light gray, to level of low water in Middle }\end{array}$ & 2 & \\
\hline river - a & 1 & \\
\hline (Cherryvale shale, exposed, & & \\
\hline
\end{tabular}

In section 16 (northwest quarter of the northeast quarter) the base of the De Kalb limestone is close to the level of the water in the river. In section 9 (northwest quarter of the southeast quarter) this same limestone extends in a vertical cliff from beneath the water in the river to a height of fifteen feet above the water. In section 8 (northwest quarter of the southeast quarter) the De Kalb limestone makes a low escarpment about ten feet high along the side of the flood plain for a quarter of a mile. In section 5 (southwest quarter of the southeast quarter) as far as a mile east of Webster it is this same limestone that is in the escarpment; but the limestone rises from the south since black shale appears by the river at 
the west end of the bridge in the southcentral part of section 5. It also appears in the lower part of the Brushy branch series of outcrops in sections 8 and 7 of Webster township, where the series gives the following:

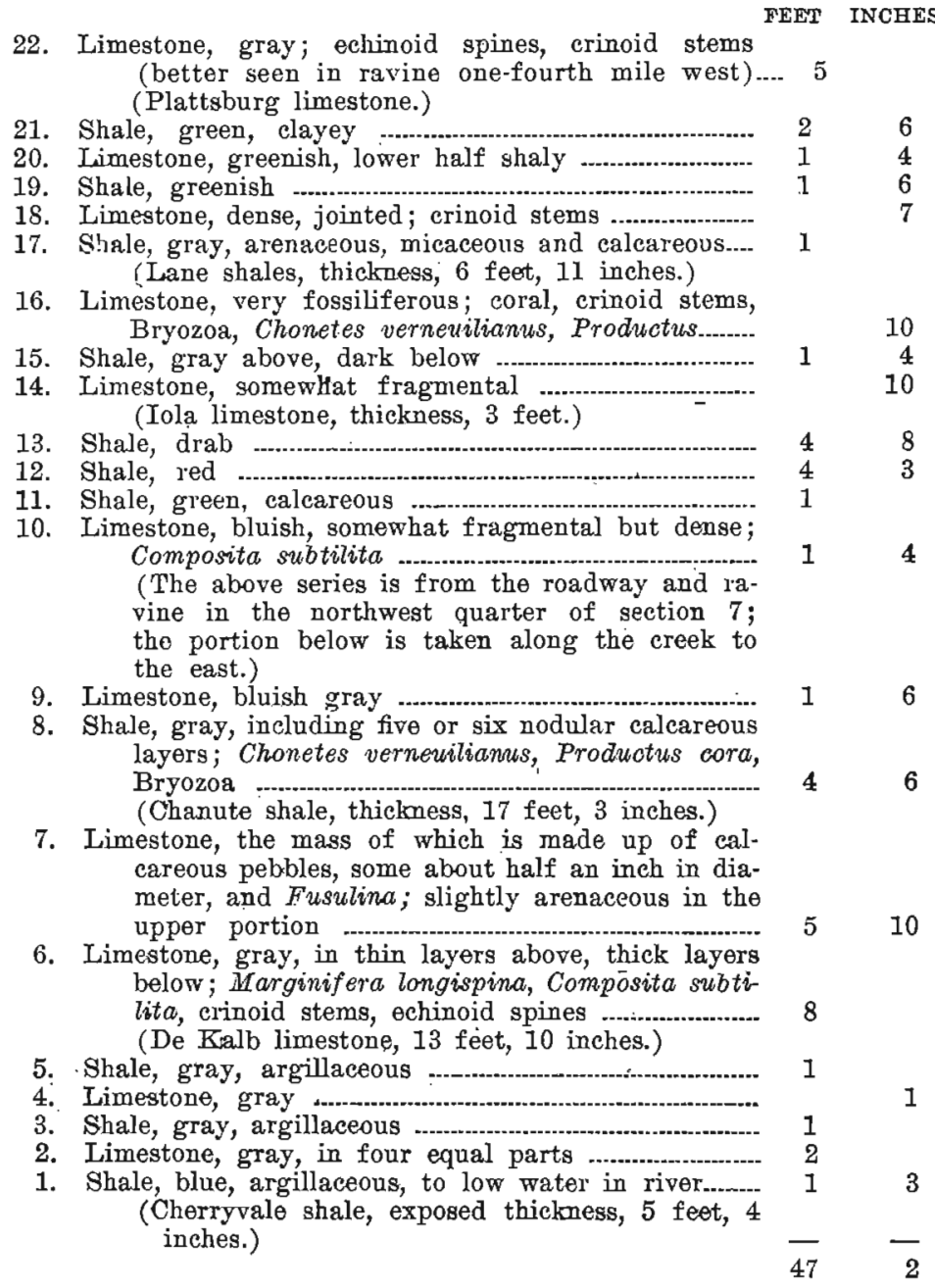

Beginning with the Iola limestone of the above series of sections and ending with the Lawrence shale the numerous limestones and shales are grouped somewhat arbitrarily and tentatively following the nomenclature of Hinds and Greene in their - description of "The Stratigraphy of the Pennsylvanian Series in Missouri." The strata vary northward to such an extent 
that with present knowledge exact parallelism is impossible. The Oread limestone, following the Lawrence shale, has definite characteristics that can be used to correlate it with strata in Cass and Montgomery, counties and with those (Plattsmouth) at the mouth of Platte river, Nebraska. For the strata above the Lawrence shale the Nebraska nomenclature is used.

. In the next four miles above Brushy branch the strata meet the river at varied distances along extensive windings of the stream. They rise fairly uniformly to the northeast, while the river valley in its general direction cuts them diagonally from the northwest to the southeast.

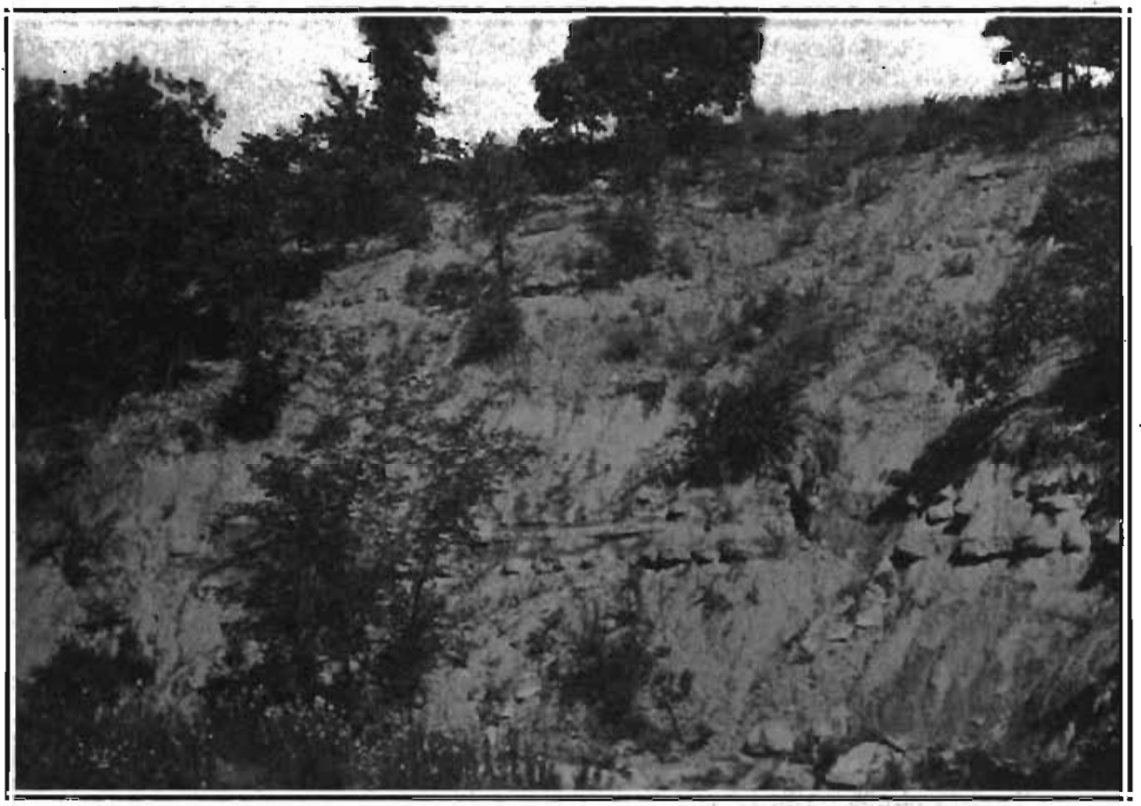

FrG. 44.- Section near the mouth of a ravine in the northeast quarter of the northeast quarter of section 1 of Grand River township, Adair county. (Township 75 north, Range $\mathrm{XXX}$ west.) The man in the picture is standing at the level of the Iola limestone. The section is described in the text.

A mile to the north of Brushy branch in section 6 of Webster township (southeast quarter of the northwest quarter) the peculiar limestone made up of small calcareous pebbles about one-half inch in diameter and of Fusulinas (the upper part of the De Kalb limestone) is about twenty feet above the water in the river. In section 1 of Grand river township, 
Adair county (northeast quarter of the northeast quarter) the same peculiar limestone is judged to be about five feet below the lowest stratum exposed in the ravine. (See figure 44.) The entire series of strata is as follows:

\begin{tabular}{|c|c|c|c|}
\hline 16. & Fragments of limestone .... & $\begin{array}{c}\text { FEET } \\
2\end{array}$ & INCHE \\
\hline & $\begin{array}{l}\text { Limestone, dense, gray } \\
\text { (Plattsburg limestone, thickmess, } 3 \text { feet, } 3 \\
\text { inches.) }\end{array}$ & 1 & 3 \\
\hline 14. & 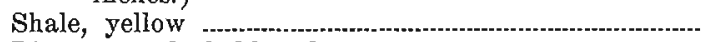 & 1 & 6 \\
\hline 3. & Limestone, dark blue, brown at top & 1 & \\
\hline 12. & $\begin{array}{l}\text { Shale, gray, argillaceous, lowest foot reddish } \\
\text { (Lane shale, thickness, } 9 \text { feet.) }\end{array}$ & 6 & 6 \\
\hline 11. & Limestone, concretionary & 1 & 3 \\
\hline 10. & $\begin{array}{l}\text { Shale, greenish gray ......................................... } \\
\text { (Iola limestone, thickness, } 3 \text { feet, }\end{array}$ & 2 & 8 \\
\hline 9 . & Shale, red & 3 & 6 \\
\hline 8. & Shale, gray, argillaceous, without fossils .................... & 16 & 5 \\
\hline 7. & Limestone, weathered & & 4 \\
\hline 6. & Shale, dark gray & & 7 \\
\hline 5. & 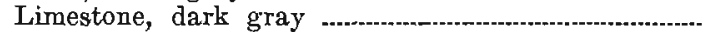 & & 6 \\
\hline 4. & 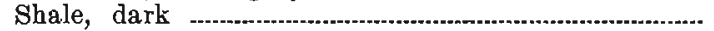 & 1 & 4 \\
\hline 3. & 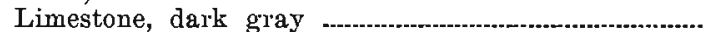 & & 10 \\
\hline 2. & Shale, gray & 9 & 5 \\
\hline 1. & $\begin{array}{l}\text { Not exposed, to low water in Middle river } \\
\text { (Chanute shale, thickness, } 41 \text { feet, } 11 \text { inches.) }\end{array}$ & 9 & \\
\hline
\end{tabular}

About a mile farther up the valley in section 36 of Harrison township, Adair county (southeast quarter of the southwest quarter) a ravine side reveals the following:

14. Limestone, weathered, and shale; Chonetes striato FEET INCHES costatus (abundant), Orthotates (Derbya) oras sus, Compositos subtilita, Productus nebrascensis, $P$. cora, coral, crinoid stems

13. Limestone, blue above, gray below; Chonetes striatocostatus, Productus nebrascensis, Fusulina oylindrica

(Plattsburg limestone, thickness, 5 feet, 6 inches.)

12. Not exposed (Lane shale)

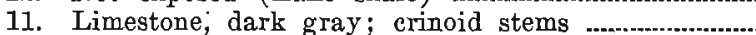

10. Shale

9. Limestone, blue, very fossiliferous, chiefly Ortho. tetes (Derbya) crassus, bryozoa. (Iola limestone, thickness, 2 feet, 1 inch.)

8. Shale, gray, argillaceous, without fossils

7. Shale, red

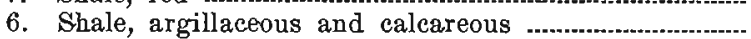

5. Shale, gray

4. Shale, red

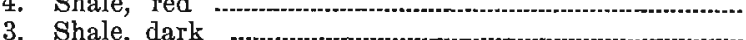

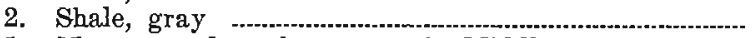

1. Not exposed, to low water in Middle river ............... (Chanute shale, thiekness, $18+$ feet.) 
The three lowest strata in the description preceding the above are here below the bed of the ravine.

An excellent series of outcrops appears by the road within another mile to the northwest, in section 35, Harrison township (northwest quarter of the northwest quarter) and may be described as follows:

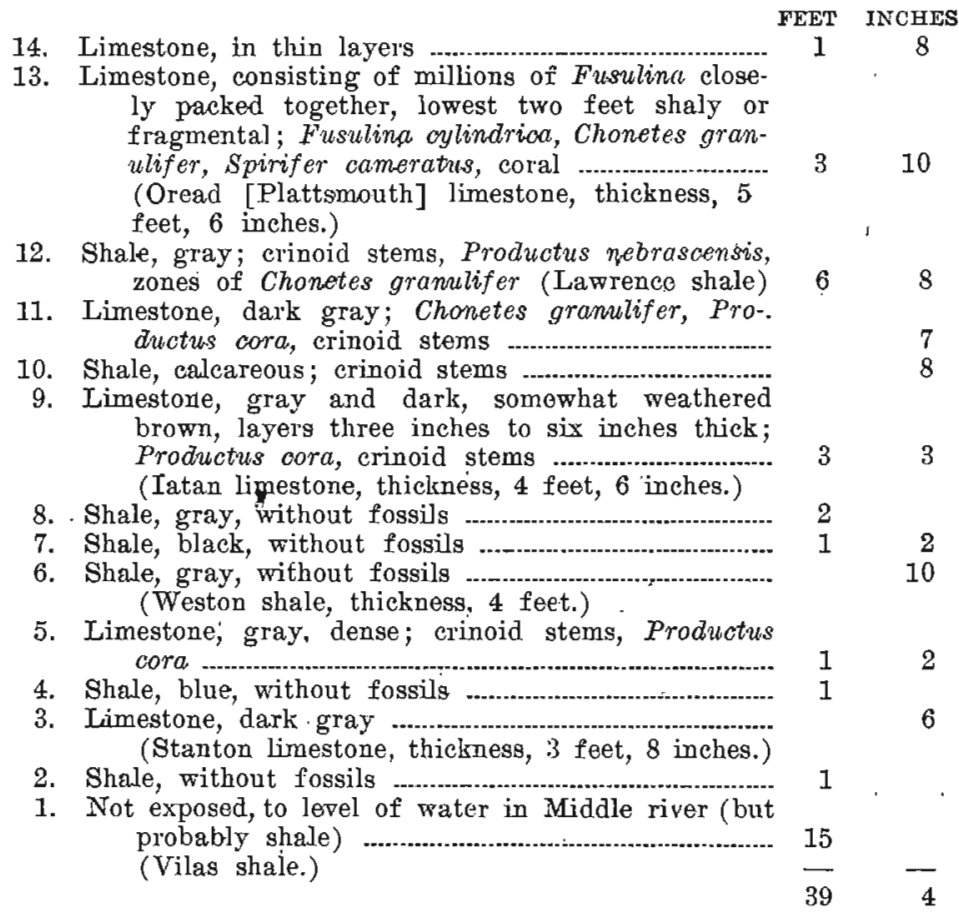

The lowest limestone (Stanton) above mentioned is the first limestone above the strata of the preceding section.

The next described series of outcrops is on the opposite side of a hill and about half a mile distant, along a ravine in section 27 (southeast quarter of the southeast quarter), Harrison township, Adair county. The series is described as follows:

19. Shale, beneath red residual material (geest)

FEET INCHES

18. Limestone. Lecompton (Cerlar Creek), gray, fragmental in upper part, channelled by underground solution; Fusulina, crinoid stems..

17. Shale, light colored, calcareous ings, fragmental at top, gray and arenaceous; bottom part very fossiliferous; fragments, fish tooth, bryozoa, Dielasma bovidens 
15. Shale, upper three feet and eight inches gray, calcareous, central three feet red, bottom four feet gray; without fossils

4. Limestone, Oread (Plattsmouth), fragmental; $F u$ sulina, Productus cora Spirifer cameratus, Chonetes, crinoid stems, coral

12. Limestone, Iatan, dark, shaly; Productus nebrasoensis, $P$. cora

11. Shale, gray

10. Limestone, dark; Productus nebrascensis

9. Shale, gray; Productus nebrascensis

8. Limestone, dark

7. Shale, gray

(Weston shale, thickness, 1 foot, 3.5 inches.)

6. Limestone, dark, irregular; Productus nebrascensis, Spirifer cameratus :t.

5. Shale, dark gray, argillaceous, without fossils.........

4. Limestone, bluish gray, in thin layers one inch to three inches thick; algalike markings, erinoid stems (margins rounded), Productus cora

3. Limestone, gray, dense, algalike markings, iron concretions

(Stanton limestone, thickness, 3 feet, 1 inch.)

2. Shale, Vilas, argíllaceous, gray and green, iron concretions

1. Not exposed, to level of low water in Middle river

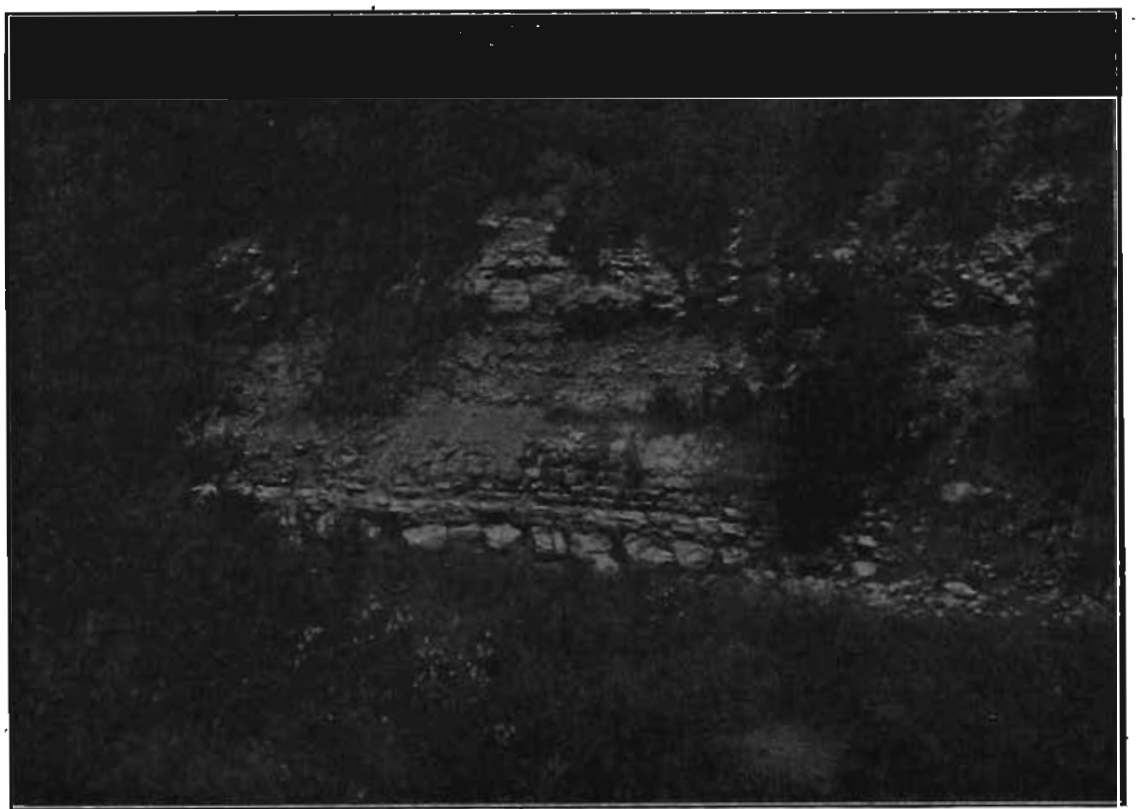

Fia. 45.- Section in a ravine in the southeast quarter of the southeast quarter of santion 27. Harrison township, Adair county. (Township 76 north, Range XXX west.) The Stanton limestone is at the base of the cliff, the Iatan limestone near the center, and the Oread limestone near the top. All of the strata appear in the hed and sides of the trench farther up the ravine to the west. The section is described in the text. 


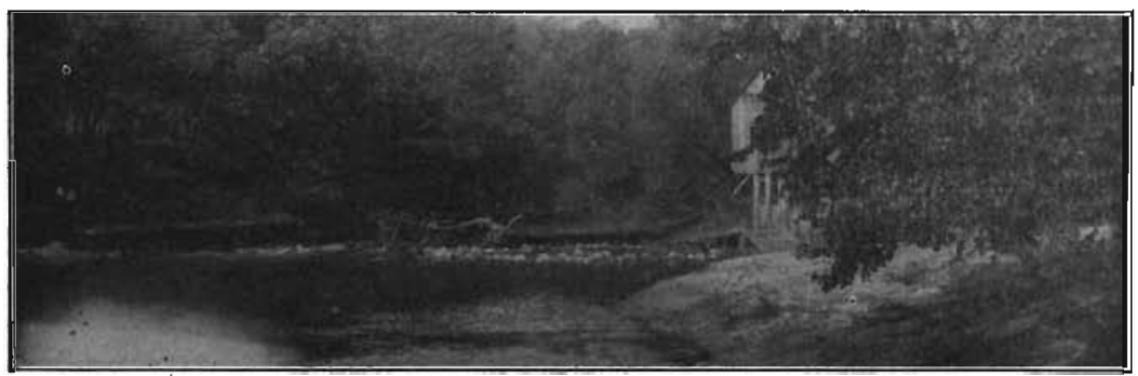

Fr' 48. "Pórt Union Mill" in half a mile upstream from the bridge at Arbor Hill. It is located in the southwiest quarter of the northeast quarter of section 20, Township 76 north, Range XXX west. The base of the Deer Croek (Forbes) limestone is in the text.

The top of the Lawrence shale appears in a ravine by the road nearly a mile north (section 27 , northeast quarter of the northeast quarter); and at the bridge (section 22, southeast quarter of the southeast quarter) the Oread limestone is four feet thick and is eight feet above the river. In section 21 (southeast quarter of the southeast quarter) the Oread apparently is below the river bed. About a foot of poor limestone is here exposed four feet above the river, with four to five feet

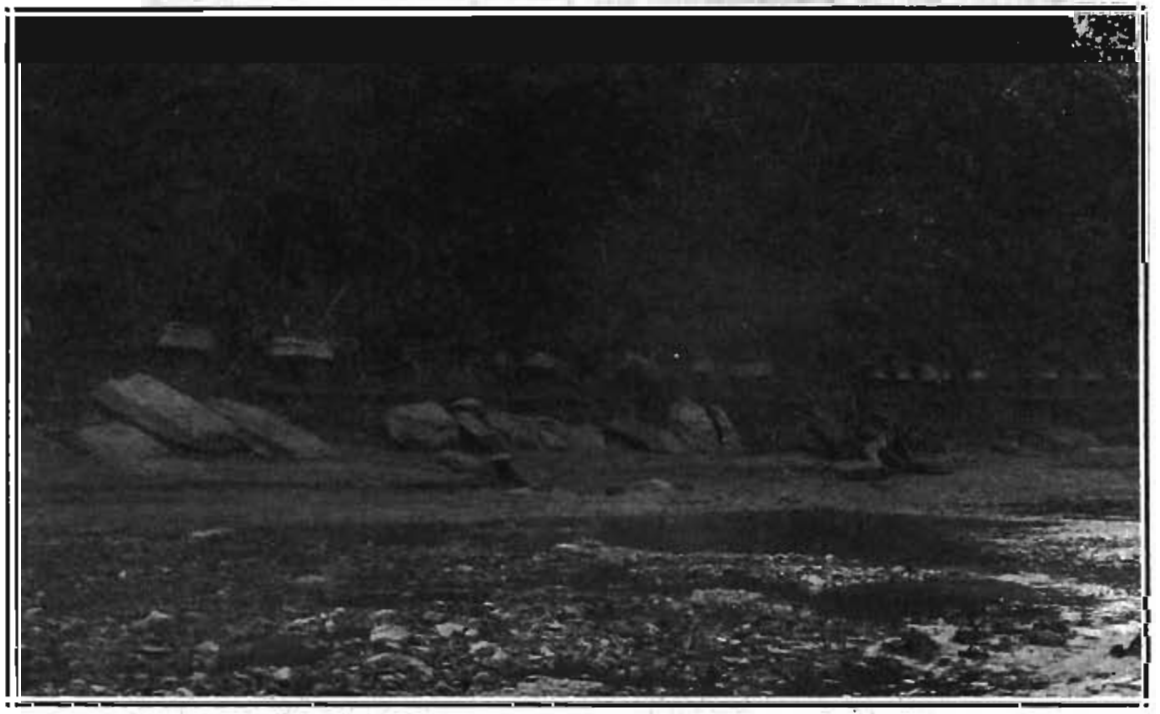

Fxg. 47.-The location is a few rods down stream from the dam' at "Port Union Mill," looking westward at beds associated with the Deer Creek (Forbes) limestone. 


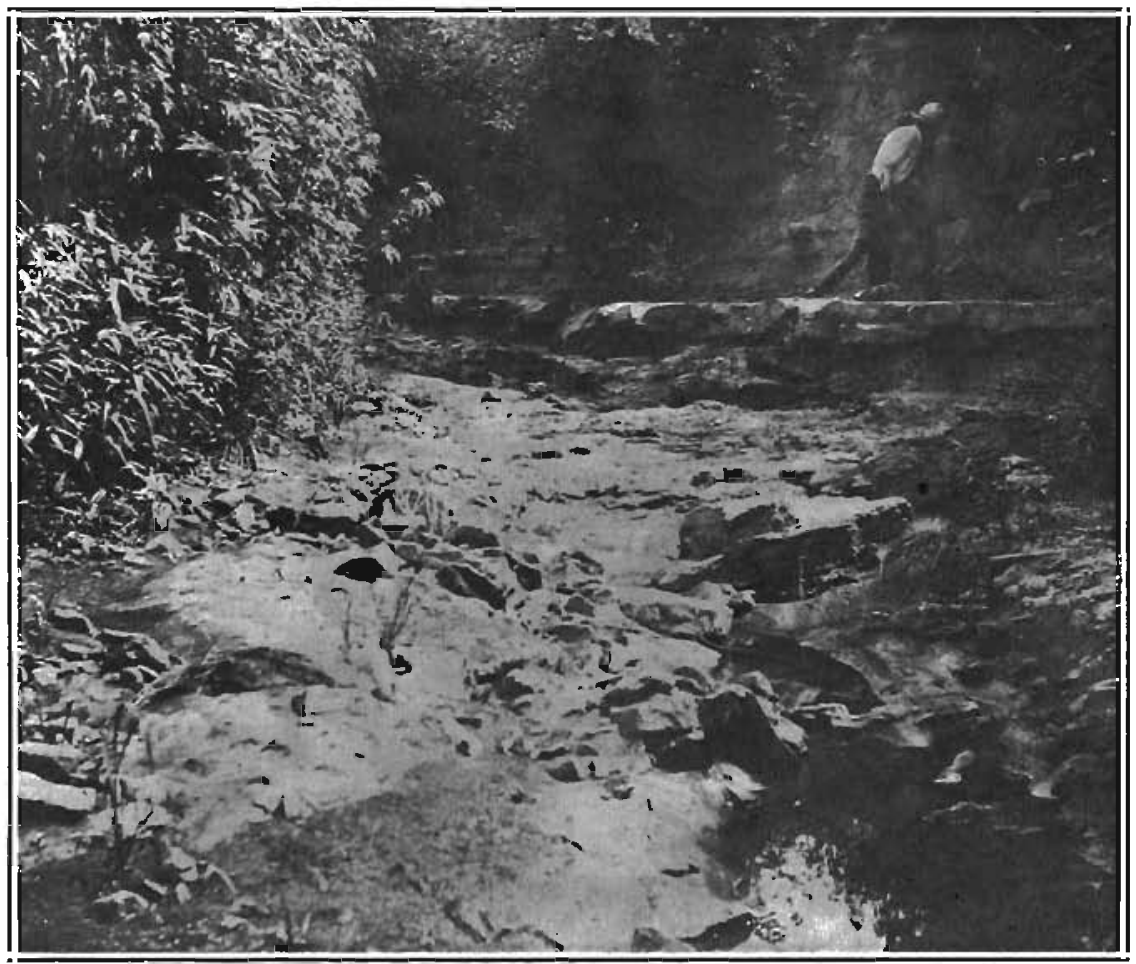

Fia. 48-The Deer Creek (Forbes) limestone found at "Port Union Mill" and near Stennett also outcrops north of Hawleyville in Page county. (Township 69 north, Range XXXVI west, northeast quarter of section 12). This outcrop was illustrated and described in the report on the "Geology of Page County." The limestone that is uppermost is the Topeka (Meadow) limestone.

of reddish and greenish shale above the limestone. In section 21 (northeast quarter of the southwest quarter) a limestone is three feet above water in the river; at Arbor Hill bridge (section 20, southeast quarter of the northeast quarter) this particular. limestone is at the level of the water under the bridge. Half a mile up stream from the bridge is the site of the "Port Union mill," at which place James E. Gow described a section as follows. (southwest quarter of the northeast quarter of section 20:

3. Limestone, light buff, varying to white or light gray Composita subtilita, Orthotetes (Derbya) crassus, Spirifer camerotus, Productus fragments, Myalina subquadrata, erinoid stems, Fenestella, Rhombopora lepidodendroides

2. Shale, blue-black, homogeneous; Nucula (ventricosa?) 
The lower limestone above mentioned is at the surface of the water below the dam, and is above the limestone at the bridge.

'The distinctive layers of the Deer Creek limestone with $F u$ sulinas and dark chert outerop by the river side a mile northwest of Port Union mill (the northeast quarter of the southeast quarte of section 18, Harrison township). Close to the center of the next section west (13 of Grove township) fragments of a limestone appear that, traced northward along the river, attains a greatest thickness of outcrop a mile north (section 12) where it was formerly quarried. It is the base of this same limestone that outerops by the bridge in the southeast quarter of section 21, Jefferson township, and lies just below the limestone that is at the level of the river in the southwest quarter of section 16, where it is fifty feet below Stuart, or at a level of 1,157 feet above sea level. In section 21 of Jefferson township the writer found Marginifera muricate (the index fossil of the Des Moines series), Ambocelia planoconvexa, Composita subtilita, Hustedia mormoni, Spirifer cameratus, also Fusulina, Bryozoa and coral. Gow's description is as follows:

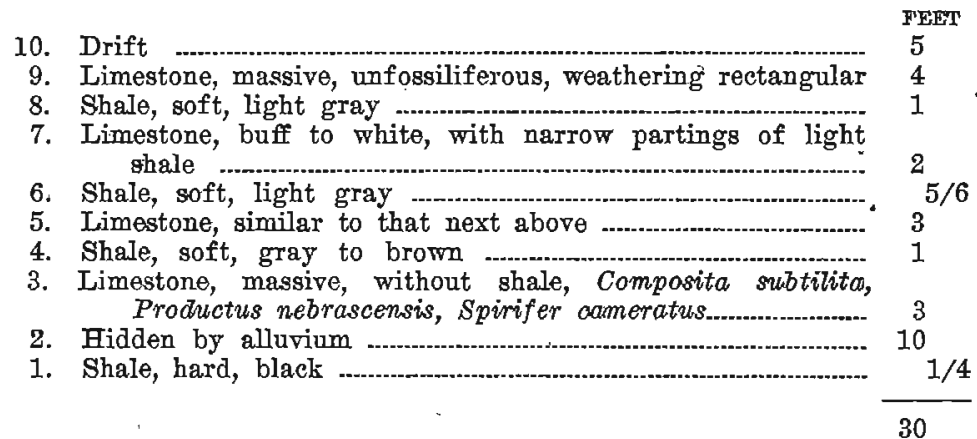

This limestone is the upper limestone member (Pawnee) of the Henrietta division of the Des Moines series. ${ }^{70}$ The river

69Geology of Adair county; Iowa Geol. Survey, Vol. XXVII, p. 288.

70The relation of the beds is discussed further in the Bulletin of the Geological Society of America, Vol. 23, p. 153, 1922 . 
Iow: Geotogical Survit

P.ATE XXV

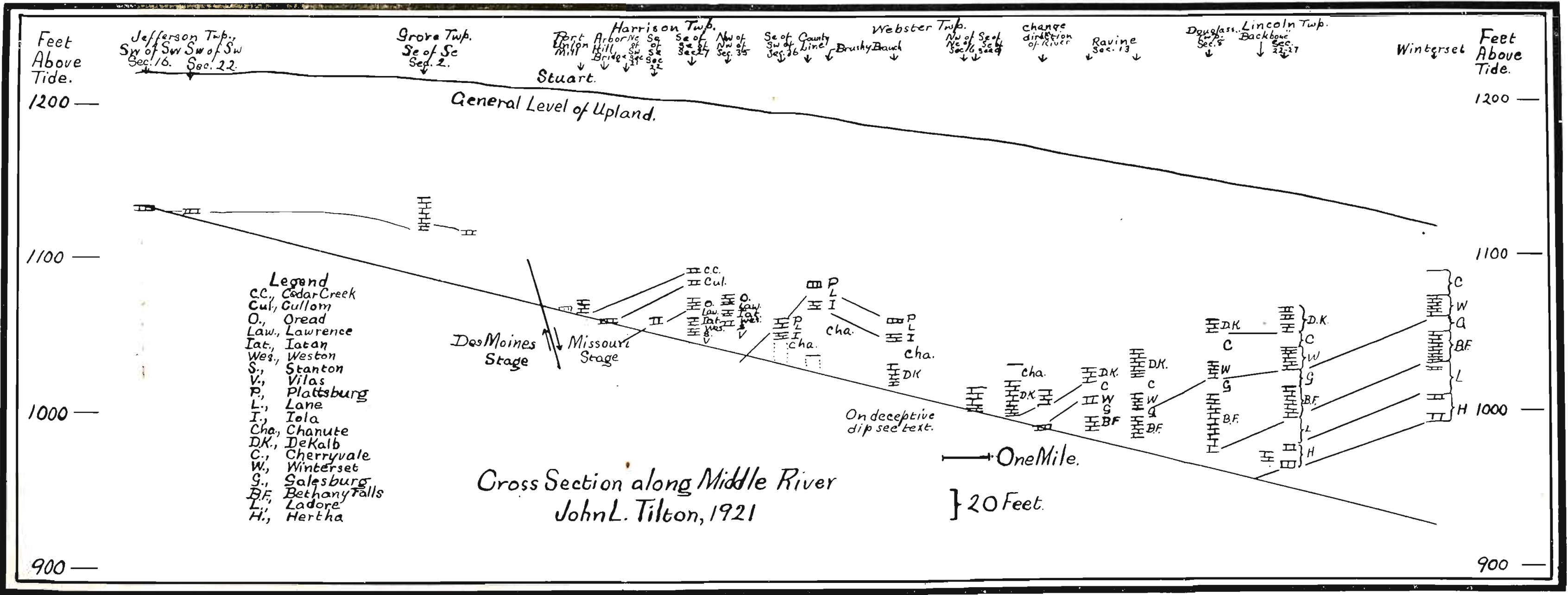


crosses the Thurman-Wilson fault in the center of section 18, Harrison township, a mile up the valley from Point Union mill. These various sections arranged in order with reference to the river bed give the accompanying cross section along Middle river.

\section{The Structure of Southwestern Iowa.}

The area as a whole is the northern limb of a syncline (strata concave upward) whose axis extends northwest-southeast through northwestern Missouri and northward into Iowa. The other limb of the syncline slopes upward toward the Ozark Mountains. $^{71}$ In southwestern Iowa the general dip to the southwest is so slight that it is often scarcely noticeable in short distances. The average obtained from Winterset to Clarinda is 8.6 feet to the mile or $4 \frac{1}{2}$ minutes.

Diagonally through the entire area runs a normal fault, known as the Thurman-Wilson fault, extending northeastward from the bluffs along Missouri river near Thurman, where the displacement is 300 feet, past Briscoe, where the displacement is 284.5 feet, to the northwest of Earlham. At present there is no information as to its presence from this point eastward. The fault has not been found in Nebraska.

Keyes $^{72}$ describes the Cap-au-gres fault seen on Mississippi river as extending northwest toward Leon, and possibly farther; but if it is present at all in Iowa it has not yet been re-

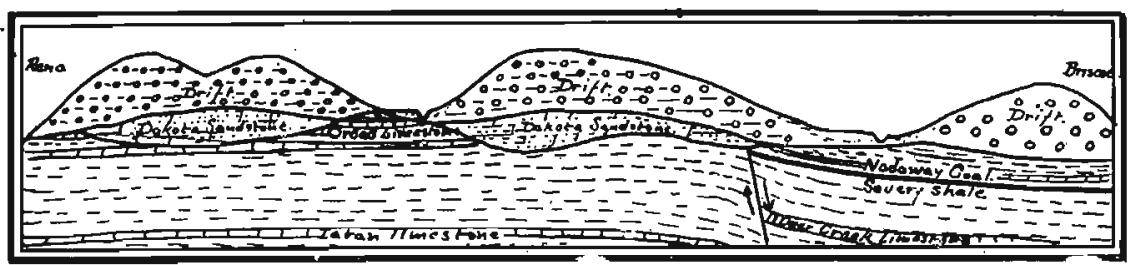

FIG. 49.-Diagram of conditions across the fault plane; from Reno, Edna township, Cass county, southeast to Briscoe.

cognized. He also represents a Pocahontas and a Fort Dodge fault, running southwest-northeast, parallel to the ThurmanWilson fault; but the positions he designates lie beyond the area here considered ${ }^{72^{\mathrm{a}}}$.

\footnotetext{
71 See Hinds and Greene. The Stratigraphy of the Pennsylvanian' Series in Missouri: Missouri Bur. Mines, Bull. XIII, p. 202, plate XXIII.

72C. R. Keyes, Controlling Fault Systems of Iowa: Proc. Iowa Acad. Sci., Vol. XXIII, 105.

7-2n. A. Wilder discusses the structure of the Fort Dodge region on pages 173 to 177 of Volume XXVIII, Iowa Geological Survey, and James H. Loes has a paper on that same region, on pages 113 to 120 of Volume XXIX of the Proceedings of the Iowa Academy of Science.
} 
Near the Thurman-Wilson fault the dip is very irregular. Parallel to the fault and on the west side of it lies the crest of a slight anticline (strata convex upward), distinctly seen in Montgomery and Cass counties, and also in Dallas county where Leonard described it years ago as the Redfield anticline ${ }^{73}$ without noting its relation to a fault. Close to the south side of the fault (the downthrow side) the strata, rising in general toward the northeast, curve off toward the west. This is particularly noticeable in the limestone members of the Kansas City stage near Earlham; but farther to the southwest this characteristic is not so noticeable because the strata are at a lower level with reference to the drift-they are exposed deeper in the valleys.

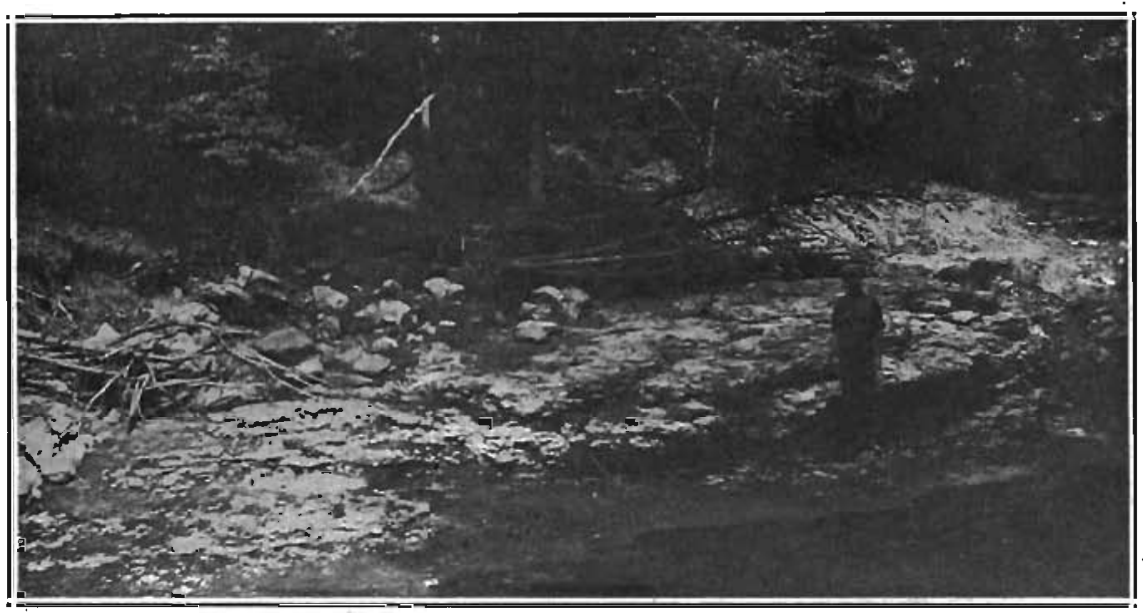

Fro. 50.- The uneven surface of the Winterset limestone in a ravine northwest of Osceola, Clarke county. (Township 72 north, Range XXVI west, southeast quarter of the southeast quarter of section 11.)

There are conditions that indicate an overlap with disconformity, and in one portion of the area an unconformity. In the northwest part of the area there is no evidence of the presence of the Kansas City stage, and it is the Lansing stage that there extends farthest toward the north. In the central and western part of the area the fossils and general character of the Oread limestone suggest that that limestone was laid down during the time of greatest advance, when marine conditions were most farorable to life forms, but in the northeast and northwest

73A. G. Leonard, Geology of Dallas County: Iowa Geol. Survey, Vol. VIII, p. 91. 


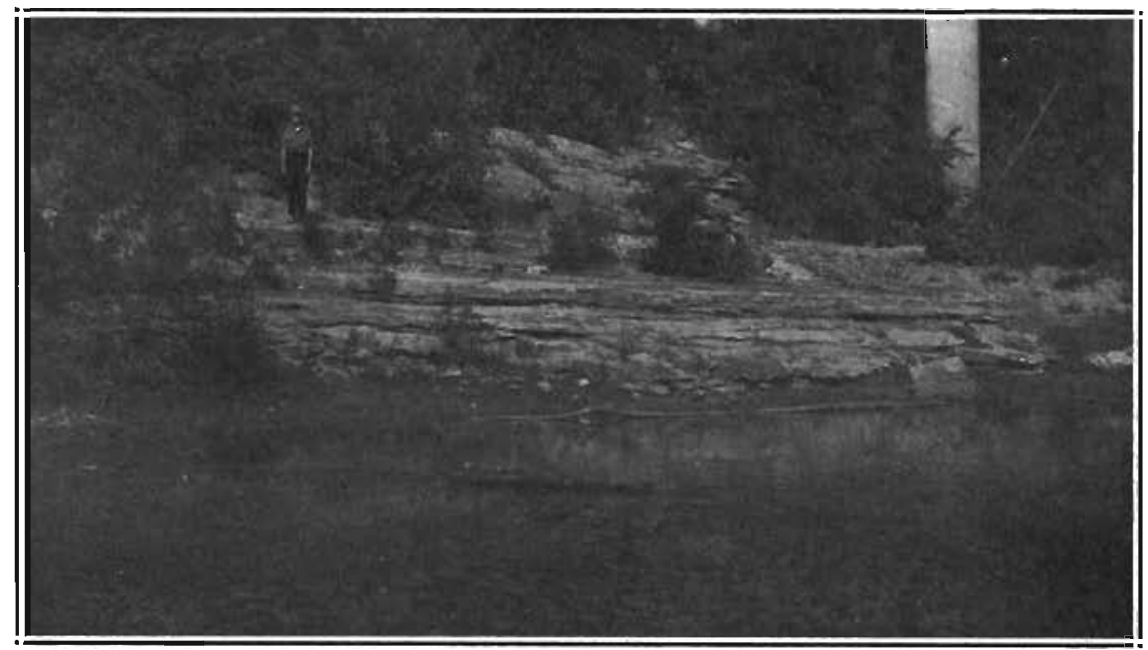

FIa. 51.-The surface of the Winterset at the bridge three and one-half miles west of Decatur City, Decatur county, where a slight unconformity is noted. The Winterset limestone is beneath the feot of the one in the picture. The limestone above this leve is DeKalb limestone that has fallen down.

portions of the area the Oread is now absent. At the bridge over Grand river three miles west of Decatur City, in the eastern part of the area, there is a difference in dip between the Winterset limestone below and the De Kalb above. Here the distinctive beds of the Cherryvale shale, which are so noticeable south of Westerville and elsewhere, are concealed if they are present at all. Two miles west of Osceola and a little north the fragmental top of the Winterset limestone is eroded; and at Winterset there is at this horizon a yellowish apparently weathered stratum. These facts put together seem to indicate a local uplift near Decatur City followed by depression between the time when the Winterset. was laid down and the time when the lower part of the De Kalb was laid down, which subsidence, either with or without slight warping, led to extensive overlap in the northwestern part of the area.

The general dip to the southwest is varied by a few gentle folds whose axes appear to run southeast-northwest, though there is much irregularity, especially near the fault. The exact number and the position of these folds it is difficult to determine from the few exposures of bed rock. One gentle anticline is the one previously noted three miles west of De- 
catur City, which apparently is a continuation of the one observed five miles north of Davis City. This possibly connects with the one seen along Middle river in sections 14 and 15, Webster township, Madison county. Another passes through Braddyville, Page county, lying a little to the north of the direction of an anticline which Hinds and Greene have located in Missouri as extending through Chariton, Livingston, Davies, Gentry and Nodaway counties, but apparently dying out before reaching Hamburg. Another syncline which is reported in Missouri would come midway between. Decatur City and Braddyville, but it is not mapped as reaching Iowa. An extension of this line would pass near Brooks, Adams county. East of Brooks the dip is as usual in Iowa, to the southwest, with no reversal of dip noted southwest of Brooks. Between Braddyville and Hawleyville there is a syncline, and another slight one is present between Mrckissick grove and Nebraska City. There are also slight variations in dip that are noticeable as the strata are followed along the rivers.

DIP AND STRIKE

With the exception of the record in Dallas county and two measurements referred to in the footnote all records of measurements of $\mathrm{dip}^{74}$ and strike have been obtained by the writer, using a Brunton hand transit to measure the dip or to determine the location of a horizontal line from which to measure. At some places the direction of strike (the direction in which the strata cut a horizontal plane) was not obtainable, but a component of the dip was seen in some particular direction. On the accompanying outline map such determinations are represented by dotted arrows. A few statements of direction of dip may be found in some of the county reports without record of the amount or exact direction of the dip. Of such a character is the statement of the dip at Braddyville.

74Smith's statement of a steep dip to the north for outcrops near Stennett is a mistake. The Carboniferous Section of Southwestern Iowa: Iowa Geol. Survey, Vol. XIX, p. 686. 
TABLE OF DIP AND STRIKE

\begin{tabular}{|c|c|c|c|c|c|c|c|c|}
\hline CoUnTX & $\begin{array}{c}\text { TwP. } \\
\text { N. }\end{array}$ & RanaE W. & SECTION & Place & STRIKE & DiP & $\begin{array}{l}\text { DIRECTION } \\
\text { OF FACE OF } \\
\text { OUTCROP }\end{array}$ & $\begin{array}{c}\text { DIP IN } \\
\text { DIRECTION } \\
\text { OF OUTCROP }\end{array}$ \\
\hline$\overline{\text { Guthrie ....... }}$ & 79 & $\overline{X X \bar{X}}$ & $30-31$ & Belle Valley mill & $\mathrm{N45^{ \circ } \mathrm { E }}$ & $45^{\circ} \mathrm{Se}$ & & \\
\hline \multirow[t]{5}{*}{$\overline{\text { Madison ...... }}$} & 74 & XXVII & 10 & Per'u quarry & $\mathrm{N} 70^{\circ} \mathrm{W}$ & $1^{\circ} 30^{\prime} \mathrm{Sw}$. & & \\
\hline & 75 & $\mathrm{XXIX}$ & Se. of Nw. of 15 & & & & Downstream E & $23^{1 *}$ \\
\hline & & & N. half of Nw. qr. 14 & & & & $\overline{\text { Upstream } \bar{W}}$ & $2 \% 4^{\prime *}$ \\
\hline & $7 \overline{6}$ & $\overline{\mathrm{XXVII}}$ & $\overline{\mathrm{Ne}}$ of the Nw. qr. of 6 & & & & $\mathrm{~N} 34^{\circ} \mathrm{W}$ & $2^{\circ} 50^{\prime}$ \\
\hline & $7 \overline{5}$ & XXVIII & W. center of 22 & & & & $\mathrm{~N} 6^{\circ} 30^{\prime} \mathrm{W}$ & $1^{\circ} 30^{\prime}$ \\
\hline$\overline{A d a i r ~ . . . . . . . . . . . . . ~}$ & 76 & $\mathrm{XXXI}$ & Nw. of the $\mathrm{Nw}$. of 11 & & $\mathrm{~N} 10^{\circ} \mathrm{E}$ & $1^{\circ} 15^{\prime} \mathrm{W}$ & & $1^{\circ} 15^{\prime}$ \\
\hline \multirow{3}{*}{ Cass ................ } & $\overline{7} \overline{6}$ & XXXVII & Se. of the Ny. qr. of 9 & Spring creek & $\mathrm{N} 85^{\circ} \mathrm{W}$ & $3^{\circ} 45^{\prime} \mathrm{E}$ & & \\
\hline & & & Nw. of the Sw. qr. of 10 & Lewis & $\mathrm{N85^{ \circ } \mathrm { W }}$ & $3^{\circ} 45^{\prime} \mathrm{E}^{-}$ & & \\
\hline & & & Center of Ne. qr. of 1 & Turkey creek & & $0^{\circ}$ & & \\
\hline 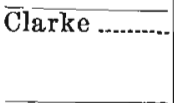 & 72 & $\overline{\mathrm{X}} \overline{\mathrm{XV}} \mathrm{I}^{-}$ & $\begin{array}{l}\text { Nw. of the Nw. of } 1 \\
\text { and } \\
\text { Ne. of the Ne. of } 11\end{array}$ & & $\mathrm{~N} 77^{\circ} \mathrm{W}$ & $\begin{array}{c}\text { Av. of sever } \\
4^{\circ} 6^{\prime} \mathrm{W}\end{array}$ & & \\
\hline \multirow[t]{3}{*}{ Union.............. } & 71 & XXVIII & Ne. of the Ne. of 14 & & $\mathrm{~N} 80^{\circ} \mathrm{W}$ & $3^{\circ} 15^{\prime} \mathrm{W}$ & & \\
\hline & & & Ne. of the Sw. of. 36 & & $\mathrm{~N} 85^{\circ} \mathrm{W}$ & $1^{\circ} 45^{\prime} \mathrm{W}$ & & \\
\hline & $\overline{72}$ & XXVIII & Sw. of the Sw. of 28 & & & & $\mathrm{~N} 70^{\circ} \mathrm{W}$ & $5^{\circ}$ \\
\hline \multirow[t]{4}{*}{ 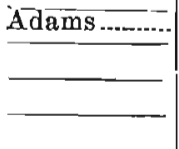 } & 73 & $\mathrm{XXXV}$ & Se. of the Nw. of 3 & & $\mathrm{~N} 90^{\circ} \mathrm{E}$ & $2^{\circ} 48^{\prime} \mathrm{S}$ & & \\
\hline & & & $N w$. of $N w$. of 6 & & $\overline{N 80^{\circ}} \overline{\mathrm{W}}$ & $1^{\circ} 45^{\prime}$ & & \\
\hline & 71 & XXXIV & Se. of Se. of 8 & & $\mathrm{~N} 32^{\circ} \mathrm{W}$ & $3^{\circ} 15^{\prime} \mathrm{S}$ & & \\
\hline & & & Ne. of Sw. of 3 & & & & $\mathrm{~S} 47^{\circ} \mathrm{W}$ & $2^{\circ}$ \\
\hline \multirow[t]{3}{*}{$\overline{\text { Montgomery }}$} & 72 & XXXVin & Nw. of Nw. of 16 & Riverview Park & & & $\mathrm{S} 46^{\circ} \mathrm{E}$ & $3^{\circ} 45^{\prime}$ \\
\hline & & & South center, 26 & & & & $\mathrm{~S} 20^{\circ} \mathrm{E}$ & $30^{\prime}$ \\
\hline & & & Sw. of . Sw. of 26 & & $\mathrm{~N} 0^{\circ} \mathrm{E}$ & $3^{\circ} \mathrm{E}$ & & \\
\hline$\overline{\text { Mills } \ldots . . . . . . . . . ~}$ & 73 & $\overline{\mathrm{X}} \overline{\mathrm{LI}} \overline{\mathrm{III}}$ & Sw. of Nw. of 29 & Henton & & & $\mathrm{S} 5^{\circ} \mathrm{E}$ & $2^{\circ}$ \\
\hline \multirow[t]{4}{*}{$\overline{\text { Decatur } \ldots . . . . . . . ~}$} & 70 & $\overline{X X V I}$ & Center of 28 & & & & $\mathrm{~S} 48^{\circ} \mathrm{E}$ & $1^{\circ} 10^{\prime}$ \\
\hline & -70 & $\bar{X} \times V I I$ & Ne. of Se. of 20 & & $\mathrm{~N} 31^{\circ} \mathrm{E}$ & $2^{\circ} \overline{3} 0^{\prime}$ & & \\
\hline & 68 & XXVII & Se. of Se. of 25 & $\overline{\text { Winterset limestone }}$ & $\mathrm{N} 84^{\circ} \mathrm{W}$ & $9^{\circ} 35^{\prime} \mathrm{N}$ & & \\
\hline & & & & De Kalb limestone & $\begin{array}{l}\mathrm{N} 17^{\circ} \mathrm{W} \\
\mathrm{N} 84^{\circ} \mathrm{W}\end{array}$ & $\begin{array}{l}3^{\circ} 10^{\prime} \mathrm{W} \\
3^{\circ} 30^{\prime} \mathrm{N} \\
\end{array}$ & & \\
\hline Taylor ............ & 76 & $\mathrm{XXXV}$ & $\mathrm{Nw}$. of 21 & & $\mathrm{~N} 90^{\circ} \mathrm{E}^{-}$ & $\begin{array}{c}\text { From } 0^{\circ} \text { to } \\
3^{\circ} 30^{\prime} \text { in } 1 / 2-\mathrm{mi} \text {. }\end{array}$ & & \\
\hline \multirow[t]{2}{*}{ Page-................ } & 70 & $\mathrm{X} X \mathrm{XIX}$ & E. center of 36 & Essex & & & $\mathrm{N} 61^{\circ} \mathrm{W}$ & $45^{\prime}$ \\
\hline & 68 & $\overline{X X X I}$ & Sw. of Se. of 7 & Mine & $\mathrm{N} 57^{\circ} \mathrm{E}$ & $1^{\circ} \mathrm{S}$ & & \\
\hline \multirow[t]{2}{*}{ Fremont ...... } & 70 & XLIII & Ne. qr. of 14 & & $\mathrm{~N} 20^{\circ} \mathrm{E}$ & $3^{\circ} 45^{\prime} \mathrm{E}$ & & \\
\hline & $-67^{-}$ & XLII & Center of 13 & & $\mathrm{~N} 30^{\circ} \mathrm{W}$ & $3^{\circ} \mathrm{W}$ & & \\
\hline $\begin{array}{c}\text { Nebraska } \\
\text { City............. }\end{array}$ & & & & Clay pit & & & $\mathrm{N} 57^{\circ} \mathbf{E}$ & $3^{\circ} 30^{\prime}$ \\
\hline
\end{tabular}

* From estimates along a streteh of water. 
TABLE SHOWING JOINTS

\begin{tabular}{|c|c|c|c|c|c|c|c|}
\hline COUNTY & TwP. N. & RANGE, W & SECTION & LOCATION & FIRST SET & SECOND SET & THIRD SET \\
\hline \multirow[t]{2}{*}{ Madison ................ } & 76 & XXVII & Ne. of Nw. of 6 & $\begin{array}{c}\text { Bethany Falls ls. } \\
\text { Ladore shale }\end{array}$ & $\mathrm{N} 54^{\circ} \mathrm{E}$ & $\begin{array}{l}\mathrm{N} 58^{\circ} 42^{\prime} \mathrm{W} \\
\mathrm{N} 58^{\circ} 42^{\prime} \mathrm{W}\end{array}$ & $\mathrm{N} 12^{\circ} \mathrm{E}$ \\
\hline & 75 & XXVIII & Sw. of Nw. of 24 & & $\mathrm{~N} 53^{\circ} \mathrm{E}$ & $\mathrm{N} 32^{\circ} \mathrm{W}$ & $\mathrm{N} 4^{\circ} \mathrm{W}$ \\
\hline Cass......................... & 76 & $X \times X \times \Pi$ & Se. of Nw. of 9 & Spring creek & $\mathrm{N} 39^{\circ} 20^{\prime} \mathrm{E}$ & $\mathrm{N} 20^{\circ} 40^{\prime} \mathrm{W}$ & \\
\hline \multirow[t]{3}{*}{$\begin{array}{c}\text { Pottawat- } \\
\text { tamic } 75\end{array}$} & 74 & $X L$ & $\mathrm{Nw}$. of Nw. of 23 & Macedonia & $\begin{array}{c}\mathrm{N} 74^{\circ} \mathrm{E}, 83 \\
63,86,65 \\
65,80 \\
\text { Av. } 73^{\circ} 42^{\prime}\end{array}$ & $\mathrm{N} 52^{\circ} \mathrm{W}$ & $\begin{array}{c}\text { N31 }{ }^{\circ} \mathrm{E}, 42, \\
13,30, \\
13,30 . \\
\text { Ar. } 26^{\circ} 30^{\prime}\end{array}$ \\
\hline & & & Se. of Se. of 3 & $\begin{array}{c}\text { Carson } \\
. \\
\end{array}$ & $\begin{array}{l}\text { N48 }{ }^{\circ} \mathrm{E}, 69 \\
69,53,74 \\
\text { Av. } 62^{\circ} 36^{\prime}\end{array}$ & $\begin{array}{c}\mathrm{N} 15^{\circ} \mathrm{W}, 14, \\
3,15 . \\
\text { Av. } 11^{\circ} 45^{\prime}\end{array}$ & $\begin{array}{r}\mathrm{N} 1^{\circ} \mathrm{E} \\
43 \\
\text { Av. } 22^{\circ} \\
\end{array}$ \\
\hline & 76 & XLIV & West center of 26 & Croscent & $\begin{array}{l}\mathrm{N} 70^{\circ} \mathrm{E}, 55 \\
56,60,80^{\prime} \\
\mathrm{Av} .64^{\circ} 12^{\prime}\end{array}$ & $\begin{array}{c}\mathrm{N} 35^{\circ} \mathrm{W} \\
17,32,33 \\
30,25 . \\
\mathrm{Av} .28^{\circ} 42^{\prime}\end{array}$ & \\
\hline Montgomery ...- & 72 & XXXVחI & South center, 26 & & $\begin{array}{c}\mathrm{N} 61^{\circ} \mathrm{E} \\
54\end{array}$ & $\begin{array}{l}\mathrm{N} 35^{\circ} \mathrm{W} \\
-52 \\
\end{array}$ & $\mathrm{~N} 22^{\circ} \mathrm{E}$ \\
\hline Mills ...................... & 72 & XLIII & Sw. of Sw. of 22 & & $\mathrm{~N} 90^{\circ} \mathrm{E}$ & & $\mathrm{N} 35^{\circ} \mathrm{E}$ \\
\hline Decatur............. & 70 & XXVII & Sw. of Se. of 21 & & $\mathrm{~N} 58^{\circ} \mathrm{E}$ & & \\
\hline Taylor.................. & . 70 & $\mathrm{XXXV}$ & Nw. qr. of 21 & & & $\mathrm{~N} 23^{\circ} \mathrm{W}$ & $\mathrm{N} 21^{\circ} \mathrm{E}$ \\
\hline Page …................ & 70 & XXXIX & E. center of 36 & Essex, Preston ledge & $\mathrm{N} 68^{\circ} \mathrm{E}$ & $\mathrm{N} 3^{\circ} \mathrm{W}$ & \\
\hline \multirow[t]{3}{*}{ Fremont ............. } & 70 & XLII & Nw. of Se. of 26 & & $\mathrm{~N} 85^{\circ} \mathrm{E}$ & & $\begin{array}{l}\mathrm{N} 30^{\circ} \mathrm{E} \\
\mathrm{N} 40^{\circ} \mathrm{E}\end{array}$ \\
\hline & 67 & XLII : & Center of 13 & & & $\mathrm{~N} 80^{\circ} \mathrm{W}$ & $\mathrm{N} 38^{\circ} \mathrm{E}$ \\
\hline & 68 & XLI & Se. of Sw. of 33 & & & & $\mathrm{~N} 30^{\circ} \mathrm{E}$ \\
\hline Average & & & & & $\mathrm{N} 63^{\circ} 27.2^{\prime} \mathrm{E}$ & $\mathrm{N} 31^{\circ} 29.8^{\prime} \mathrm{W}$ & $\mathrm{N} 25^{\circ} 35.3^{\prime} \mathrm{E}$ \\
\hline
\end{tabular}

75The table of joints measured in Pottawattamie is from J. A. Udden, Geology of Poltawattamie Connty: Iowa Geol. Survey, Vol. XI, p. 268. 


\section{JOINTS}

The directions of joints in the rocks have also been measured in various places using the same instrument as that used in determining the dip. One set of joints, that of the largest cracks, is parallel to the Thurman-Wilson fault, and one is about at right angles to the fault and parallel to the direction of the minor folds. Where several records have been made close together, as in Udden's list in his report on Pottawattamie county, it is the average that appears in the outline map. In the diagram the general directions appear in the averages, and the irregularity appears in the scattering of the individual records.

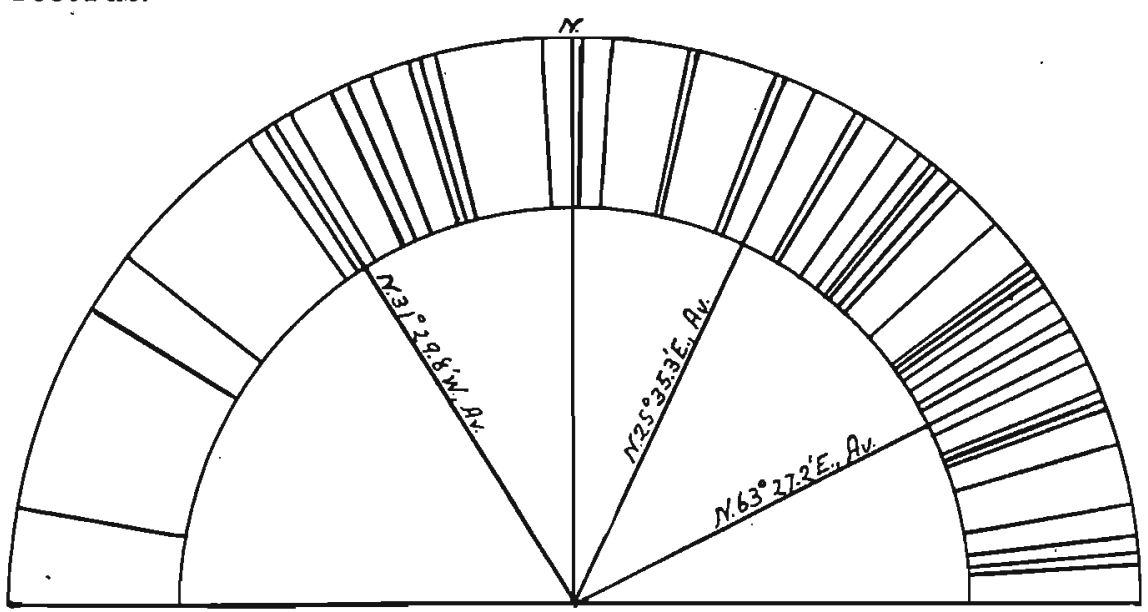

FIG. 52.-Diagram illustrating the directions of joints.

It is unfortunate that the drift conceals so much of the underlying rock as to make it impossible to work out all details of the gentle undulations that exist in the region. From what had been learned in the past the general position of the Nodaway coal had been determined. The latest important fact that has been ascertained is the reason for the absence of the Nodaway and Nyman seams from the area northwest of the Thurman-Wilson fault, except in a small area near Missouri river. This absence is due to the fact that the region to the north of the fault has been elevated and subjected to erosion, all of the Nodaway coal having been removed from that region, while to the south of the fault the region has been depressed and thus 


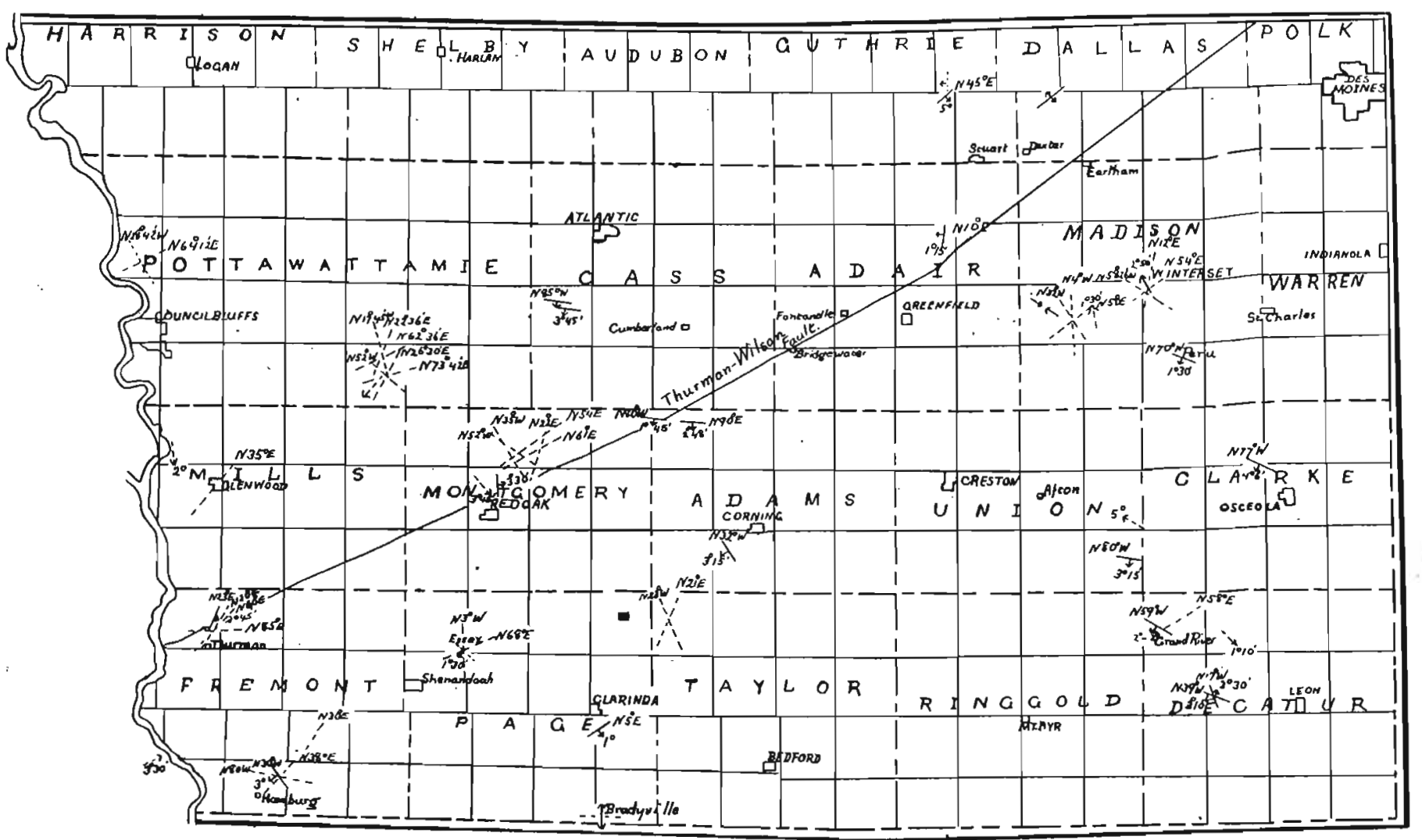

Outline map giving the location of measurements of dip and strike, and of directions of joints. The dip and strike are represented in the
usual way: (Strike) N45 $5^{\circ}$ (Dip) $1^{\circ} 30^{\prime}$ The dotted arrows represent general direction of dip without measurement. The dotted lines usual way: (Strike) $N 45^{\circ} \mathrm{W}$ (Dip) $I^{\circ} 30^{\prime}$ The dotted arrows represent general direction of dip without measurement. The dotted lines
represent directions of joints in the rocks. 
the seam has been protected from the general erosion, so that now the coal extends as far east as where the plane of the coal, rising toward the northeast, reaches the plane of erosion that existed when the glacial drift was laid down. Such important facts it is in the field of geological work to discover. Further details come within the province of the miner, who from borings determines the local variations that exist in the position and thickness of the seams. It is from such details where the Nodaway coal has been mined and where it may be mined in the future that additional data on levels can be accumulated and reduced to barometric elevations. This can lead to an isobathic map of the base of the Nodaway coal, and this in turn to more exact knowledge of the minor folds that cross the area.

A knowledge of the location of minor folds is of importance to any who may seek to ascertain whether oil and gas exist in the deeper strata in this region in sufficient quantity to be of commercial value. The above list of locations of anticlines and synclines, though not extensive, is sufficient to guide an experienced oil man in determining where he should first sink a test well. At Clarinda the Cherokee shale is about fifty feet above sea level, and at Winterset it is about six hundred and fifty feet above sea level. Neither oil nor gas in commercial quantities has been reported from such wells as have been put down ${ }^{78}$ and no seepage has been noted, though there are a few black limestone beds.

It is worthy of note that the deep well at Coin, though not quite along the axis of an anticline, is sufficiently well located to serve as a test well, although it is not very deep. It is re ported to have reached salt water; oil and gas are not reported. The well is 888 feet deep and was sunk as a test well for coal and gas." The bottom is about 680 feet above the Cherokee shale, which is here about 150 feet deeper than at Clarinda.

It is further worthy of note, from evidence presented by Dr. Alexander McCoy, with which evidence the data from southwestern Iowa are in agreement, that the Kansas City limestone grades into sandy shore deposits northward from Kan-

7aAt Nebraska City, Glenwood, Coin, Clarinda, Bedford, Leon, Stnnrt. p. 1158

$7 \rightarrow \mathrm{V}$, H. Norton, Underground Water Resources of Iowa: Iowa Geol. Survey, Vol. XXI, 
sas City toward southeastern Nebraska and southwestern Iowa; and that the western margin of this ancient sea is along a line of concealed granite hills or mountains ${ }^{78}$ revealed by well records as extending southwest into central and southern Kansas.

\section{The Areal Distribution in Iowa of the Divisions of the Missouri} Series.

In tracing the areal distribution of the divisions of the Missouri series main reliance must be placed on the limestone in the southwestern part of the state. Where shale is the basal member of the division the area may extend for a short distance beyond the area of the limestone member, but generally not far. Often it is impossible to state the exact position of the margin because of the presence of Dakota sandstone and of drift. Where the margins are thus concealed it is possible to represent only the approximate general boundaries.

South of the Thurman-Wilson Fault line.-The eastern margin of the Kansas City stage is distinctly marked most of the way from Osceola to a point north of Earlham, where it stops at the fault plane. The representation of the position beneath the drift from Osceola to Leon is approximate. At Leon the deep well and a preglacial valley lie east of the Missouri series, the front of the Kansas City stage thus bending westward of Leon. No trace of the Hertha limestone, at the base of the Kansas City stage, was found east of Weldon river near the state line.

The locations of the eastern fronts of the various subdivisions are certain along a number of the streams that cause reèntrants in these margins, as on North, Middle and South rivers in Madison county, Squaw creek in Clarke county, and Grand river in Decatur county. Bereath the drift in the divides it is only the general direction of the eastern margin of the De Kalb limestone that can be inferred from relation to exposures from near Middle river to Grand river.

likewise the eastern margins of the Lansing, Douglas and Shawnee stages may be satisfactorily determined in western

$78 \mathrm{~A}$ part of this information also comes from G. F. Condra of the University of Nebraska. Sae Jnhn L. Tiltnn. The Thurman-Wilson Fault through Southwestern Iowa, and its Bearing: The Journal of Geology, Vol. XXVII, p. 389 . 
Madison and eastern Adair counties, the chief difficulty there being to distinguish between the numerous limestones and' shales. Farther south the main reliance is upon the line of well records from Nebraska City to Leon, which indicates where the subdivisions come up beneath the drift; but only the general directions of the margins can there be located. Farther west, in Page and Fremont counties, the Tarkio and Preston beds of limestone help to locate the position of the base of the Wabaunsee stage along the valley sides. Below this plane the valleys are cut down into the Shawnee stage. This is true in Missouri river valley also.

With the exception of the region near Bridgewater the line maiking the eastern margin of the Nodaway coal is that of George L. Smith in his paper on "The Carboniferous Section of -Southwestern Iowa," to which frequent reference has been made. The eastern border of the Nodaway coal marks approximately the eastern margin of the Howard limestone, the baise of which, according to Beede and Rogers ${ }^{78}$ marks a division between two faunas.

North of the Thurman-Wilson fault line.-The limestone near Stuart and the Eureka coal seam in the western part of Adair county having been correlated with beds deep in strata of the Des Moines series, ${ }^{80}$ the eastern margin of the Missouri series is clearly farther to the west. See the map of the area near Staurt, Plate XXVII, also figures 53 and 54. In the record of the deep well at Atlantic ${ }^{81}$ there is no evidence whatever of the presence of the various limestone members of the Kansas City stage; and yet the Oread limestone is clearly located five miles to the south on Turkey creek, and again at Fox quarry northeast of Grant. Whatever is concealed beneath the Dakota sandstone and the thick drift of the region must lie between Atlantic and these two points.

A further inference that has a bearing is dependent on

\footnotetext{
79J. W. Beede and A. F. Rogers, Coal Measure Faunal Studies: Kansas Unir. Geol Survey, Vol. 9, pp. 345-346, 1908; also Hinds and Groene, Stratigraphy of the Pennsylvanian Series in Missouri, Missouri Bur. Mines, Bull. XIII, p. 183. 153,1922 .

81The record may be found in the following reports: p. 1121 .

Norton, Underground Water Resources of Iowa: Iowa Geol. Survey, Vol. XXI,

John L. Tilton, Geology of Cass County: Iowa Geol. Survey, Vol. XXVII, p. 257.
} 


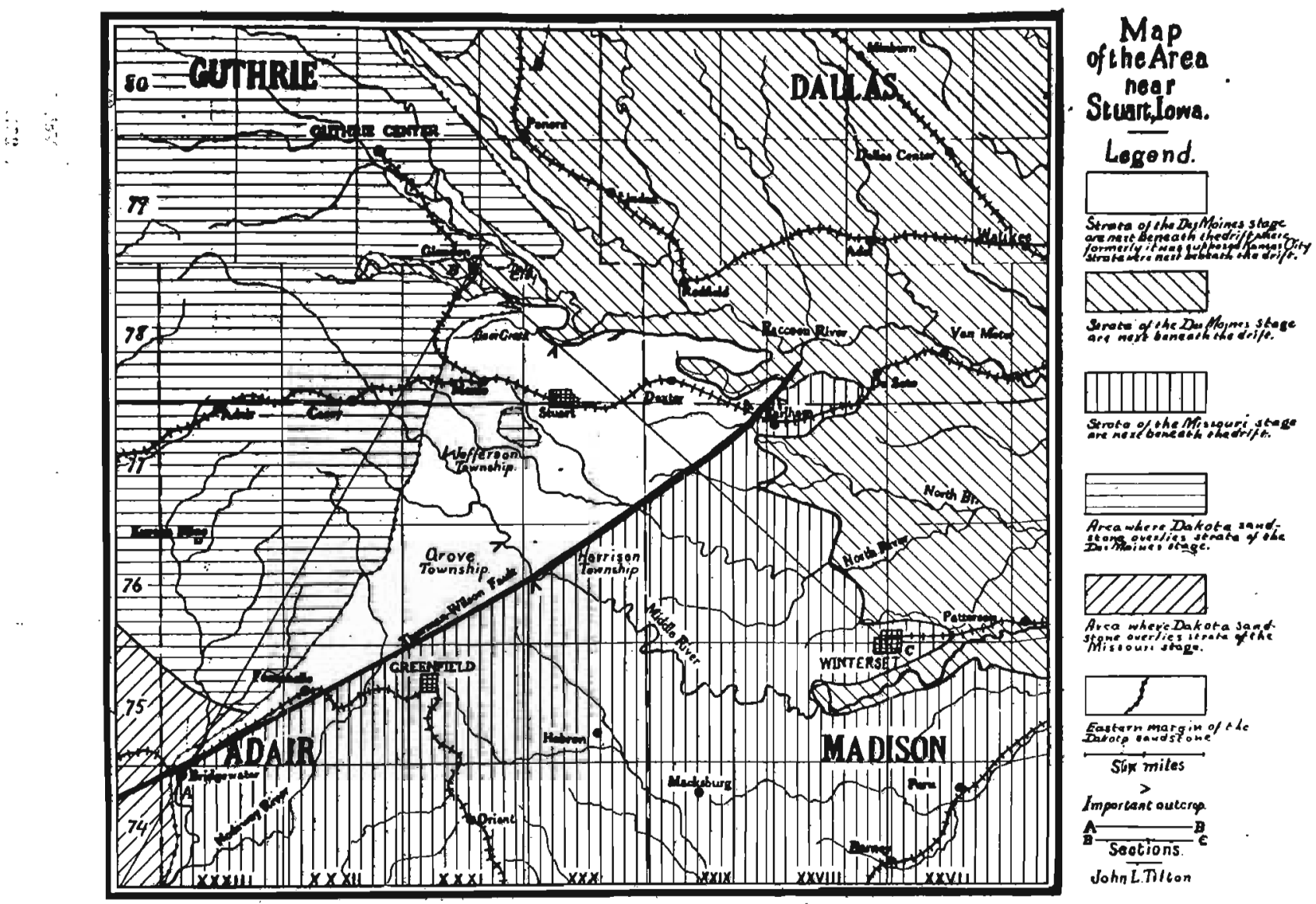

Map of the area near Stuart, showing distribution of the strata. 
changes in strata north of Kansas City, Missouri. Near Kánsas City the members of the Kansas City stage are as well or better developed than they are at Winterset and at Earlham; but to the northwest of Kansas City the strata grade into sand. stone and shale, toward the old shore line, so that in the deep well record at Forest City, half way between Kansas City and the Iowa state line, the Kansas City stage is represented by sandstone and shale ${ }^{82}$ instead of by limestone and shale. Thus

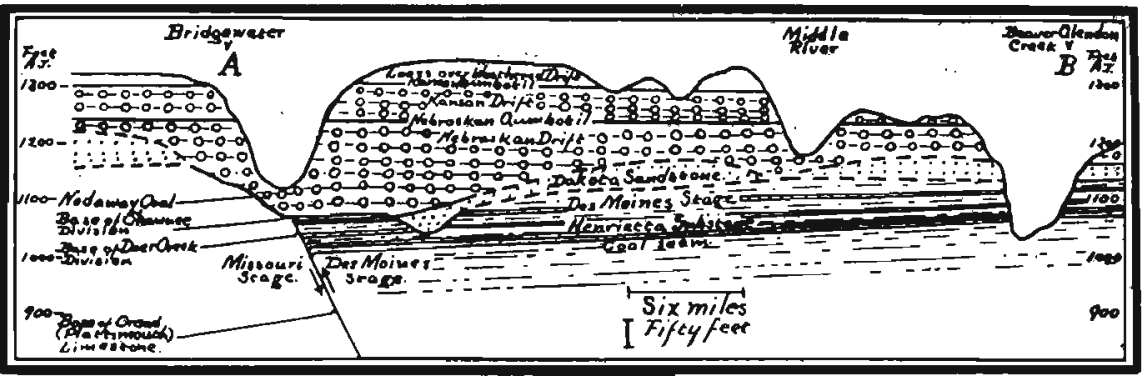

FIG. 53.-A Section from Bridgewater to Glendon, $A$ to $B$ on the map, Plate XXVII.

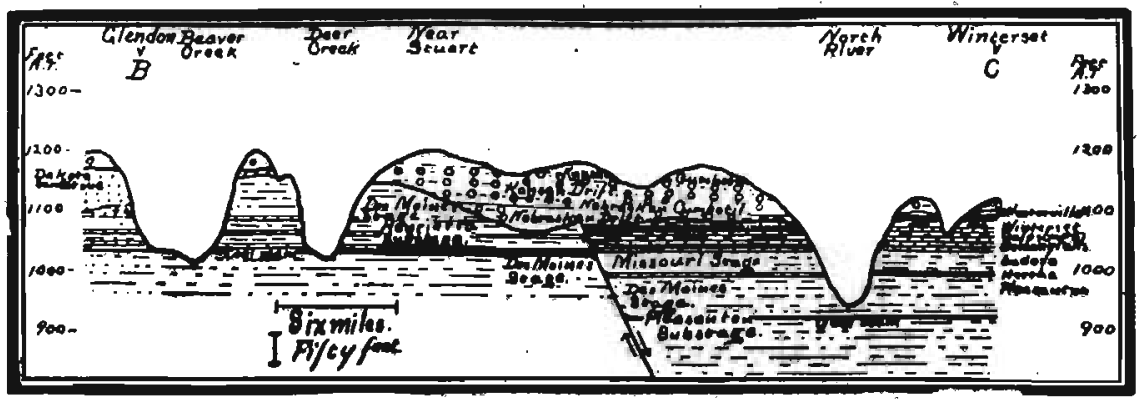

FIe. 54.-A Section from Glendon to Winterset, $\mathbf{B}$ to $\mathbf{C}$ on the map, Plate XXVII.

in Kansas City time the shore was not far away to the northwest and west. In northeastern Nebraska no outcrops of the Kansas City stage are recognized. The inference thus seems warranted that from Earlham toward the west shore conditions were more and more effective and that in the movements that gave us the Thurman-Wilson fault with accompanying erosion on the upthrow side these differing strata, from the conspicuous limestone beds at Earlham to the shales and sand-

82Dr. Alexander MfcCoy has reached this conclusion from the series of well records in eastern Kansas, and he presented his evidence to the writer when inquiring about the conditions in Iowa. The writer has studied the well records presented and has come to accept Doctor McCoy's conclusion. The evidence involves a different interpretation of the record of Doctor McCoy's conclusion. The evidence involves a different interpretation of the record of Series in Missouri, Missouri Bur. Geol. and Mines, Bull. XIII, pp. 215-239. 
stones farther west, were eroded away. The erosion has thrown the present margin of the strata back toward the west about thirty miles. Nevertheless, somewhere between the Oread limestone outcrop south of Atlantic and the Eureka coal mine in northwestern Adair county there must lie, below the Dakota sandstone and the thick drift in that region, all that now remains of this portion of the Lansing and Kansas City stages. These stages are therefore assigned areas that are consistent with these facts.

The trend of the eastern margin of the Oread limestone toward the northwest and west seems to justify the representation of a similar trend in the margin of the Lansing stage. This involves the correlation of the limestone beds at Crescent. These beds lack the distinctive characteristics of the Oread limestone and their characteristics are judged to be in accord rather with those of the Lansing stage.

The border line between the Lansing and Douglas stages is clearly south of Crescent, and hence south of the place on Mosquito creek where White found exposed strata that are now concealed. These he correlated with the limestone found at Crescent. $^{83}$ The northern margin of the Lansing stage is thus placed not far north of Crescent. The Lansing stage is also represented as extending south under the Missouri river deposits to the Thurman-Wilson fault, since the valley evidently has been cut below the level of the Oread limestone, which is exposedi sopth of Glenwopd and at Henton.

There is an absence of exposures of stratified rock along the river valley from Crescent to near Logan, where well records reveal a widely distributed bed of limestone, ${ }^{84}$ the position of which demands the following discussion.

Comparing Calvin's faunal list of fossils from the limestone at Logan, as reported by Shimek, with Udden's list for Crescent, in the report on Pottawattamie county, it is noted that Campophyllum torquium is reported at Logan but not at Crescent, that what is identified as Productus (Marginifera) longispinus is abundant at Logan but is wanting at Crescent, and

83C. A. White, Geology of Towa, Vol. I, p. 379, 1870.

84B. Shimek, Geology of Harrison and Monona Counties: Iowa Geol. Survay, Vol. XX, p. $301-302$. 
that Spiriferina, found at Logan, also is wanting at Crescent. On the other hand, Astrophyllum rude, found at Crescent, is absent at Logan. So also are Archeocidaris, the bryozoans, and Productus punctatus. The other brachiopods that are present at both places are also found throughout both the Des Moines and Missouri series (up to the Wabaunsee stage). Not only do the faunal lists disagree to this extent but the records of the sequence of strata ${ }^{85}$ also disagree, and the general dip of the strata places the limestone at Logan far below that at Crescent.

The next comparison is with the Kansas City stage, the beds of which, if present at all, lie beneath the Lansing stage. All the fossils named are reported here and there in the Kansas City stage either in Towa or Missouri, and they are also found in the Des Moines series and in all the other divisions of the Missouri series, unless it be Campophyllum torquium, which has an uncertain distribution. The number (eight) of $\mathbf{M a r}$ ginifera (Productus) longispina reported from near Logan especially attracts attention, for this shell is not found in abundance in the Missouri series, while Marginifera (Productus) muricata, a shell much like it, does occur in great abundance in parts of the Des Moines series. Imperfect specimens of the two may look very much alike. However, Marginifera longispina is not to be considered an index fossil ${ }^{86}$ of the Missouri

\footnotetext{
85For the record of the strata at Crescent see: J. A. Udden, Geology of Pottawattamie County: Iowa Geol. Survey, Vol. XI, p. 227. For the record of the strata near Logan see: C. R. Keyes, Coal Deposits of Southwestern Iowa: Iowa Geol. Survey, Vol. II, p. 437.

86Formerly it was thought in Iowa that Marginifera (Produetus) longispina was as truly an index fossil of the Missouri series as $\boldsymbol{M}$. muricata is of the Des Moines series, but literature with reference to $M f$. longiapina (and also $M$. wabashensis, a possible synonym) does not support that view.

Stuart Weller in Bulletin 153, U. S. Geological Surrer, lists Productus muricatus, $P$ longispinus and $P$. wabashensis as three distinct species and $P$. splendens as a synonym of $P$. longispinus.

George $H$. Girty in his Palaeontolngy of the Pennsplvanian of Missouri (Hinds and Greene, Stratigraphy of the Pennsy]panian Series of Missouri: Missouri Bur. Mines, XIII, 1915, table p. 303 and text) lists H. wabashensis as found in Cherokes shales of the Des Moines series, doubtful in the Henrietta, and present in all divisions of the Missouri series excepting the Wabrunsee stage. He also mentions $M$. muricata (Chonetes mesolobus, etc.) as restricted to the Des Moines group (series). (Idem., 281.)

In Iova A. G. Leonard lists Marginifera (Productus) longispina as found with 1 . muricata and Chonetes mesolobus close to Adel. H. Foster Bain names it as being found in the limestone north of Stuart, and Samuel Calvin mentions it among the fossils found near Logan in Harrison county. In the last two places it, was at the time supposed that the strata were in the Missouri series. As pxplained in this papor and in "The Strata 'near Stuart, Iowa," read before the Geological Socipty of America Decembar, 1921 it is now found that the read before the Geological Socipty of America, Decembar, 1921, it is now found that the
strats $\pi \mathrm{re}$ in the lower part of the Des Moines series. G. L. Smith in his earliest paper on "The Palaeontology and Stratigraphr of the Upper Carboniferous of Iowa" (Proceedings of the Iowa Academy of Science, Vol. XXII, 1915), nanies $P$. muricatus and $P$. longispinus as hoth found in the City Bluff shale. In a later naper (Jdem., XXV, 535. 1918) he comments on criticism for identification of $K$. muricata in the Forbes (Deer Creek) and City BTnff shale, and in the tahla that follows lists $M$. unbashensis as a synonym for $M r$. longispina. In his contributions published in 1916 (Idem., XXIII, 87) he had mentioned $M$, longispina as found near the Nyman coal, and $M$. wabashensis as found near Thurman. The locations at
} 
series for it is reported from both the Des Moines and the Missouri series.

Comparing the faunal list from Liogan with the faunal list from north of Stuart, ${ }^{87}$ it is noted that Fusulina (few at Logan) is not in the list from north of Stuart, and that Campophyllum likewise is absent; as are also Productus punctatus, Spirifer kentuckiensis and Phillipsia major, all of which are reported as being found in all of the subdivisions of both the Des Moines and Missouri series, except that Campophyilum has an uncertain distribution. Phillipsia major is listed as doubtful in the Henrietta formation. ${ }^{88}$ The character of the strata at Logan, their position with reference to the Missouri strata to the south, and with reference to the Des Moines strata near Stuart to the east, give evidence that the strata at Logan belong to the Des Moines series.

Following what seems to the writer the proper conclusion, the margin of the Des Moines series, where it disappears beneath the Lansing stage, extends from near Atlantic northwest and then west to not far north of Crescent, leaving the area to the north for the location of Des Moines strata. ${ }^{89}$

The above description presents the physical basis for the plane separating two faunal units, one including the Kansás City stage, the other including the strata from the top of the Kansas City stage to the top of the Oread limestone. ${ }^{20}$.

\footnotetext{
Thurman, at the Nyman coal and at the City Bluff beds are all in the Wabaunsee stage of the Missouri series, the division from which in Missouri Girty did not report that species.

F. B. Meek considered both $P$. splendens and $P$. wabashensis as synonyms of $P$. longispinus. ("Final Report of the U. S. Geological Survey of Nebraska," etc., 1872, 162.)

pinus. ("Final Report of the U. S. Geological Survey of Nebraska," etc., 1872, 162.)
C. A. White thought both $P$. muricatus and $P$. longispinus ranged "through the whole of the Carboniferous or Coal Measure series." (U. S. Geological Survey West of the 100 th Meridian. IV, 1877, 119 and 120.)

G. H. Girty in his report on the "Stratigraphy and Palaeontology of the Upper Car. boniferous Rocks of the Kansas Section," (Bulletin 211 of the U. S. Geological Survey, 1903), lists $\mathrm{Af}$. muricata as found not only in the Cherokee, Fort Scott, Labette and Parsons members of the Des Moines series but slso in the Deer Creek and Lecompton of the Missouri series, M. wabashensis he reports from twelve different horizons: two in the Des Moines series, nine in the Missonri series, and one in the Permian. 87Collected by Samuel Calvin; H. Foster Bain, Geology of Guthrie County: Iowa Geological Survey, Vol. VII, p. 447.

Note that the strata north of Stuart are corselated with strata deep down in the Des Moines series: John L. Tilton, The Strata near Stuart, Iowa: Bulletin of the Geological Society of America, Vol. 33 , p. 153, 1922. 88Hinds and Greere, Stratigraphy of the Pennsylvanian Series in Missouri, Missouri Bur. Mines, Bull. XIII, pp. 302-307.

80Hinds and Greene's report on, "The Stratigraphy of the Pennsylvanian Series in Missouri" mentions five places that suggest conditions related to a disconformity close to the Cement City beds. They also note that in Jackson and Clay counties "a thin bed of impure Cement City beds. They also note that in Jackson and Clay counties "a thin bed of impure
coal in places appears in the Cherryvale shale above the Winterset limestone. One and a coal in places appears in the Cherryvale shale above the Winterset limestone. One and a formity" (p. 128); and, while the report named doas not mention it, the upper part of the Winterset limestoné neax Bethany Falls, Missouxi, is eren more conspicuously fragmental than it is at Winterset. 90Idem., pp. 116 and 155.
} 
The Douglas stage is at the surface at Riverview Park north of Red Oak, at Fox quarries in Cass county, and on Turkey creek north of Lewis. Its northern border lies somewhat north of these points, and then curves into a direction approximately west to near Council Bluffs and then south along the Missouri bluffs to the Thurman-Wilson fault. The strata that used to outcrop near Malvern are now concealed, but the excellent description of them and their fossil content that Udden ${ }^{91}$ prepared clearly identifies them with the beds about two miles southwest of Glenwood, at the railroad bridge over Keg creek. The Douglas stage is therefore represented as extending southward past Malvern to the fault line. The Douglas stage is also present in a narrow strip along the bluffs south of Glenwood to the Thurman-Wilson fault.

The Shawnee stage is well represented at Stennett in. Montgomery county. With these beds are correlated the beds at Carson, Macedonia ${ }^{22}$ and Henderson. Likewise north of the fault there is an area northeast of Thurman and around Tabor which contains coal that Smith $^{93}$ correlates with the Nodaway seam. Hence there is here represented an area of the uneroded strata of the Shawnee stage.

91J, A. Udden, Geology of Mrills and Fremont Counties: Iowa Geological Survey, Vol. XIII, p. 157 .

02Thus aggreeing with Udden: J. A. Udden, Geology of Pottawattamie County: Iowa Geol. Survey, Vol. XI, p. 230; but I cannot accept his correlation of the beds at Macedonia with those at Crescent, which is supported neither by sequence in character of the beds, nor by fossil content.

93George L. Smith, Carboniferous Section in Southwestern Iowa: Iowa Geol. Survey, Vol. XIX, p. 645 
